GUSTAVO FERREIRA DE ALMEIDA

Sementes oleaginosas na alimentação de vacas em lactação

Pirassununga, SP

2014 
GUSTAVO FERREIRA DE ALMEIDA

\section{Sementes oleaginosas na alimentação de vacas em lactação}

Dissertação apresentada ao Programa de PósGraduação em Nutrição e Produção Animal da Faculdade de Medicina Veterinária e Zootecnia da Universidade de São Paulo, para obtenção do título de Mestre em Ciências

\section{Departamento:}

Nutrição e Produção Animal

\section{Área de Concentração:}

Nutrição e Produção Animal

\section{Orientador:}

Prof. Dr. Francisco Palma Rennó

De acordo:

Orientador(a)

\section{Pirassununga}

2014 
Autorizo a reprodução parcial ou total desta obra, para fins acadêmicos, desde que citada a fonte.

DADOS INTERNACIONAIS DE CATALOGAÇÃO-NA-PUBLICAÇÃO

(Biblioteca Virginie Buff D’Ápice da Faculdade de Medicina Veterinária e Zootecnia da Universidade de São Paulo)

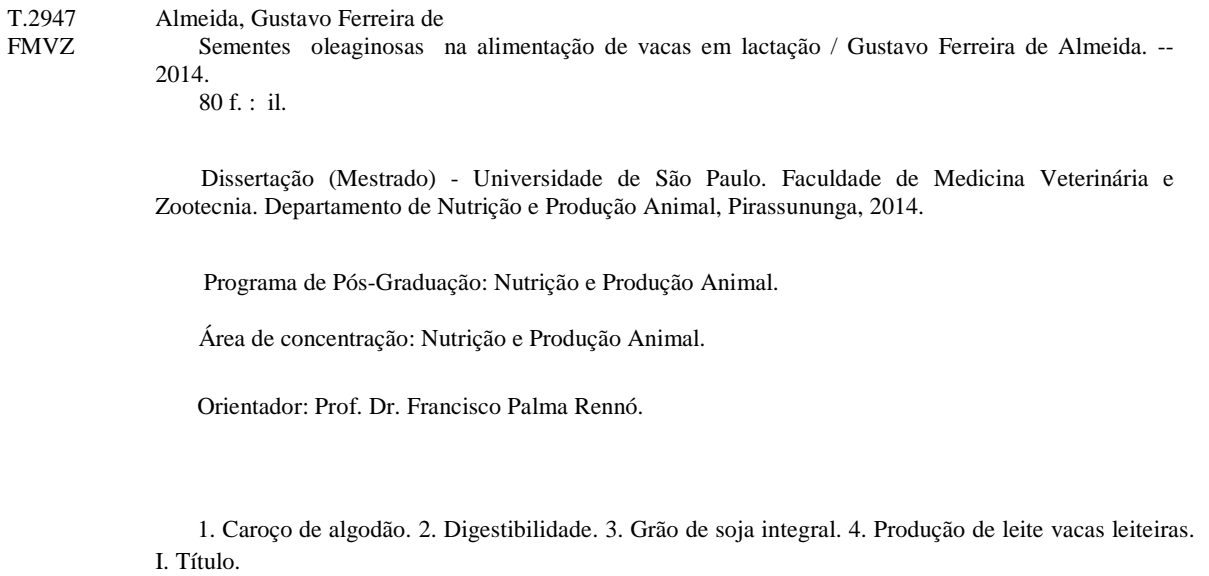

1. Caroço de algodão. 2. Digestibilidade. 3. Grão de soja integral. 4. Produção de leite vacas leiteiras. I. Título. 


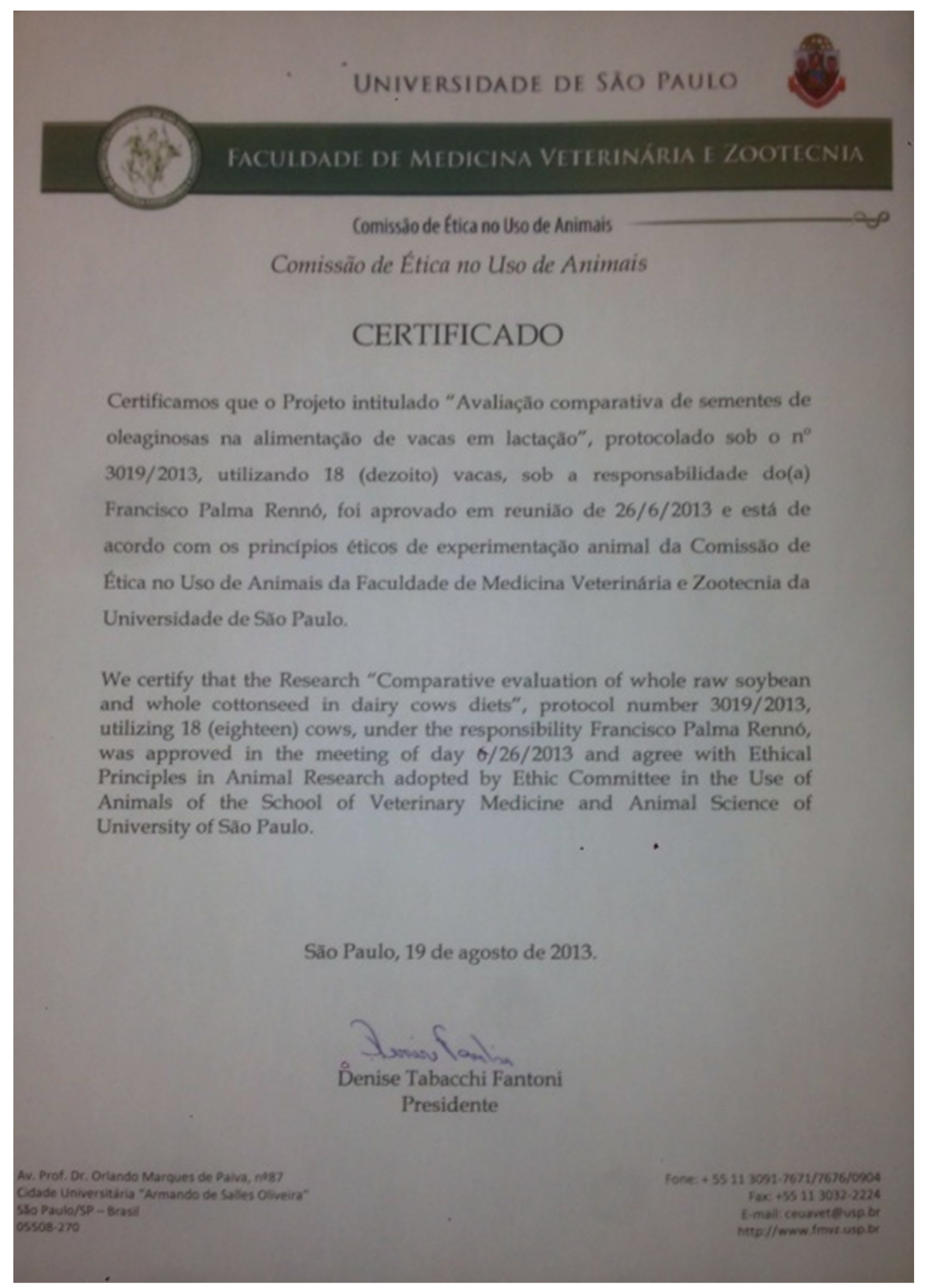




\section{FOLHA DE AVALIAÇÃO}

Autor: ALMEIDA, Gustavo Ferreira

Título: Sementes oleaginosas na alimentação de vacas em lactação

Dissertação apresentada ao Programa de PósGraduação em Nutrição e Produção Animal da Faculdade de Medicina Veterinária e Zootecnia da Universidade de São Paulo, para obtenção do título de Mestre em Ciências

Data:

\section{Banca Examinadora}

Prof. Dr.:

Instituição: Assinatura:

Prof. Dr.:

Instituição:

Assinatura:

Prof. Dr.:

Instituição: Assinatura: 


\section{DEDICATÓRIA}

Ao grande homem, saudoso Tio Carlão, retireiro que antes da alvorada, sempre me recebeu com um gigantesco abraço e um bom copo de café doce como seu sorisso e aos milhares de outros trabalhadores rurais que independente das adversidades, dia após dia, atravessam suas vidas na mais nobre e fundamental das atividades humanas, a produção de alimento. A vocês, meu máximo respeito.

A memoria do meu pai, grande Zé Boi e a VIDA da minha linda mãe Tânia.

Dedico este trabalho do fundo do meu coração 


\section{AGRADECIMENTO}

À Universidade de São Paulo, a Faculdade de Medicina Veterinária e Zootecnia, e ao Departamento de Nutrição e Produção Animal pela oportunidade de realização deste curso;

Ao Conselho Nacional de Desenvolvimento Cientifico e Tecnológico (CNPq), pela concessão da bolsa de estudo;

Ao muito mais que orientador Professor Dr. Francisco Palma Rennó, pela oportunidade dada ao me aceitar como orientado, pelos ensinamentos dos mais diversos tipos ao longo desse tempo, e pelo TOTAL suporte durante todas as etapas desse projeto. Foi joia ter conduzido este trabalho junto ao senhor, sem duvida, um divisor de aguas em minha vida.

Agradeço ao meu grande amigo Mariano Etchichury e a minha irmazinha Aline Ambrogi por ter feito com que eu acreditasse ser capaz de realizar este sonho.

Agradeço a minha mãe Tania pelo amor incondicional. Chegamos mais longe do que qualquer professora do primário poderia esperar mamãe. Obrigado por junto ao meu pai, ter me dado esta educação estilo Campestre.

Ao meu muito amado irmão de sangue, o famosíssimo Zé galinha, obrigado pelo companheirismo de alta qualidade ao longo de mais uma jornada.

Aos meus amigos de Campestre os quais estão comigo por mais de um quarto de século de amizade, viva a turma do VIRA O SANTO, e a tudo mais que amo em minha terra.

Aos meus irmãos adegueanos de Ouro Preto, aprendizados para uma vida, Cultura amizade e cachaça hoje e para todo sempre.

As minhas meninas da Puc Poços, Paula, Andreza, Nara e Ana Paula vocês são um presente em minha vida. Amo vocês pra sempre.

Aos meus professores da graduação, Domingos, Claudia e Andreia, que me proporcionaram a base para conseguir ser melhor a cada dia.

Agradeço aos meus amigos Jefferson e Rafael por terem me acolhido em sua casa e coração, obrigado pelas farras, conversas e muitos ensinamento. Vocês mesmo quando distantes fisicamente nunca se negaram a estender suas mãos gordinhas e bondosas para me ajudar. Para vocês uma palavra, Gratidão.

Meu mais profundo agradecimento aos meus outros irmãos de republica que também foram A MELHOR EQUIPE DE TRABALHO QUE EU PODERIA TER ENCONTRADO NO MUNDO, Tiago Del Valle, meu grande amigo, como eu sou feliz por ter tido a sorte de ter um companheiro de mestrado com tantas qualidades quanto você. Trabalhamos dois anos juntos e mesmo morando na mesma casa, nunca consegui te tirar do serio ao menos uma vez, realmente eu acho que isso deve ser uma tarefa impossível. Obrigado ao Elmeson, de Novo Cruzeiro para o mundo, Mineirinho não tem preguiça nem de trabalhar, imagina se ia ter pra fazer farra com a gente? Meu muito obrigado a melhor pessoa de todo Centro Oeste, Pablo 
Gomes de Paiva, que cara joia você é. Hoje eu vejo nos 4 como uma mistura de quarteto fantástico com os trapalhões. Pode passar mais muitos anos e eu nunca vou me cansar de contar e cantar nossas inúmeras historias e presepadas. Com vocês ao meu lado a jornada foi mais fácil e com muita risada todo dia. Somos hoje como uma família.

Aos demais pós-graduandos da equipe, Rodrigo Kumixão e Gustavo "xará" foi muito bom trabalhar com duas pessoas tão gente fina como vocês, vocês são muito joia. Rodolfo Badá, por ser esta pessoa impar e agradável, que considero muito. Obrigado Filipe "Gaucho" Zanferari, por sempre me ajudar das mais diversas formas. Obrigado Vitor Betero, Cybele Araújo (Cibela), Taìssa Canaes, Jose Esler, Lenita, Thiago Vendramini, Tiago Henrique Silva, Caio Takya, foi enriquecedora nossa convivência.

Aos nossos inestimáveis IC`s principalmente aos que me ajudaram diretamente; Mariana, Guilherme, Artur, Victor, Dado, Barrosa, extremamente essenciais neste projeto. Com vocês eu aprendi a ensinar e a aprender. Tenho por vocês um inestimável apreço e grandessíssima esperança.

A todos os estagiários que me auxiliaram na realização deste trabalho, em especial ao meu filho vermelho e colombiano, Jesus Cardoso, ao Andreas "colombinha" Vargas e ao Gabriel Costa Rica, foi uma lição de vida gigantesca ter tido a oportunidade de poder ter trabalhado junto a vocês.

Meu muito obrigado ao Laboratório Pesquisa em Bovinos Leiteiros e todos os seus funcionários, Tio Carlão (in memorian), Diogão meu grande amigo e parceiro, Toco, Lenon, Lucas, Felipe, Shmith vocês são nota 10. Gostaria de agradecer em especial a vida do Paulo Highlander e seu irmão Jota, melhor família de Pirassununga.

Obrigado especial a quem foi minha mãe nessa cidade, Dona Dalva eu te amo !

Aos meus colegas de pós graduação, pelas festas, farras e estudos.

A minha querida Ana Paula pelas ótimas prozas e por sua indispensável ajuda.

Aos professores do departamento de Nutrição e Produção Animal da FMVZ-USP Por todos os ensinamentos e pelo convívio.

Aos funcionários do VNP, que sempre se mostraram dispostos a me ajudar.

Aos demais funcionários da Prefeitura do Campus Administrativo de Pirassununga - PCAPS

A todos que ajudaram direta ou indiretamente a realização deste trabalho meus sinceros agradecimentos. 
"Eu quase que nada não sei. Mas desconfio de muita coisa."

Guimarães Rosa

"O conhecimento serve para encantar as pessoas, não para humilhá-las."

Mario Sergio Cortella

"Tu que não tiveste a felicidade Deixa a cidade e vem conhecer

Meu sertão querido, meu reino encantado

Meu berço adorado que me viu nascer"

Tião Carreiro 


\section{RESUMO}

ALMEIDA, G. F. Sementes oleaginosas na alimentação de vacas em lactação. [Oilseeds in dairy cow diet]. 2014. 80 f. Dissertação (Mestrado em Ciência) - Faculdade de Medicina Veterinária e Zootecnia, Universidade de São Paulo, Pirassununga, 2014.

Objetivou-se avaliar a inclusão de grão de soja cru e integral ou caroço de algodão na dieta de vacas em lactação e seus efeitos sobre o consumo e digestibilidade total da matéria seca e nutrientes, fermentação e síntese de proteína microbiana ruminal, produção e composição do leite, metabólitos sanguíneos, balanço de energia e de nitrogênio. Foram utilizadas 18 vacas da raça Holandesa, multíparas, com produção de leite média de 32,22 Kg/dia, com peso médio de 585,2 $\pm 54,2 \mathrm{~kg}$ e média de $133,0 \pm 53,1$ dias em lactação, sendo três vacas canuladas no rúmen e utilizadas para mensuração das variáveis ruminais. Os animais foram distribuídos aleatoriamente em seis quadrados latinos 3x3, balanceados e contemporâneos, de acordo com as seguintes dietas: 1) Controle, sem a inclusão de sementes oleaginosas; 2) Grão de soja, com a inclusão de $12 \%$ na MS da dieta 3) Caroço de algodão, com a inclusão de $12 \%$ na MS da dieta. Foi observado redução no consumo de matéria seca e carboidratos não fibrosos nos animais suplementados com sementes oleaginosas em relação aos que consumiram dieta controle e maior consumo de matéria seca, proteína bruta, extrato etéreo e carboidratos não fibrosos nos animais alimentados com grão de soja em relação aos que se alimentaram com caroço de algodão. Observou-se maior consumo e digestibilidade do extrato etéreo nas vacas que consumiram sementes oleaginosas. As dietas utilizadas não influenciaram a produção e composição do leite e a síntese de proteína microbiana ruminal. Os animais alimentados com caroço de algodão apresentaram maiores valores de $\mathrm{pH}$ ruminal que os que se alimentaram com inclusão de grão de soja e dieta controle, que não diferiram entre si. A concentração de $\mathrm{N}-\mathrm{NH}_{3}$ ruminal foi menor para as vacas que consumiram grão de soja em relação às vacas alimentadas com a dieta controle e com inclusão de caroço de algodão, que não diferiram entre si. As concentrações de colesterol total e HDL foram maiores para as vacas alimentadas com dietas contendo suplementação com sementes oleaginosas em relação as controle. Foi observado maior consumo e excreção fecal de nitrogênio dos animais alimentados com grão de soja do que com caroço de algodão. Também houve maior consumo de energia líquida de lactação e balanço de energia para as vacas que alimentadas com grão de soja em relação ao caroço de algodão. A inclusão de $12 \%$ de grão de 
soja ou caroço de algodão na MS das dietas de vacas em lactação altera o consumo e o metabolismo, sem afetar o desempenho produtivo.

Palavras-chave: Caroço de algodão. Digestibilidade. Grão de soja integral. Produção de leite vacas leiteiras. 


\begin{abstract}
ALMEIDA, G. F. Oilseeds in dairy cow diet. [Sementes oleaginosas na alimentação de vacas em lactação]. 2014. 80 f. Dissertação (Mestrado em Ciência) - Faculdade de Medicina Veterinária e Zootecnia, Universidade de São Paulo, Pirassununga, 2014.

The objective of this study was to determine the effects of feeding whole raw soybeans or whole cottonseed on nutrient intake and total tract digestibility, rumen fermentation and microbial protein synthesis, milk yield and composition, blood metabolites and nutrient balance. Eighteen Holstein multiparous cows, three of which were ruminally cannulated, with average milk yield of $32.22 \mathrm{~kg} \mathrm{~d}^{-1}$, average body weight of $585.2 \pm 54.2 \mathrm{~kg}$ and average DIM of $133.0 \pm 53.1$. The animals were used in $3 \times 3$ Latin square design experiment with $21-\mathrm{d}$ periods, and assigned in each square according DIM and milk yield. Cows were randomly distributed to the following treatments: 1) control, without addition of oilseeds; 2) Soybean, with inclusion of $12 \%$ of whole raw soybeans in DM basis of total diet; 3) Cottonseed, with inclusion of $12 \%$ of whole cottonseed in DM basis of total diet. Cows fed with cottonseed presented higher ruminal $\mathrm{pH}$ than cows fed with whole raw soybeans or control. The ruminal $\mathrm{N}-\mathrm{NH}_{3}$ concentration was decreased when cows were fed whole raw soybeans and control. Total cholesterol and HDL were higher for cows fed diets containing oilseeds when compared with cows fed control. Higher nitrogen intake and fecal excretion were observed when cows received whole raw soybeans than fed whole cottonseed. Moreover, higher $\mathrm{NE}_{\mathrm{L}}$ intake and energy balance were observed for cows fed whole raw soybeans when compared with cows fed whole cottonseed. The inclusion of $12 \%$ (DM basis of diet) of whole raw soybeans or whole cottonseed alters nutrient intake and metabolism, without affect the productive performance.
\end{abstract}

Key words: Cotton seed. Dairy cows. Soybean. Digestibility. Milk yield. 


\section{LISTA DE TABELAS}

Tabela 1 - Composição bromatológica dos ingredientes das dietas experimentais...............39

Tabela 2 - Ingredientes e composição quimico bromatológica dos concentrados ...............40

Tabela 3 - Ingredientes e composição químico bromatológica das dietas ...........................41

Tabela 4 - Consumo e digestibilidade aparente total da matéria seca e dos nutrientes de vacas lactantes alimentadas com inclusão de sementes oleaginosas ou não .......51

Tabela 5 - Parâmetros de fermentação ruminal de vacas lactantes alimentadas com inclusão de sementes oleaginosas ou não .....................................................................54

Tabela 6 - Síntese de proteína microbiana ruminal de vacas lactantes alimentadas com inclusão de sementes oleaginosas ou não

Tabela 7 - Produção e composição do leite de vacas lactantes alimentadas com inclusão de sementes oleaginosas ou não 63

Tabela 8 - Balanço de energia de vacas lactantes alimentadas com inclusão de sementes oleaginosas ou não 66

Tabela 9 - Balanço de nitrogênio de vacas lactantes alimentadas com inclusão de sementes oleaginosas ou não 68

Tabela 10 - Metabólitos plasmáticos de vacas lactantes alimentadas com inclusão de sementes oleaginosas ou não 70 


\section{LISTA DE FIGURAS}

Figura 1 - Efeito das dietas experimentais sobre o $\mathrm{pH}$ ruminal, nos diferentes

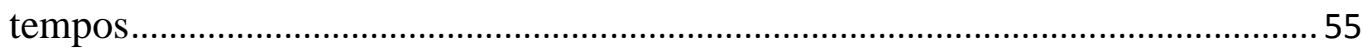

Figura 2 - Efeito das dietas experimentais sobre a concentração de N-NH3 ruminal,

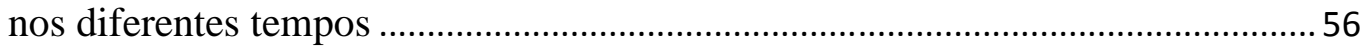

Figura 3 - Efeito das dietas experimentais sobre a produção de acido acético

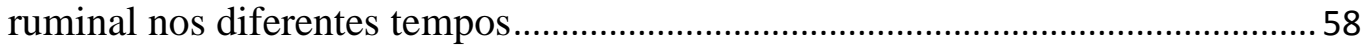

Figura 4 - Efeito das dietas experimentais sobre a produção de ácido propiônico ruminal nos diferentes tempos.

Figura 5 - Efeito das dietas experimentais sobre a produção de acido butirico ruminal nos diferentes tempos

Figura 6 - Efeito das dietas experimentais sobre a produção total de ácidos graxos de cadeia curta nos diferentes tempos 


\section{SUMÁRIO}

1 INTRODUÇÃ

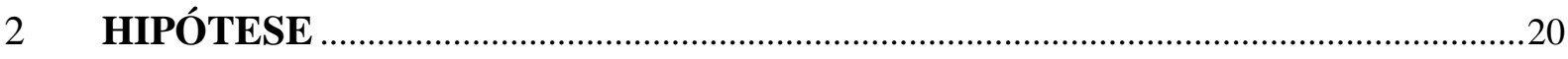

3 OBJETIVOS

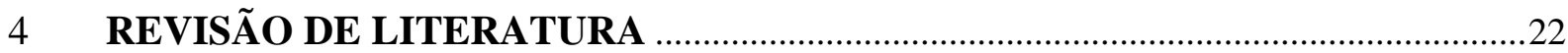

4.1 SEMENTES OLEAGINOSAS NA ALIMENTAÇÃO DE VACAS LEITEIRAS .........22

4.2 CAROÇO DE ALGODÃO NA ALIMENTAÇÃO DE VACAS LEITEIRAS ................23

4.2.1 Consumo e digestibilidade aparente total ....................................................................24

4.2.2 Fermentação e síntese de proteína microbiana ruminal .....................................................26

4.2.3 Produção e composição do leite ……………………………………………………......2

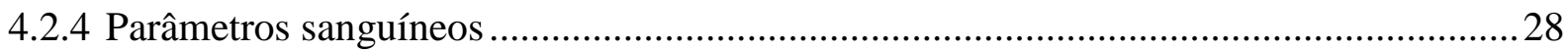

4.3 GRÃO DE SOJA NA ALIMENTAÇÃO DE VACAS LEITEIRAS ………………......29

4.3.1 Consumo e digestibilidade aparente total ................................................................ 30

4.3.2 Fermentação e sintese de proteina microbiana ruminal ..................................................... 32

4.3.3 Produção e composição do leite ……………………………………………………....33

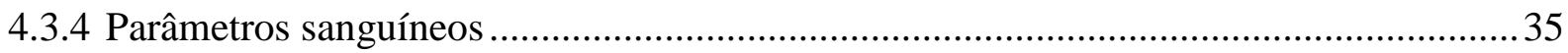

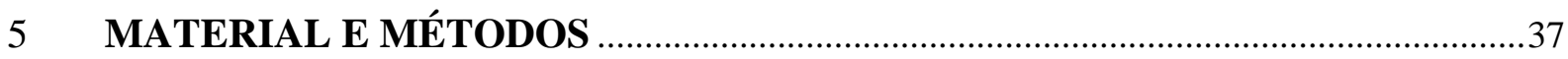

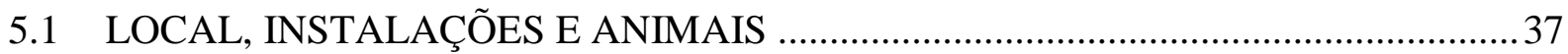

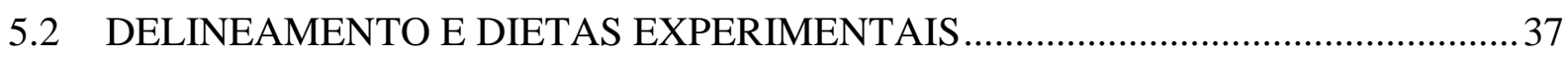

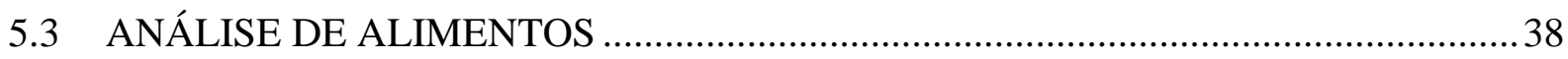

5.4 DIGESTIBILIDADE APARENTE TOTAL ……………………………………....42

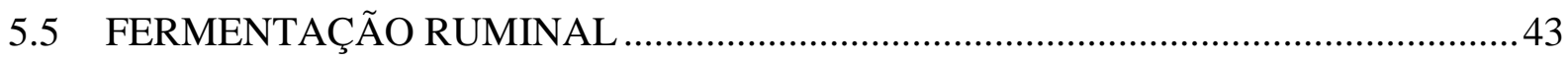

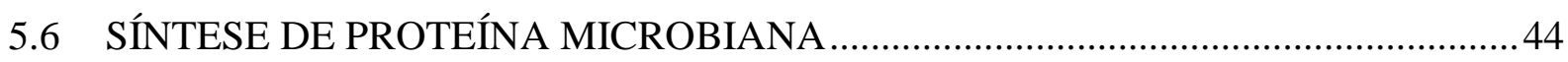

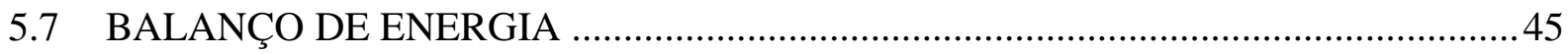

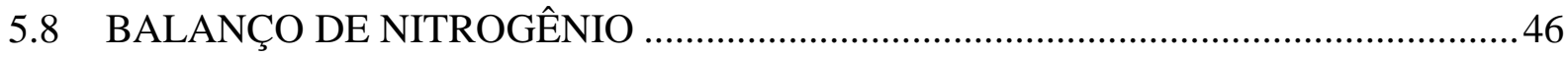

5.9 PRODUÇÃO E COMPOSIÇÃO DO LEITE …………………………………….......

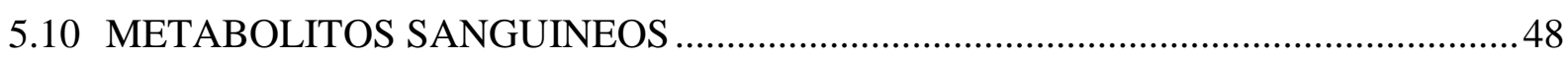

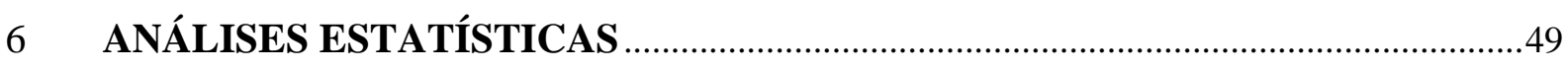

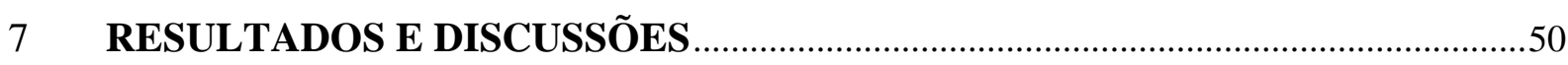

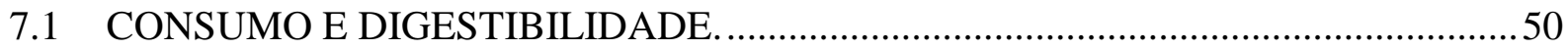

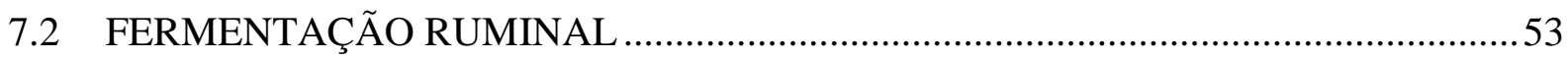

7.3 SINTESE DE PROTEINA MICROBIANA RUMINAL ...............................................60 


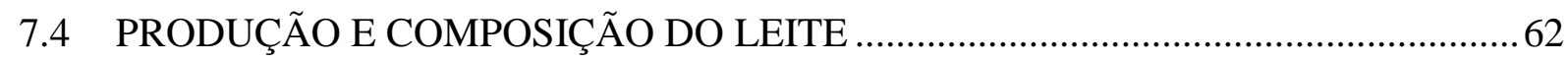

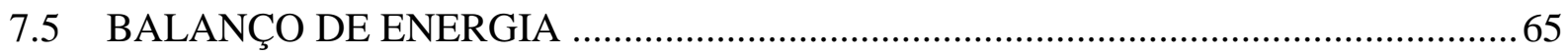

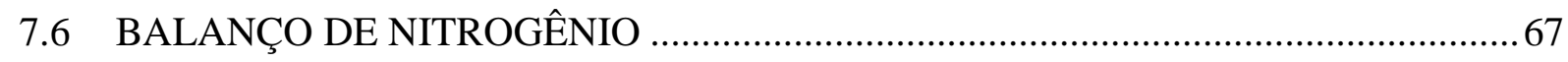

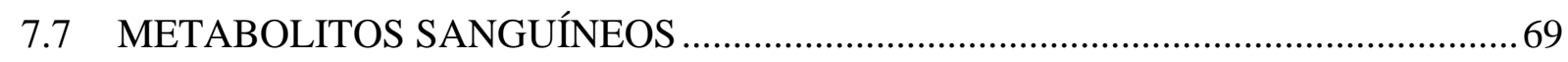

8 CONCLUSÃO

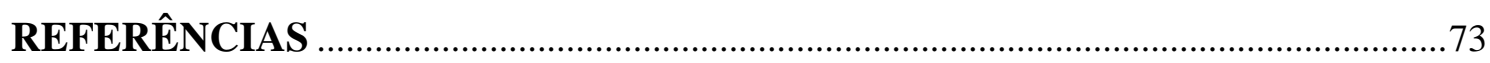




\section{INTRODUÇÃO}

Os custos com a alimentação correspondem a grande parte do custo operacional da produção leiteira. A utilização de alternativas a alimentos concentrados tradicionais na alimentação de ruminantes, como o milho e farelo de soja são importantes, pois estes dois alimentos, apesar de seu alto valor nutritivo para vacas leiteiras, possuem valor de mercado variável e muitas vezes se tornam opções caras, visto que são cereais utilizados na nutrição humana e animal.

Nesse sentido, o uso de alimentos alternativos é opção para tentar reduzir as variações de preço de fontes proteicas como farelo de soja e do milho, este último utilizado em maior proporção no preparo das dietas. Uma opção para tal seria a inclusão de fontes de lipídeos na alimentação de vacas leiteiras que tem sido muito utilizado por possibilitar o atendimento de maior demanda energética, melhorar a eficiência energética de produção de leite, fornecer ácidos graxos essenciais e melhorar a absorção de compostos lipossolúveis.

Uma maneira de acrescentar lipídeos na alimentação de vacas leiteiras é através da inclusão de sementes oleaginosas na dieta. A avaliação do desempenho animal com esses ingredientes na dieta são imprescindíveis para adequada recomendação, de forma a não trazer prejuízo ao sistema de produção. Dentre as várias sementes, o grão de soja cru e integral e o caroço de algodão têm grandes vantagens para serem utilizado neste propósito, pois são produzidos em grande escala.

Porém, esta avaliação nem sempre é simples, vários componentes do custo devem ser considerados como a logística, transporte, descarga e armazenamento, composição nutricional, além do resultado que se espera com o produto em questão. Uma possível vantagem da inclusão de sementes oleaginosas na alimentação de vacas em lactação é a maior flexibilidade de formulação das dietas, pela maior disponibilidade e diversidade de alimentos, além disso, alguns produtos podem conter ingredientes especiais complementares aos já existentes, que proporcionam ajuste fino da dieta, possibilitando melhor desempenho dos animais. Outra vantagem refere-se a utilização de alimentos que dispensem qualquer tipo de processamento (como a moagem e a tostagem), pois já são comercializados na forma adequada de uso, o que representa economia de mão de obra e energia (BARLETTA, 2010).

A alternativa tradicional é o caroço de algodão, uma das plantas mais utilizadas pela humanidade, desde a confecção de vestimentas, nutrição animal e humano à produtos com 
grande grau de industrialização. O algodão é planta herbácea rica em proteína, lipídeos (óleo), e carboidrato na forma de celulose (línter e pluma), podendo substituir em partes tanto a soja, como o milho e as forrageiras. A possibilidade de utilização de caroço de algodão na alimentação de vacas leiteiras é ampla, para animais de diferentes níveis de produção e fases de lactação. O caroço de algodão pode ser utilizado em até 15,0\% na matéria seca da dieta sem alterar drasticamente a digestão da fibra, especialmente pela lenta liberação dos ácidos graxos no rúmen (MOORE; SWINGLE; HALE, 1986).

Outra possibilidade seria a utilização de grão de soja, que entre as diferentes fontes de proteína e lipídeos, se destaca pela grande disponibilidade e custo compatível com seu rico conteúdo em nutrientes. A utilização do grão de soja cru ou não processado na alimentação de ruminantes não é recente. Entre as vantagens de uso do grão de soja integral como fonte de lipídeos pode ser citada a lenta liberação deste no rúmen, impedindo possível perda de digestibilidade de fibra pelo efeito negativo que ácidos graxos insaturados prontamente disponíveis no rúmen podem causar nas bactérias fibrolíticas (COPPOCK; WILKS, 1991; PALMQUIST, 1991). Desta forma, o grão de soja tem sido utilizado na alimentação de ruminantes como fonte de proteína, e lipídeos, e por também apresentar fibra de alta digestibilidade, e com efetividade mediana quando comparado com forragens, mas superior a de outros alimentos concentrados. O grão de soja também se destaca pelo elevado valor de ácidos graxos insaturados e pela grande aceitação pelos animais (PALMQUIST, 1978; PALMQUIST, 1991; RABELLO et al., 1996; PALMQUIST; MATTOS, 2006) Além disto, a soja é bastante cultivada nas mais importantes bacias leiteiras do Brasil, especialmente nos estados de Minas Gerais, São Paulo, Paraná e Goiás, viabilizando a utilização do grão de soja na alimentação animal (RENNÓ et al., 2009).

Muitos produtores são resistentes a utilização de determinados tipos de alimentos devido ao pouco conhecimento em relação a estes. Resultados recentes de estudos que avaliaram a inclusão de grão de soja cru e integral na alimentação de vacas leiteiras indicam o grande potencial de sua utilização como fonte de energia, proteína e ácidos graxos. Assim, é possível que o grão de soja, assim como o caroço de algodão sejam utilizados não somente como fonte de proteína em dietas para vacas leiteiras, substituindo o farelo de soja, mas também como eventual substituto do fubá de milho.

Desta forma, a realização do presente estudo vai ao encontro da necessidade de se ter mais informações a respeito da utilização do grão de soja cru e integral e do caroço de 
algodão em condições semelhantes as encontradas nas fazendas brasileiras, a fim de contribuir com informações que possam ser úteis na tomada de decisão pelos produtores de leite. 


\section{HIPÓTESE}

A hipótese científica a ser avaliada neste experimento sugere que a inclusão de $12 \%$ de grão de soja cru e integral ou caroço de algodão na alimentação de vacas lactantes, podem substituir parcialmente o fubá de milho e o farelo de soja, sem alterar o desempenho produtivo, digestão e metabolismo. 


\section{OBJETIVOS}

O presente estudo foi conduzido com objetivo de comparar a inclusão de grão de soja cru e integral em relação ao caroço de algodão na substituição parcial do fubá de milho e farelo de soja na alimentação de vacas em lactação. Avaliando os efeitos sobre o consumo e digestibilidade aparente total da matéria seca e nutrientes, fermentação e síntese de proteína microbiana ruminal, produção e composição do leite, e as concentrações de metabólitos sanguíneos. 


\section{REVISÃO DE LITERATURA}

\subsection{SEMENTES OLEAGINOSAS NA ALIMENTAÇÃO DE VACAS LEITEIRAS}

A quantidade de lipídeos normalmente fornecido na dieta basal de vacas lactação é de 3\% MS. Apesar da baixa inclusão, os lipídeos são muito importantes, pois contribuem diretamente com cerca de 50,0 \% da gordura do leite, além de ser a fonte de energia mais concentrada da dieta (NRC 2001). O valor dos lipídeos como combustível fisiológico é de 9,0 $\mathrm{Mcal} / \mathrm{Kg}$, equivalente a cerca de 2,25 a energia de carboidratos e da proteína, mas isso desde que seja absorvida e fique a disposição para ser metabolizada (energia metabolizável). Portanto, varia em função da digestibilidade de cada fonte de lipídeos (LEHNINGER, 2005).

Sendo assim, a suplementação de lipídeos para vacas em lactação é alternativa para elevar o nível energético da dieta, sem aumentar a ingestão de carboidratos não fibrosos ou diminuir a ingestão de fibra, sendo isso possível ao substituirmos os cereais por sementes oleaginosas (PALMQUIST, 1984). A maioria dos ácidos graxos encontrados na natureza tem número de carbonos que comumente varia de 14 a 24 , sendo classificados como saturados (todos os carbonos com ligações simples), ou insaturados (com uma ou mais ligações duplas entre átomos de carbono). Se os ácidos graxos têm única ligação dupla, este pode ser classificado como monoinsaturado, e se este tem de uma ou mais ligações duplas, é classificado como poli-insaturado (LEHNINGER, 2005). Este grau de insaturação é, provavelmente, a característica mais importante que influencia a digestão dos lipídeos em ruminantes, junto a quantidade de lipídeos consumida, características dos lipídeos na dieta basal, e as características das fontes de lipídeos acrescentados (GRUMMER, 1995).

Uma alternativa para suplementação de lipídeos para vacas em lactação seria a inclusão de sementes oleaginosas, que contêm mistura única entre proteína e lipídeos, sendo estes últimos constituídos principalmente por triglicerídeos ricos em ácidos graxos insaturados (NRC, 2001), e ainda, o metabolismo desses lipídeos no rúmen é dependente da taxa de liberação da matriz do alimento. No entanto, esse efeito parece ser minimizado nessas sementes, pelo fato do lipídeo estar contido no germe da semente, necessitando que a parede celular se degrade para que os ácidos graxos insaturados sejam liberados no ambiente ruminal de forma gradual, permitindo que os microrganismos façam a hidrolise (as ligações entre o glicerol e os ácidos graxos sejam quebradas gerando uma molécula de glicerol e três de ácidos 
graxos) e a biohidrogenação, processo onde o ácido graxo se torna saturado, pois a dupla ligação é substituída por dois átomos de hidrogênio (BERCHIELLI; PIRES; OLIVEIRA, 2011).

Quando suplementamos lipídeos através da inclusão de sementes oleaginosas na alimentação de vacas em lactação temos as seguintes vantagens: liberação gradual do óleo no ambiente ruminal; o que diminui a taxa de biohidrogenação ruminal; aumento da ingestão de energia sem redução do $\mathrm{pH}$ ruminal, o que pode ser interessante em situações onde é aconselhável menor inclusão de amido; reduzir o estresse térmico nas vacas de leite em clima quente através do aumento da eficiência do uso de energia em decorrência de menor incremento calórico; substituição de carboidratos rapidamente fermentáveis visando à otimização de consumo de forragem e fermentação ruminal, partição de nutrientes para a secreção do leite; aumento da flexibilidade para o preparo da dieta; utilizados para modificação da composição da gordura do leite e aumento da absorção de nutrientes solúveis. (NRC, 2001; PALMQUIST; MATTOS, 2006).

Embora se apresente como alternativa viável nas dietas de ruminantes como fonte de energia, é preciso considerar que para vacas em lactação o uso de lipídeos pode promover variáveis respostas na produção e composição do leite, sendo dependente da dieta basal fornecida (especialmente o volumoso), estágio de lactação, balanço energético, composição e quantidade da fonte de lipídeo utilizada (ONETTI; GRUMMER, 2004). Um possível efeito negativo da adição de lipídeos é menor CMS, que segundo Allen (2000), ainda não tem seus mecanismos elucidados. Uma possível consequência é a redução da síntese de proteína microbiana ruminal e menor síntese de caseína do leite (DUNKLEY; SMITH; FRANKE, 1977; COPPOCK; WILKS, 1991; VAN SOEST, 1994). Esse tipo de suplementação também pode gerar queda no teor de gordura do leite e da digestibilidade de fibra, que são indicativos de que a fermentação ruminal foi alterada durante o fornecimento de lipídeos na dieta (NRC, 2001).

\subsection{CAROÇO DE ALGODÃO NA ALIMENTAÇÃO DE VACAS LEITEIRAS}

O Caroço de algodão é um coproduto da indústria do algodão muito disponível no Brasil, principalmente na região Centro-Oeste, onde estão as maiores áreas de cultivo. Esta 
semente além de apresentar elevada quantidade de lipídeos e proteína, possui o teor e a efetividade ruminal da fibra semelhante a dos alimentos volumosos o que a torna opção interessante em dietas de vacas de média a alta produção (CLARK; ARMENTANO 1993; ARIELI, 1998). O caroço de algodão apresenta as seguintes porções: casca, línter (aproximadamente 10,0\% do peso do caroço de algodão integral) e plumas. Existem dois tipos comerciais do caroço de algodão: alto línter ou caroço de algodão branco e baixo línter ou caroço de algodão preto (ROGÉRIO et al., 2004; ZHANG et al., 2007).

Segundo o NRC (2001), o caroço de algodão apresenta a seguinte composição química: 90,10\% de matéria seca (MS), 77,22\% de nutrientes digestíveis totais (NDT), $50,30 \%$ de fibra em detergente neutro (FDN), 40,10\% de fibra em detergente ácido (FDA), 23,50\% de proteína bruta (PB), 19,30\% de extrato etéreo (EE), 4,20\% cinzas (MM) e 3,57 $\mathrm{Mcal} / \mathrm{kg}$ de ED. Esta semente oleaginosa possui grande proporção de ácidos graxos poliinsaturados, especialmente o ácido linoleico, que compõe até 55\% dos lipídeos.

Estudos da inclusão desta semente na alimentação de vacas leiteiras remetem a década de 40 do século passado, quando Davis e Harland (1946) substituíram quase um kg de concentrado pela mesma quantidade de caroço de algodão, não encontrando diferença na produção de leite e sólidos. Pouco depois, Stanley et al. ${ }^{1}$ (1969) apud Anderson, Adams e Lamb (1979, p. 6), já mencionavam as vantagens do seu uso na tentativa de manter o consumo de energia de vacas em lactação.

\subsubsection{Consumo e digestibilidade aparente total}

São diversos os efeitos no consumo e na digestibilidade quando se utiliza o caroço de algodão na alimentação de vacas leiteiras, no entanto, estes efeitos são dependentes do teor de inclusão, tipo de volumoso, fase da lactação entre outros fatores relacionados a dieta basal. Anderson, Adams e Lamb (1979) trabalharam com silagens de milho e alfafa como volumoso, tiveram media de ingestão de caroço de algodão de 1,70 kg/dia, enquanto Smith et al. (1979) encontraram media de ingestão de $2,90 \mathrm{~kg} /$ dia de caroço, sem alteração na produção ou saúde dos animais.

\footnotetext{
${ }^{1}$ STANLEY, R. W.; COBB, K.; MORITA, J.; CARPENTER, J. I. The effect of feeding whole cottonseed to lactating dairy cattle on milk and fat production. Hawaii Agr. Exp. Sta. Res., v. 12, 177, 1969.
} 
Quando mantido o mesmo teor de fibra e energia entre as dietas contendo caroço de algodão ou não, esta oleaginosa não apresenta decréscimo no consumo quando seus teores são menores que 20,0 \% na MS da dieta (BELIBASAKIS; TSIRGOGIANNI 1995; SOUSA et al., 2009).

Belibasakis e Tsirgogianni (1995) avaliaram a substituição da torta de algodão por caroço de algodão, na alimentação de 16 vacas leiteiras no terço médio da lactação, e produção média de $25,0 \mathrm{~kg} /$ dia. As dietas foram isonitrogenadas e isoenergéticas, contendo a mesma quantidade de FDN. A base do volumoso foi a silagem de milho, com inclusão de $10,0 \%$ de caroço de algodão na dieta total. Não houve efeito no consumo de matéria seca, proteina bruta e energia metabolizavel.

De forma semelhante, Sousa et al. (2009) utilizaram 12 vacas lactantes, 7/8 Holandês Gir, no terço inicial da lactação, e produção de leite média de $20 \mathrm{~kg} /$ dia. $\mathrm{O}$ volumoso utilizado foi cana de açúcar, com três inclusões de caroço de algodão; 7 e 14,0 \% MS na dieta. Não foi relatado efeito no consumo de MS, PB e NDT entre as dietas que continham a oleaginosa. O consumo de EE foi maior na dieta com maior inclusão da semente, assim como a digestibilidade deste nutriente. Os coeficientes de digestibilidade da MS, PB, CNF, FDN não diferiram entre os tratamentos. Smith et al. (1981) trabalharam com vacas lactantes, e dietas contendo inclusão de caroço de algodão entre 0,90 e $5,10 \mathrm{~kg} /$ dia e não encontraram diferença entre CMS (20 kg/MS/dia) não observando também diferença na digestibilidade da MS e do FDN. Neste estudo, enquanto aumentou a ingestão de EE, ocorreu um efeito linear crescente em sua digestibilidade

Em contrapartida, Lubis et al. (1990) avaliaram CMS de dietas contendo caroço de algodão (15\% na MS da dieta) e variando em 2 níveis de silagem de milho (35\% e 66\%), observaram que a medida em que o teor de fibra da dieta aumentou, o CMS foi reduzido de 23,20 kg/dia para 19,70 kg/dia. De forma semelhante, Coppock et al. (1985) trabalharam com 30 vacas em lactação, tendo silagem de milho como fonte de volumoso, alimentadas com concentrados contendo diferentes inclusão entre 0 e 30,0 \% de caroço de algodão na MS da dieta, encontraram efeito linear decrescente no consumo de matéria. Mesmo assim não foi observada diferença nas digestibilidades da MS e FDN. Em contrapartida, à medida que aumentou a inclusão da semente, também ocorreu aumento da digestibilidade do EE.

Broderick et al. (2013), utilizando 32 vacas da raça Holandesas no terço médio da lactação com produção de leite de 46,0 kg/dia, testaram diferentes formas de processamento do algodão na dieta. Ao substituir o caroço de algodão por torta de algodão, houve aumento 
no CMS (1,4 kg/dia) não sendo observada diferença na digestibilidade da MS, MO e FDN. Havartine et al. (2002) testaram seis dietas contendo 3 diferentes inclusões desta semente oleaginosa (5,0 10,0 e 15,0 \% na MS da dieta), com dois tipos de milho processado em dietas isoenergeticas e isoproteicas, contendo o mesmo níveis de FDN. Os autores relataram que mesmo com o aumento da ingestão do caroço de algodão, os coeficientes de digestibilidade não tiveram diferença.

Coppock et al. (1987) observaram que o fornecimento de caroço de algodão em até $30,0 \%$ da MS não reduz a digestibilidade da dieta, ao contrário do que ocorre proporcionalmente quando se fornece igual quantidade de lipídios na forma livre.

\subsubsection{Fermentação e síntese de proteína microbiana ruminal}

A manutenção de vacas com ambiente ruminal saudável é ponto chave na eficiência do sistema de produção de leite, tanto para a saúde dos animais, aumentando a sua longevidade, quanto para proporcionar condições para maximização da produção. Para isso, a suplementação de caroço de algodão na dieta de vacas lactantes pode ser interessante não só por substituir alimentos contendo carboidratos altamente fermentescíveis como o milho, como também ajudando a manter estável o $\mathrm{pH}$, pela efetividade ruminal da sua fibra (CLARK; ARMENTANO 1993; NRC, 2001). Isto ocorre porque o caroço de algodão com línter se estratifica melhor pelo rúmen, estimula a mastigação e a ruminação contribuindo para o tamponamento, garantindo adequada fermentação (COPPOCK et al., 1987).

Fontes de lipídeos que possuem proteção natural da degradação ruminal, como sementes oleaginosas integrais ou parcialmente quebradas, são inerte sobre a população microbiana, não apresentando toxicidade dos lipídeos sobre os processos de degradação ruminal de nutrientes, especialmente da fibra (ALLEN, 2000; PALMQUIST; MATTOS, 2006). Coppock et al. (1985) avaliaram os efeitos da suplementação do caroço de algodão no $\mathrm{pH}$ ruminal, tendo silagem de milho como fonte volumosa da dieta, não encontram diferença entre as inclusões de $0,15,0$ e $30,0 \%$ de semente nas dietas.

Em quatro experimentos utilizando em média 60 animais por tratamento e no terço inicial da lactação, Sklan et al. (1992), compararam a inclusão de sais de cálcio protegido com caroço de algodão (16,0 \% na MS da dieta).Os autores observaram maior proporção de acido 
acético no rumen para a dieta contendo caroço de algodão. Anderson, Adams e Lamb (1979), no entanto, não observaram diferenças nas porcentagens dos ácidos graxos de cadeia curta (AGCC) e na relação acetato:propionato.

Outro aspecto importante a ser considerado e que é dependente da fermentação ruminal é a síntese de proteína microbiana ruminal, pois impacta significativamente quantidade e qualidade da proteína metabolizável de ruminantes (VALADARES et al., 1999). A sua produção pode ser influenciada pela adição de lipídeos na dieta, quando sua inclusão esta acima do considerado basal (3,0 \% na MS da dieta) para vacas em lactação, as diferentes fontes (saturada e insaturada) podendo interromper a fermentação microbiana e diminuir a digestão da fibra, mudando a proporção de ácidos graxos voláteis, ou interferindo no metabolismo de nitrogênio no rúmen (JENKINS, 1993).

Avaliando a síntese de proteína microbiana com dietas contendo cinco inclusões de caroço de algodão $(0,6,25,12,50,18,75$, e 25,0\% na MS da dieta), Melo et al. (2007) avaliaram cinco vacas raça da Holandesas, em lactação e palma forrageira com silagem de sorgo como fonte de volumoso. Os autores relataram aumento linear nos consumos de MS, MO e NDT, a medida que foi sendo acrescentado caroço de algodão na dieta, sem efeito para a absorção de purinas, síntese de nitrogênio ou PB microbiana, o que sugere uniformidade entre as dietas consumidas pelos animais na eficiência em termos de quantidade e sincronização de disponibilidade de proteína:energia.

Porém, ainda são poucos resultados apresentados na literatura que avaliaram a síntese de proteína microbiana ruminal quando o caroço de algodão foi usado junto com silagem de milho como volumoso.

\subsubsection{Produção e composição do leite}

Os resultados encontrados em relação à produção e composição do leite ao se utilizar caroço de algodão na dieta são muito distintos. Segundo Kajikawa et al. (1991), o efeito do caroço de algodão no desempenho de vacas em lactação depende da quantidade da semente oferecida e das características de fermentação ruminal de cada vaca individualmente.

Sullivan et al. (2004), em estudo com 24 vacas da raça Holandesa alimentadas com quatro teores de CA ( 3,0 6,0 9,0 e 12,0\% na MS da dieta) não observaram diferença na produção média de leite $(32,0 \mathrm{~kg} / \mathrm{dia})$ e teor de gordura de $(3,5 \%)$. De forma semelhante, 
Costa et al. (2011) testaram a inclusão de caroço de algodão (15,0\% na MS da dieta) na alimentação de vacas em lactação, onde o caroço de algodão não influenciou a produção de leite e seu teor de gordura. Outros autores também não observaram efeitos na utilização de caroço de algodão na produção de leite (SMITH et al., 1981; VILLELA et al., 1996; MELO et al., 2006).

Com relação à composição do leite de animais suplementados com caroço de algodão, o efeito mais consistente observado é o aumento no teor de gordura do leite. De acordo com Coppock et al. (1987) em revisão de literatura, inclusões entre 10,0 e 30,0 \% (MS) de caroço de algodão na dieta aumentou a porcentagem de gordura no leite em 8 dentre 13 experimentos, entretanto, somente em quatro houve aumento significativo em relação à dieta controle.

Horner et al. (1988) demonstraram que em dietas contendo caroço de algodão, a concentração de acetato é aumentada de 15,0 a 30,0\%, efeito que pode ser explicado pela fermentação da fibra do algodão, que é de alta digestibilidade e produz ácido acético, disponível para a síntese da gordura do leite. Além disso, a adição da semente oleaginosa permite a redução no conteúdo de amido, com aumento no conteúdo de fibra, sem que haja redução na densidade energética da dieta (COPPOCK et al., 1987). Segundo Belibasakis e Tsirgogianni (1995), este efeito do caroço de algodão, no teor de gordura do leite, está relacionado diretamente ao aumento no consumo de gordura e ao menor incremento calórico dela proveniente. Smith et al. (1981) e Lubis et al. (1990) relataram que dietas com caroço de algodão diminuem a síntese de ácidos graxos de cadeia curta na glândula mamária, porém ocorre transferência dos ácidos graxos de cadeia longa, do caroço de algodão para o leite, o que resulta em aumento líquido da porcentagem e produção de gordura do leite.

Desta maneira, Morais et al. (2013) analisaram a inclusão de caroço de algodão em dietas de vacas leiteiras, com teor de $10,0 \%$ da semente na MS da dieta, em substituição ao farelo de algodão e à polpa cítrica, com silagem de cana-de-açúcar como volumoso, onde mesmo com queda no CMS da dieta contendo caroço de algodão, não prejudica a produção de leite e de leite corrigido para $3,5 \%$ de gordura.

\subsubsection{Parâmetros sanguíneos}

Mudanças no metabolismo ruminal, absorção intestinal, transporte e metabolismo sistêmico, secreção e deposição de lipídeos no organismo, além de respostas zootécnicas, são 
aspectos diretamente ligados ao metabolismo que podem assim influenciar os parâmetros sanguíneos de vacas em lactação recebendo suplementação lipídica (CHRISTENSEN et al., 1994).

Analisando parâmetros sanguíneos, Hawkins et al. (1985) trabalharam com 32 vacas da raça Holandesa em lactação, alimentadas com dietas contendo caroço de algodão (18,5\% na MS da dieta) e dieta controle composta por torta de algodão e soja, silagem de milho como volumoso. Os autores observaram maiores concentrações de lipídios totais e de colesterol no soro de vacas alimentadas com a dieta contendo CA. Este comportamento seguiu a maior ingestão de lipídios por animais tratados com a dieta contendo esta semente oleaginosa, enquanto outros parâmetros sanguíneos avaliados não foram afetados pelas dietas experimentais.

De forma semelhante, Bitman et al. (1996) alimentaram com caroço de algodão (em $10 \%$ na MS da dieta) vacas em épocas distintas do ciclo produtivo, sendo oito vacas secas e 24 vacas em lactação, separadas em dois experimentos. Os animais foram alimentados com alfafa e silagem de milho. Não houve efeito da dieta sobre o colesterol das vacas em lactação (média de $200 \mathrm{mg} / \mathrm{dL}$ ), em contrapartida, entre as vacas secas, as que consumiram caroço de algodão tiveram em seu soro uma maior quantidade de colesterol $(110 \mathrm{mg} / \mathrm{dL})$ do que as que não se alimentaram desta semente oleaginosa (77 mg/dL).

Em estudo supracitado, Belibasakis e Tsirgogianni, (1995) não encontraram diferença na glicose do plasma sanguíneo $(61 \mathrm{mg} / \mathrm{dL})$ e proteína total $(9 \mathrm{mg} / \mathrm{dL})$ quando incluíram caroço de algodão na dieta das vacas em lactação, assim como Martinez, (2008) que também não encontrou diferença nos níveis plasmáticos de glicose $(68 \mathrm{mg} / \mathrm{dL})$ em estudo utilizando vacas em lactação alimentadas com cana de açúcar como fonte de volumoso, e incluindo caroço de algodão ( 17,0 e 34,0\% na MS da dieta). Neste mesmo estudo foi relatado aumento no teor de nitrogênio ureico no plasma dos animais alimentados com maior proporção de caroço de algodão na dieta, provavelmente reflexo da falta de carboidratos não fibrosos e aumento da degradabilidade ruminal da proteína na dieta com maior inclusão desta semente.

\subsection{GRÃO DE SOJA NA ALIMENTAÇÃO DE VACAS LEITEIRAS}

A soja (Glycine max Merill) originária da China, foi introduzida no Brasil na década de 60, e atualmente o país é o segundo maior produtor mundial deste cereal (CONAB, 2013). 
O grão de soja pode ser utilizado na alimentação de ruminantes em sua forma original (crua) e na alimentação de monogástricos e ruminantes na forma processada. A soja integral, devido a sua composição, é excelente fonte de energia e proteína para vacas em lactação (PALMQUIST, 1991), com a vantagem de poder ser produzida diretamente na propriedade (RENNÓ et al., 2009).

O grão de soja apresenta composição de aproximadamente $39,20 \%$ de proteína bruta (PB), 19,20\% de extrato etéreo (EE) e 85,00 a 101,00\% de nutrientes digestíveis totais (NDT) (NRC, 2001; VALADARES FILHO et al., 2002)

Segundo Rennó et al. (2009), os estudos com esta sementes de oleaginosa, se concentram a partir da década de 60 , junto com alimentos que tinham grande disponibilidade nos EUA, como o caroço de algodão, na prospecção de novas fontes de lipídeos para serem utilizadas na alimentação de ruminantes. A utilização do grão de soja cru e integral na alimentação de vacas leiteiras tem sido realizada de forma discreta e cercada de cuidados, em função de potenciais efeitos negativos no desempenho produtivo e saúde dos animais. No entanto (MCDONALD et al., 2002), os ruminantes não apresentam problemas em função da presença de substancias tóxicas, incluindo fatores alergênicos e anticoagulantes que são desativadas ou metabolizadas durante o processo de digestão.

\subsubsection{Consumo e digestibilidade aparente total}

O primeiro fator limitante sobre o desempenho produtivo de vacas leiteiras, esta na ingestão de energia. Este é determinado pelo conteúdo de energia líquida da dieta e pelo consumo de matéria seca (CMS). Ao substituir carboidratos solúveis por sementes oleaginosas, aumenta-se a densidade energética da dieta, sendo assim, é esperado maior consumo de energia, desde que o CMS se mantenha ou não diminua significativamente (WILKS, 1991). Deste modo, muitas pesquisas foram feitas para estimar o consumo e a digestibilidade do grão de soja cru e integral e seus diversos tipos de processamento.

Avaliando o desempenho produtivo de animais alimentados com grão de soja tostado em relação ao farelo de soja e ao grão de soja moído grosseiramente, Faldet e Satter (1991) utilizaram 46 vacas holandesas, multíparas e em início de lactação, com média de produção de leite de $35,0 \mathrm{Kg} /$ dia. $\mathrm{O}$ volumoso utilizado foi à silagem de alfafa, e não foi encontrada 
diferença entre as dietas com farelo de soja ou grão de soja cru moído sobre o consumo. Do mesmo modo Mielke e Shingoethe (1981) testaram dietas com grão de soja cru e processado na alimentação de vacas primíparas em início de lactação. Foi utilizada a silagem de milho como maior parte do volumoso, associada a feno de alfafa. A quantidade de grão de soja consumida foi de 2,19 e 2,14 kg/vaca/dia. Não foi observado efeito entre as dietas utilizadas no consumo de matéria seca e de proteína bruta.

Palmquist e Conrad (1978) utilizaram vacas das raças Holandesa e Jersey, e avaliaram dietas contendo farelo de soja, grão de soja cru moído e uma mistura de gordura hidrogenada em duas proporções, perfazendo cerca de 3,18, 5,93, 5,73 e 10,8\% de extrato etéreo na matéria seca das rações. O resultado obtido com as vacas da raça Holandesa, de média de produção de 31,0 kg/dia, demonstrou que a utilização das fontes de lipídeos não influenciou o consumo de matéria seca, com o menor consumo sendo observado para a dieta contendo grão de soja. Em relação à digestibilidade dos nutrientes, foram observados efeitos da suplementação com fontes de lipídeos, especialmente na digestibilidade do extrato etéreo e da proteína bruta. Nas vacas da raça Jersey, de menor produção, com média de 16,4 kg/dia, não foi observado efeito das dietas experimentais sobre as variáveis avaliadas.

Segundo Scott, Combs e Grummer (1991), é possível fornecer quantidades maiores de grão de soja na alimentação de vacas leiteiras em relação ao comumente recomendado, especialmente se as dietas forem fornecidas por meio de misturas completas (TRM).

Desta maneira, Mora, Leão e Valadares Filho (1996) avaliaram vacas de média produção, após o pico de lactação, alimentadas com silagem de milho como volumoso. $\mathrm{O}$ concentrado contendo 0,0 15,0 30,0 e 45,0\% de grão de soja moído, e a relação volumoso/concentrado de 50/50. Não foi observado efeito das dietas sobre o CMS e de nutrientes, com exceção do consumo de extrato etéreo, que foi maior à medida que aumentava o nível de inclusão de grão de soja nas dietas. O consumo de grão de soja foi de 1,34, 2,73 e 3,65 Kg/dia. Os autores não observaram efeitos das dietas sobre a digestibilidade da MS e da $\mathrm{PB}$, entretanto as dietas experimentais influenciaram positivamente a digestibilidade do extrato etéreo e negativamente a digestibilidade da matéria orgânica e da FDN.

Da mesma forma, Barletta (2010) em estudo utilizando vacas holandesas no terço médio de lactação, avaliando inclusão de 0, 8,0 16,0 24,0\% de grão de soja na MS da dieta. Foi observado efeito linear decrescente no consumo de matéria seca, possivelmente essa redução pode ser justificada em parte pela aceitabilidade da dieta contendo $24,0 \%$ e pelo alto teor de extrato etéreo na mesma, pois o consumo de grão de soja dos animais submetidos à 
inclusão de 24,0\% chegou a atingir 6,0 a 7,0 Kg/vaca/dia para esta dieta experimental. Não houve diferença na digestibilidade aparente total da matéria seca, matéria orgânica, extrato etéreo, carboidratos não fibrosos, fibra em detergente neutro e nos valores de nutrientes digestíveis totais observados para as dietas.

\subsubsection{Fermentação e sintese de proteina microbiana ruminal}

São inúmeros os efeitos das fontes de lipídeos sobre a fermentação ruminal (JENKINS, 1993) isso pode ser atribuída às diferenças entre as estruturas dos lipídios. Dentre esses fatores o grau de insaturação dos ácidos graxos pode ser considerada característica essencial dos lipídeos quando utilizadas como fonte de energia nas dietas de ruminantes. Isso ocorre porque os ácidos graxos insaturados podem inibir a fermentação ruminal em relação a ácidos graxos saturados. Ainda, essa característica específica pode ser justificada pelo fato de que a mistura de ácidos graxos saturados e insaturados pode melhorar a fermentação quando comparada com fontes simples de ácidos graxos (HAVERTINE; ALLEN, 2006).

Das diferentes fontes de ácidos graxos insaturados, o óleo livre, seria o grande causador de distúrbios de fermentação, independente do volumoso utilizado (COPPOCK; WILKS, 1991). Em contra partida, fontes de lipídeos na forma protegida naturalmente da degradação ruminal, como sementes de oleaginosas inteiras ou parcialmente quebradas, possuem efeito inerte sobre a população microbiana, não apresentando toxicidade do lipídeo sobre os processos de degradação ruminal de nutrientes, especialmente da fibra (ALLEN, 2000; PALMQUIST; MATTOS, 2006).

Deste modo, Mohamed (1988) avaliou os efeitos na fermentação ruminal, da suplementação de grão de soja nos seguintes processamentos, farelo de soja, óleo de soja, grão de soja tostado e grão de soja cru e integral, sendo o volumoso composto de $40 \%$ de silagem de milho e $15,0 \%$ de silagem de alfafa. Não houve diferença no pH ruminal e na concentração de amônia. A proporção de acetato também não teve diferença, já a proporção de proprionato aumentou e o butirato diminuiu nas deitas com óleo na forma livre em relação ao grão cru e integral. Barletta (2010), trabalhando com dietas experimentais contendo níveis crescentes de grão de soja cru e integral encontrou efeito linear crescente para a porcentagem 
de ácido propiônico, não houve efeito sobre os valores de $\mathrm{pH}$ ruminal no tempo de coleta avaliado.

A quantificação da síntese de proteína microbiana no rúmen é importante para a nutrição de ruminantes. Segundo Valadares filho (1995), as exigências proteicas dos ruminantes são atendidas mediante a absorção intestinal de aminoácidos provenientes, principalmente, da proteína microbiana sintetizada no rúmen e da proteína dietética nãodegradada no rúmen.

No mesmo estudo, Barletta (2010) obervou que a utilização de teores crescentes de grão de soja integral nas dietas, até o nível de 24,0 \% na MS, não influenciou a síntese de proteína microbiana. Encontrando médias de purinas totais e absorvíveis de (417,90 e 428,20 Mmol/dia) respectivamente e nitrogênio microbiano de 269,90 g/dia, valores estes próximos aos de Vasconcelos (2010), que ao trabalhar com vacas da raça Holandesas, alimentadas com dietas contendo soja em diferentes formas: farelo de soja (dieta controle), soja crua, soja tostada e farelo de soja acrescido de 5,0\% de ureia, utilizando-se silagem de milho como volumoso, não encontrou diferença entre médias de alantoína na urina (416,45 mmol/dia) e no leite $(12,78 \mathrm{mmol} / \mathrm{dia})$, dos derivados de purinas totais $(468,30 \mathrm{mmol} / \mathrm{dia})$, da síntese de proteína microbiana $(287,33 \mathrm{~g} / \mathrm{dia})$ e da eficiência da síntese microbiana $(133,06)$, expressa em g de PB/kg de NDT consumido, não encontrou diferença entre as dietas.

Venturelli (2011), também não observou diferença nas excreções diárias de alantoína na urina e no leite, e ácido úrico na urina e para a produção de urina em L/dia, para as dietas contendo até $27,0 \%$ de grão. Não houve diferença nas concentrações de derivados de purinas, purinas totais e absorvidas, para a produção de nitrogênio microbiano e proteína bruta microbiana, em g/dia, entre as dietas. Também, não foi observada diferença na eficiência da síntese de proteína microbiana entre as rações experimentais. Porém, são escassos na literatura estudos que avaliaram a utilização de fontes de lipídeos e a síntese de proteína microbiana ruminal.

\subsubsection{Produção e composição do leite}

Podemos observar a influencia da inclusão do grão de soja cru e integral na produção e composição do leite em estudos como o de Scott et al. (1991) que avaliaram a utilização desta 
semente processada na alimentação de vacas leiteiras no terço médio de lactação e produção corrigida para 4,0 \% de gordura de 30,5 kg/dia. O grão de soja avaliado foi laminado, moído, moído associado à resíduos de cervejaria seco, tostado e extrusado. As dietas formuladas forneceram em média 4,0 kg/dia de grão de soja por vaca, com exceção para a dieta composta por grão de soja associado ao resíduo de cervejaria seco, que os animais tiveram acesso a menor quantidade de grão de soja. Não foi observada alteração na produção e composição do leite para as dietas que utilizaram grão de soja com o menor nível de processamento, seja moído ou laminado, quando comparado com outras formas de processamento do grão de soja.

De forma semelhante, Faldet e Satter (1991) avaliaram vacas em início de lactação com produção media de $35,0 \mathrm{~kg} / \mathrm{dia}$, comparando o desempenho produtivo de animais alimentados com grão de soja tostado em relação ao farelo de soja e ao grão de soja moído grosseiramente, e o volumoso utilizado foi silagem de alfafa. Foi observado aumento da produção de leite e redução dos teores de gordura e proteína do leite nas vacas alimentadas com grão de soja tostado em relação a dieta com farelo de soja ou grão de soja cru moído. No entanto, não foi encontrada diferença entre as dietas com farelo de soja ou grão de soja cru moído sobre a produção e composição do leite, e consumo.

Além disso, a substituição parcial do farelo de soja e do milho por 10,0 \% de grão de soja extrusada não comprometem a produção de leite $(\mathrm{kg} / \mathrm{dia})$ ou leite corrigido para gordura (BERNARD, 1990; ABUGHAZALEH et al., 2002). Mielke e Shingoethe (1981) avaliaram dietas com farelo de soja, grão de soja cru e grão de soja tostado na alimentação em vacas primíparas em início de lactação e não observaram efeito na produção de leite e teor de gordura. No entanto, a dieta com farelo de soja apresentou maior teor de proteína do leite do que as dietas com grãos de soja moídos ou tostados. Vacas que consumiram grão de soja extrusada geralmente produzem mais leite do que vacas alimentadas com soja crua, no entanto essa diferença desaparece com a correção do leite para 4\% de gordura (VAN DIJK et al., 1983; CHOUINARD et al., 1997; NEVES et al., 2007). Sendo assim, o processamento da soja nesses casos, elevou os custos sem refletir em maior produção.

Barletta (2010), em estudo supracitado, encontrou efeito linear decrescente sobre a produção de leite, onde, os animais que consumiram a dieta com maior inclusão de grão de soja (24,0 \% na MS da dieta) apresentaram menor produção de leite quando comparada as demais dietas utilizadas, não sendo observadas diferenças na produção de leite nos animais submetidos às dietas controle, 8,0 e 16,0 \% . Este resultado pode ser explicado pelo menor consumo de matéria seca, dos animais submetidos à dieta com inclusão $24,0 \%$ de grão de 
soja. Também foi observado efeito das dietas experimentais sobre a produção de proteína no leite, sendo que os animais submetidos às dietas 16,0 e 24,0\% apresentaram valores inferiores aos animais submetidos às dietas não contendo grão de soja e com inclusão de apenas 8,0\% Mora, Leão e Valadares Filho (1996), usando vacas de 26,0 kg/leite/dia, não encontraram diferença na produção e composição do leite com quatro inclusões diferentes de grão de soja na dieta.

Scott, Combs e Grummer (1991) utilizando 10 vacas Holandesas, no terço médio da lactação, separadas em dois quadrados latinos, por alta e baixa produção, 35,0 e 25,0 $\mathrm{kg} / \mathrm{leite} / \mathrm{dia}$, concluíram que se o grão de soja for utilizado como fonte de energia na alimentação de vacas leiteiras, não existe diferença entre as formas de processamento laminação, moagem, tostagem ou extrusão, especialmente para produção e composição do leite.

\subsubsection{Parâmetros sanguíneos}

Variações dos metabólicos sanguíneos em vacas leiteiras permitem estimar o processo de adaptação metabólica a novas situações fisiológicas ou de alimentação. Mohamed (1988) não encontrou diferença na concentração de glicose sanguínea entre dietas contendo grão de soja cru e integral, grão tostado e óleo de soja na forma livre. Já a quantidade de triglicerídeos foi maior nas deitas recebendo suplementação de soja em relação a controle.

Barletta (2010) não encontrou diferença entre as dietas experimentais para as concentrações plasmáticas de glicose, ureia, nitrogênio ureico, proteínas totais, albumina, gama glutamil transferase (GGT) e fosfatase alcalina (FA). Em contra partida, foi observado efeito linear crescente para as concentrações de colesterol total e colesterol HDL. Este resultado semelhante aos encontrados por Freitas Júnior et al. (2010), que avaliaram as concentrações de colesterol total e HDL, glicose, ureia e nitrogênio ureico no soro e as enzimas hepáticas (AST, GGT e FA), de vacas leiteiras alimentadas com 16,0\% de grão de soja integral na matéria seca da dieta.

Petit et al. (2002) avaliaram a suplementação de sais de cálcio de ácidos graxos, sementes de linhaça e soja micronizada como fonte de gordura nas rações de vacas leiteiras no início de lactação com dietas contendo cerca de 8,0\% de EE. Estes autores também 
observaram maior concentração de colesterol para as vacas que consumiram sais de cálcio de ácidos graxos, e baixa concentração para sementes de linhaça. 


\section{MATERIAL E MÉTODOS}

\subsection{LOCAL, INSTALAÇÕES E ANIMAIS}

O presente estudo foi conduzido no Laboratório de Pesquisa em Bovinos de Leite (LPBL) do Departamento de Nutrição e Produção Animal (VNP) da Faculdade de Medicina Veterinária e Zootecnia da Universidade de São Paulo (FMVZ-USP), em Pirassununga, no período de 17 de julho a 17 de setembro de 2012.

A localização geográfica do campus da USP em Pirassununga é $21^{\circ} 59^{`}$ de latitude sul e $47^{\circ} 26^{`}$ de longitude oeste (W.Gr) e altitude média de 635 metros. O clima da região é tropical, com temperatura média durante o experimento de $18,9^{\circ} \mathrm{C}$. As temperaturas máximas e mínimas médias diárias foram de 30,06 e $8,07^{\circ} \mathrm{C}$, respectivamente. A umidade relativa do ar média foi de $68,65 \%$ e a velocidade do vento de $1,53 \mathrm{~km} / \mathrm{h}$.

Foram utilizadas 18 vacas da raça Holandesa, multíparas, com produção média de leite de 32,22 kg/dia, com peso médio de 585,2 $\pm 54,2 \mathrm{~kg}$ e com dias em lactação médio de 133,0 \pm 53,1. Dentre estas 18 vacas havia três canuladas no rúmen que foram utilizadas para mensuração das variáveis ruminais. Os animais foram alojados em estábulo tipo "free-stall", com ventilação forçada, em baias individuais de $17,5 \mathrm{~m}^{2}$ de área e providas de camas de areia, sendo ordenhados mecanicamente duas vezes ao dia, as $6 \mathrm{~h} 00 \mathrm{e}$ as $16 \mathrm{~h} 00$.

\subsection{DELINEAMENTO E DIETAS EXPERIMENTAIS}

Os animais foram distribuídos aleatoriamente em seis quadrados latinos $3 \times 3$, contemporâneos e balanceados. O experimento foi constituído em três períodos, com duração de 21 dias cada um, sendo os 14 primeiros de adaptação às dietas e os demais para avaliar as variáveis mensuradas. Os animais foram alimentados com três dietas durante o período experimental, formuladas para serem isonitrogenadas, com as mesmas proporções de PDR e PNDR de forma a atenderem as exigências nutricionais de vacas em lactação com aproximadamente $580 \mathrm{~kg}$ de peso corporal, com produção diária de leite de 30,0 kg por dia e com 3,5\% de gordura, conforme recomendações do NRC (2001). Foi utilizada dieta na proporção volumoso:concentrado de 50:50. 
As vacas foram alimentadas com as seguintes dietas: 1) Controle (C), composta sem a inclusão de sementes oleaginosas; 2) Grão de soja (GS), com a inclusão de $12 \%$ grão de soja cru integral na MS da dieta; 3) Caroço de algodão (CA), com a inclusão de $12 \%$ caroço de algodão na MS da dieta. As respectivas dietas e água foram fornecidas "ad libitum” durante todo período experimental. O volumoso utilizado durante o experimento foi a silagem de milho.

\subsection{ANÁLISE DE ALIMENTOS}

Diariamente foram feitas pesagens das quantidades dos volumosos e concentrados fornecidos e das sobras de cada animal, para estimativa do consumo. As dietas foram fornecidas duas vezes ao dia, às 7:00 e às 14:00 horas, de acordo com o consumo de matéria seca no dia anterior, de forma a ser mantido um porcentual de sobras das dietas, diariamente, entre 5 e $10 \%$ do fornecido para não haver limitação de consumo.

As duas porções constituintes da dieta, concentrado e volumoso, eram misturadas no cocho e fornecidas na forma de dieta completa. Após o preparo da mistura no cocho, amostras dos alimentos fornecidos foram coletadas e armazenadas a $-20^{\circ} \mathrm{C}$.

As análises bromatológica foram realizadas no Laboratório de Bromatologia e localizado no LPBL. A proporção dos ingredientes no concentrado e dieta total, assim como a respectiva composição bromatológica dos ingredientes, concentrados, dietas experimentais encontram-se nas tabelas 1,2 e 3.

Nos alimentos fornecidos e nas amostras de sobras foram analisados os teores de matéria seca (MS), matéria orgânica (MO), matéria mineral (MM), extrato etéreo (EE), proteína bruta $(\mathrm{PB})$, proteína insolúvel em detergente neutro (NIDN), nitrogênio insolúvel em detergente ácido (NIDA) e lignina de acordo com as metodologias descritas por AOAC (2000). 
Tabela 1 - Composição bromatológica dos ingredientes das dietas experimentais

\begin{tabular}{|c|c|c|c|c|c|}
\hline Composição química & $\mathrm{FS}^{5}$ & Milho $^{6}$ & $\mathrm{GS}^{7}$ & $\mathrm{CA}^{8}$ & $\mathrm{SM}^{9}$ \\
\hline${\text { Matéria Seca }(\mathrm{MS})^{1}}^{1}$ & 89,24 & 89,09 & 91,30 & 91,70 & 42,50 \\
\hline Matéria Orgânica $(\mathrm{MO})^{2}$ & 94,18 & 98,37 & 95,14 & 95,20 & 96,80 \\
\hline Matéria Mineral $(\mathrm{MM})^{2}$ & 5,82 & 1,63 & 4,86 & 4,40 & 3,20 \\
\hline Proteína Bruta $(\mathrm{PB})^{2}$ & 51,20 & 9,97 & 38,10 & 24,12 & 7,05 \\
\hline Extrato Etéreo $(\mathrm{EE})^{2}$ & 2,36 & 2,51 & 20,10 & 18,60 & 2,65 \\
\hline Fibra em Detergente Neutro (FDN) ${ }^{2}$ & 12,22 & 11,20 & 20,08 & 49,02 & 53,50 \\
\hline Carboidratos Não Fibrosos (CNF) ${ }^{2}$ & 28,07 & 74,69 & 17,04 & 4,88 & 37,82 \\
\hline Fibra em Detergente Ácido (FDA $)^{2}$ & 10,69 & 3,40 & 14,66 & 38,70 & 25,66 \\
\hline FDA indigestível (FDAi) $)^{2}$ & 0,80 & 0,74 & 0,90 & 11,01 & 9,10 \\
\hline Lignina $^{2}$ & 2,20 & 1,80 & 2,70 & 6,20 & 5,55 \\
\hline Nutrientes Digestíveis Totais (NDT) ${ }^{4}$ & 79,27 & 82,30 & 98,53 & 83,08 & 66,14 \\
\hline Energia Líquida de Lactação $\left(\mathrm{EL}_{\mathrm{L}}\right)^{4}(\mathrm{Mcal} / \mathrm{Kg})$ & 1,80 & 1,89 & 2,29 & 1,92 & 1,50 \\
\hline Energia Bruta $(\mathrm{Mcal} / \mathrm{Kg})$ & 4,11 & 3,88 & 5,03 & 5,30 & 3,87 \\
\hline
\end{tabular}


Tabela 2 - Ingredientes e composição quimico bromatológica dos concentrados

\begin{tabular}{|c|c|c|c|}
\hline \multirow{2}{*}{ Ingredientes (\%MS) } & \multicolumn{3}{|c|}{ Concentrados } \\
\hline & $\mathrm{C}^{1}$ & $\mathrm{GS}^{2}$ & $\mathrm{CA}^{3}$ \\
\hline Milho moído & 62,20 & 46,72 & 45,74 \\
\hline Farelo de soja & 31,10 & 24,66 & 24,48 \\
\hline Grão de soja & - & 24,06 & - \\
\hline Caroço de algodão & - & - & 24,08 \\
\hline Uréia & 1,14 & - & 1,14 \\
\hline Sulfato de amônia & 0,19 & 0,19 & 0,19 \\
\hline Bicarbonato de sódio & 1,52 & 1,52 & 1,52 \\
\hline Fosfato bicálcico & 0,57 & 0,57 & 0,57 \\
\hline Calcáreo & 1,33 & 1,33 & 1,33 \\
\hline Nutron VitMin ${ }^{4}$ & 0,82 & 0,82 & 0,82 \\
\hline Sal comum & 0,57 & 0,57 & 0,57 \\
\hline
\end{tabular}

Composição química

\begin{tabular}{|c|c|c|c|}
\hline Matéria seca $(\% \mathrm{MN})^{5}$ & 89,68 & 90,10 & 90,31 \\
\hline Matéria orgânica $(\% \mathrm{MS})^{6}$ & 90,91 & 91,69 & 90,60 \\
\hline Proteína bruta $(\% \mathrm{MS})^{6}$ & 26,04 & 26,39 & 26,26 \\
\hline $\mathrm{NIDN}(\% \mathrm{NT})^{7}$ & 8,93 & 11,03 & 9,04 \\
\hline NIDA $(\% \mathrm{NT})^{7}$ & 5,68 & 5,28 & 4,97 \\
\hline Extrato etéreo $(\% \mathrm{MS})^{6}$ & 2,31 & 6,64 & 6,25 \\
\hline $\mathrm{FDN}(\% \mathrm{MS})^{6}$ & 10,83 & 13,04 & 20,02 \\
\hline FDA $(\% \mathrm{MS})^{6}$ & 5,54 & 7,76 & 13,59 \\
\hline FDAi $(\% \mathrm{MS})^{6}$ & 0,71 & 0,76 & 3,22 \\
\hline Lignina $(\% \mathrm{MS})^{6}$ & 1,82 & 2,03 & 2,86 \\
\hline Cinzas $(\% \mathrm{MS})^{6}$ & 9,09 & 8,31 & 9,40 \\
\hline $\mathrm{CNF}(\% \mathrm{MS})^{6}$ & 51,71 & 48,53 & 38,08 \\
\hline $\mathrm{NDT}(\% \mathrm{MS})^{8}$ & 74,00 & 78,80 & 75,37 \\
\hline $\mathrm{EL}_{\mathrm{L}}(\mathrm{Mcal} / \mathrm{kg} \mathrm{MS})$ & 1,69 & 1,83 & 1,71 \\
\hline EB (Mcal/kg MS) & 3,71 & 4,02 & 4,04 \\
\hline
\end{tabular}

${ }^{\mathrm{T}}$ Controle; ${ }^{2}$ Grão de soja integral; ${ }^{3}$ Caroço de algodão;

${ }^{4}$ Composição por $\mathrm{kg}$ do produto: $125 \mathrm{mg}$ de $\mathrm{Co}, 5625 \mathrm{mg} \mathrm{de} \mathrm{Cu}$, 9mg de S, $312 \mathrm{mg}$ de I, $5000 \mathrm{mg}$ de Fe, $18125 \mathrm{mg}$ de Mn, $144 \mathrm{mg}$ de Se, $23750 \mathrm{mg}$ de Zn, 2000 UI de Vit A, 500 UI de Vit D e 12500 UI de Vit E. 5Valor expresso em porcentagem da matéria natural; 6 Valores expressos em porcentagem da matéria seca; 7 Valores expressos em porcentagem do nitrogênio total; 8Valores estimados pelas equações do NRC (2001) . 
Tabela 3 - Ingredientes e composição químico bromatológica das dietas

\begin{tabular}{|c|c|c|c|}
\hline \multirow{2}{*}{ Ingredientes (\%MS) } & \multicolumn{3}{|c|}{ Dietas } \\
\hline & $\mathrm{C}^{1}$ & $\mathrm{GS}^{2}$ & $\mathrm{CA}^{3}$ \\
\hline Silagem de milho & 50,00 & 50,00 & 50,00 \\
\hline Milho moído & 31,09 & 23,35 & 22,87 \\
\hline Farelo de soja & 16,05 & 12,33 & 12,23 \\
\hline Grão de soja & - & 12,03 & - \\
\hline Caroço de algodão & - & - & 12,03 \\
\hline Uréia & 0,57 & - & 0,57 \\
\hline Sulfato de amônia & 0,09 & 0,09 & 0,09 \\
\hline Bicarbonato de sódio & 0,76 & 0,76 & 0,76 \\
\hline Fosfato bicálcico & 0,28 & 0,28 & 0,28 \\
\hline Calcáreo & 0,66 & 0,66 & 0,66 \\
\hline Nutron VitMin ${ }^{4}$ & 0,19 & 0,19 & 0,19 \\
\hline Sal comum & 0,28 & 0,28 & 0,28 \\
\hline \multicolumn{4}{|l|}{ Composição química } \\
\hline Matéria orgânica $(\% \mathrm{MS})^{5}$ & 93,85 & 94,24 & 93,85 \\
\hline Proteína bruta $(\% \mathrm{MS})^{5}$ & 16,54 & 16,71 & 16,54 \\
\hline $\mathrm{NIDN}(\% \mathrm{NT})^{6}$ & 9,70 & 10,79 & 9,70 \\
\hline NIDA $(\% \mathrm{NT})^{6}$ & 4,96 & 4,76 & 4,61 \\
\hline Extrato etéreo $(\% \mathrm{MS})^{5}$ & 2,47 & 4,64 & 4,45 \\
\hline $\mathrm{FDN}(\% \mathrm{MS})^{5}$ & 32,91 & 34,02 & 37,50 \\
\hline FDA $(\% \mathrm{MS})^{5}$ & 15,58 & 16,70 & 19,62 \\
\hline FDAi $(\% \mathrm{MS})^{5}$ & 4,90 & 4,92 & 6,10 \\
\hline Lignina $(\% \mathrm{MS})^{5}$ & 3,65 & 3,76 & 4,10 \\
\hline Cinzas( $\% \mathrm{MS})^{5}$ & 6,14 & 5,75 & 6,30 \\
\hline $\mathrm{CNF}(\% \mathrm{MS})^{5}$ & 41,91 & 38,80 & 35,94 \\
\hline $\mathrm{NDT}^{7}$ & 69,82 & 72,20 & 70,70 \\
\hline $\mathrm{EL}_{\mathrm{L}}(\mathrm{Mcal} / \mathrm{kg} \mathrm{MS})^{7}$ & 1,59 & 1,65 & 1,61 \\
\hline EB (Mcal/kg MS) & 3,79 & 3,95 & 3,96 \\
\hline
\end{tabular}

1Controle; 2Grão de soja integral; 3Caroço de algodão; 4Composição por $\mathrm{kg}$ do produto: $125 \mathrm{mg}$ de $\mathrm{Co}, 5625 \mathrm{mg} \mathrm{de} \mathrm{Cu}, 9 \mathrm{mg}$ de S, $312 \mathrm{mg}$ de I, $5000 \mathrm{mg}$ de Fe, $18125 \mathrm{mg}$ de Mn, $144 \mathrm{mg}$ de Se, $23750 \mathrm{mg}$ de Zn, 2000 UI de Vit A, 500 UI de Vit D e 12500 UI de Vit E. 5 Valores expressos em porcentagem da matéria seca; 6 Valores expressos em porcentagem do nitrogênio total; 7 Valores estimados pelas equações do NRC (2001) . 
O teor de proteína bruta $(\mathrm{PB})$ foi obtido pelo produto da multiplicação do teor de nitrogênio total por 6,25. Os teores de carboidratos não-fibrosos (CNF) foram calculados segundo Hall (1998) onde: $\mathrm{CNF}=100-[(\% \mathrm{~PB}-\% \mathrm{~PB}$ Ureia $+\%$ Ureia $)+\% \mathrm{EE}+\% \mathrm{MM}+$ $\%$ FDN].

Os nutrientes digestíveis totais foram calculados conforme equações do NRC (2001), em que: $\mathrm{NDT}=\mathrm{CNFD}+\mathrm{PBD}+(\mathrm{AGD} * 2,25)+\mathrm{FDND}-7$, onde PBD, CNFD, FDND e AGD representam o total destes nutrientes digestíveis. Os teores de fibra detergente neutro (FDN), fibra detergente neutro livre de cinza e proteína (FDNcp), e fibra detergente ácido (FDA) foram obtidos conforme método descrito por Van Soest e Mason (1991), utilizando-se $\alpha$-amilase e sem adição de sulfito de sódio na determinação do FDN, em Sistema Ankon®.

\subsection{DIGESTIBILIDADE APARENTE TOTAL}

Para estimativa da digestibilidade aparente total dos nutrientes e da matéria seca, as amostras de fezes foram coletadas duas vezes ao dia, no $16^{\circ}, 17^{\circ}$ e $18^{\circ}$ dias de cada período experimental. Um "pool" de amostras de cada animal foram acondicionados em sacos plásticos e armazenados em freezer à $-20^{\circ} \mathrm{C}$. As amostras de alimentos, sobras e fezes foram pré-secas em estufa com ventilação forçada $\left(60^{\circ} \mathrm{C} / 72\right.$ horas $)$ e processadas em moinho de facas com peneiras de porosidade $2 \mathrm{~mm}$.

A excreção total de fezes de cada animal foi estimada pela concentração do indicador interno de fibra em detergente ácido indigestível (FDAi). Na avaliação das frações químicas dos componentes indigestíveis, utilizou-se 4 repetições de cada amostra pré-seca, as quais foram acondicionadas em sacos de tecido não-tecido (TNT-100g/ $\mathrm{m}^{2}$ ), com dimensões de 4 x 5 $\mathrm{cm}$, segundo a relação de $20 \mathrm{mg}$ de matéria seca por centímetro quadrado de superfície (NOCEK, 1988).

Segundo metodologia adaptada por Casali et al. (2008) as amostras foram incubadas por 288 horas no rúmen de duas vacas em lactação canuladas da raça Holandesa, previamente adaptados com concentrado a base de farelo de soja e milho moído e volumoso a base de silagem de milho.

Após a retirada do rúmen os sacos foram lavados com água corrente até o total clareamento desta, e imediatamente conduzidos à estufa de ventilação forçada $\left(60^{\circ} \mathrm{C}\right.$ por 72 horas). 
Posteriormente, os sacos foram submetidos ao tratamento com detergente ácido (MERTENS, 2002) por uma hora, em equipamento analisador de fibra Ankon®. Após este período foram lavados com água quente e acetona e secos em estufa não ventilada $\left(105^{\circ} \mathrm{C}\right.$ por 45 minutos), sendo retirados, acondicionados em dessecador (20 sacos/dessecador), e pesados obtendo-se ao final deste tratamento, a concentração de FDAi. Não foi feito qualquer ensaio para estimar a taxa de recuperação do indicador e este foi considerado como $100 \%$.

\subsection{FERMENTAÇÃO RUMINAL}

Foram utilizadas para avaliação da fermentação ruminal três animais do quadrado constituído de vacas canuladas no rúmen. As amostras de líquido ruminal foram coletadas no $21^{\circ}$ dia do período experimental, sendo uma coleta realizada antes da alimentação (0h), e seis coletas com intervalos de 2 horas após a primeira alimentação (2, 4, 6, 8, 10 e 12h). As amostras de líquido ruminal foram obtidas pela combinação de 5 alíquotas coletadas em 5 pontos diferentes no rúmen. O líquido ruminal foi utilizado para determinação do $\mathrm{pH}$, concentração de nitrogênio amoniacal e ácidos graxos de cadeia curta.

No laboratório as amostras foram centrifugadas a $2.000 \mathrm{x}$ g por 15 minutos, $2 \mathrm{~mL}$ do sobrenadante foi colocado em tubo de ensaio e adicionando-se $0,4 \mathrm{~mL}$ de ácido fórmico P.A., arrolhado e identificado e armazenado em congelador a $-20^{\circ} \mathrm{C}$ para determinação de ácidos graxos de cadeia curta. Da mesma amostra $2 \mathrm{~mL}$ do sobrenadante foi pipetado e armazenado em tubos de ensaio contendo $1 \mathrm{~mL}$ de ácido sulfúrico a $1 \mathrm{~N}$, para posterior determinação da concentração de N-NH3.

A metodologia utilizada para análise de AGCC foi a preconizada por Erwin et al. (1961), sendo utilizado cromatógrafo a gás (Modelo 9001 Gás Chromatograph, Marca Finnigan) equipado com coluna de vidro Capilar - Stabilwax de 30m de comprimento e

$0.53 \mathrm{~mm}$ de diâmetro interno. Os gases utilizados foram o Hélio como gás de arraste na vazão de 8,01 mL/minuto, ar sintético como gás comburente na vazão de $40 \mathrm{kPa}$, e hidrogênio como gás combustível na vazão de $60 \mathrm{kPa}$. A temperatura de operação utilizadas do injetor e do detector de ionização de chamas foram de $250^{\circ} \mathrm{C}$ e da coluna de separação de $145^{\circ} \mathrm{C}$. 
.Soluções padrão a 0,1 Normal de ácido acético, propiônico e butírico foram preparadas e padronizadas com hidróxido de potássio $(\mathrm{KOH})$ 0,1 Normal, a fim de produzir solução padrão de ácidos graxos voláteis de concentração conhecida. As determinações foram realizadas injetando-se $1 \mu \mathrm{L}$ de amostra em cromatógrafo integrado a computador, que processava os cálculos de quantificação, utilizando-se do software BORWIN versão 1.21 para cromatografia.

O N-NH3 foi determinado pelo método de ácido salicílico. Foram adicionados aos tubos contendo amostras de líquido ruminal e ácido sulfúrico a $1 \mathrm{~N}, 1 \mathrm{~mL}$ de tungstato de sódio a $10 \%$, e posteriormente as amostras foram centrifugadas a $1.200 \times \mathrm{g}$ durante 15 minutos. Em seguida foram pipetados $25 \mu \mathrm{L}$ do sobrenadante a um tubo limpo e neste adicionados $5 \mathrm{~mL}$ do reagente fenol e $5 \mathrm{~mL}$ de hipoclorito.

Os tubos foram agitados para homogeneização das amostras e colocados em banhomaria a $37^{\circ} \mathrm{C}$ durante 15 minutos adquirindo coloração azul. Após resfriamento as amostras foram analisadas em espectofotômetro quanto a sua absorbância e os resultados obtidos foram utilizados em equação de regressão para calcular a concentração em mg/dL, onde: Concentração de N-NH3 (mg/dL) = Absorbância $-(a) / b$;

\subsection{SÍNTESE DE PROTEÍNA MICROBIANA}

As amostras utilizadas para análise de alantoína no leite foram coletadas de dois dias seguidos, sendo provenientes das duas ordenhas diárias. Uma alíquota de $10 \mathrm{~mL}$ de leite foi diluída com $5 \mathrm{~mL}$ de ácido tricloroacético a $25 \%$, sendo filtrada em papel-filtro e congelada para posterior determinação dos níveis de ureia e alantoína no leite desproteinizado. Alíquotas de $50 \mathrm{~mL}$ de urina (amostra spot) foram obtidas de todas as vacas no $16^{\circ}$ dia do período experimental, aproximadamente 4 horas após a alimentação, durante micção estimulada por massagem na vulva. A urina foi filtrada e alíquotas de $10 \mathrm{~mL}$ foram diluídas imediatamente em $40 \mathrm{~mL}$ de ácido sulfúrico a 0,036 N para evitar destruição bacteriana dos derivados de purinas e precipitação do ácido úrico. Uma amostra de urina pura foi armazenada para determinação dos compostos nitrogenados totais, de ureia e creatinina.

As concentrações de creatinina foram determinadas por meio de kits comerciais (Bioclin®), utilizando reação enzimática calorimétrica cinética em aparelho SBA-200 
CELM®. O volume urinário total diário foi estimado dividindo-se as excreções urinárias diárias de creatinina pelos valores observados de concentração de creatinina na urina das amostras spot, segundo Oliveira et al. (2001).

A excreção urinária diária de creatinina foi estimada a partir da excreção média diária, estabelecida de 24,05 mg/kg de peso vivo para vacas leiteiras (CHIZZOTTI, 2004). Dessa forma, com a excreção média diária de creatinina e a concentração de creatinina $(\mathrm{mg} / \mathrm{dL})$ na amostra spot de urina, foi estimado o volume total diário de urina, em litros por vaca/dia. Os níveis de alantoína na urina e os de ácido úrico na urina e alantoína do leite foram determinados pelo método colorimétrico, conforme metodologia de Fujihara et al. (1987), descrita por Chen e Gomes (1992).

A excreção total de derivados de purinas foi calculada pela soma das quantidades de alantoína e ácido úrico excretadas na urina e da quantidade de alantoína excretada no leite, expressas em mmol/dia. As purinas microbianas absorvidas (Pabs, mmol/dia) foram calculadas a partir da excreção de derivados de purinas (DP, mmol/dia), por meio da equação Pabs $=\left(\mathrm{DP}-0,236 * \mathrm{PV}^{\wedge}{ }^{0,75}\right) / 0,84$, em que 0,84 é a recuperação de purinas absorvidas como derivados de purina e $0,236^{*} \mathrm{PV}^{\wedge 0,75}$, a excreção endógena de derivados de purina (ORELLANA BOERO et al., 2001).

Foram avaliadas também as purinas absorvidas, considerando-se a excreção endógena de $0,512 * \mathrm{PV}^{\wedge} 0,75$ e a recuperação de 0,70 encontradas por González-Ronquillo et al. (2003). A síntese ruminal de compostos nitrogenados (Nmic, gN/dia) foi calculada com base nas purinas absorvidas (Pabs, mmol/dia), utilizando-se a equação (CHEN; GOMES, 1992): Nmic $=(70 * \mathrm{Pabs}) /(0,83 * 0,134 * 1.000)$, em que 70 é o conteúdo de $\mathrm{N}$ nas purinas $(\mathrm{mgN} / \mathrm{mol})$; 0,134, a relação $\mathrm{N}$ purina: $\mathrm{N}$ total nas bactérias (VALADARES et al., 1999); e 0,83, a digestibilidade intestinal das purinas microbianas.

\subsection{BALANÇO DE ENERGIA}

Para obtenção do consumo de energia bruta e realização do cálculo da eficiência do uso de energia consumida, as amostras de silagem, ingredientes e concentrados foram analisadas quanto ao seu teor de energia bruta em bomba calorimétrica, de acordo com Havartine e Allen (2006). O consumo de energia digestível (CED) foi obtido por meio do 
produto dos coeficientes de digestibilidade da matéria seca observados e dos consumos de energia bruta, de acordo com a energia nos ingredientes da dieta (HAVARTINE; ALLEN, 2006).

O consumo de energia líquida (CELI) foi calculado a partir dos teores de energia líquida nos alimentos e nas sobras, obtidos a partir da equação do NRC (2001), apresentada na seção consumo de matéria seca e nutrientes (1.3). A energia líquida de lactação foi estimada a partir da seguinte equação do NRC (2001): $\mathrm{EL}_{\mathrm{L}}(\mathrm{Mcal} / \mathrm{dia})=$ produção de leite $(\mathrm{kg}) \times(0,0929$ $\times \mathrm{G} \%+0,0547 \times \mathrm{P} \%+0,0395 \times \mathrm{L} \%$ ), onde: $\mathrm{G} \%$ é teor de gordura no leite; P\% é o teor de proteína do leite e L\% é o teor de lactose. A energia líquida de mantença foi estimada, de acordo com o NRC (2001), como $\mathrm{EL}_{\mathrm{M}}=0,08 * \mathrm{PV}^{0,75}$ e o balanço de energia (BE) obtido pela diferença entre o CELI e $E L_{L}+E L_{M}$.. A eficiência de utilização de energia foi calculada através da relação da $\mathrm{EL}_{\mathrm{L}}$ e o CED.

\subsection{BALANÇO DE NITROGÊNIO}

Para o cálculo de balanço de nitrogênio foi realizada a determinação da concentração de creatinina na urina de acordo com metodologia descrita por Valadares et al. (1999) e Rennó (2003). As amostras spot de $50 \mathrm{~mL}$ de urina foram obtidas de todas as vacas no $16^{\circ}$ dia de cada período experimental, quatro horas após a alimentação matinal, durante micção estimulada por massagem na vulva. As alíquotas de $50 \mathrm{~mL}$ de urina (amostra spot) foram filtradas e alíquotas de $10 \mathrm{~mL}$ foram diluídas imediatamente em $40 \mathrm{~mL}$ de ácido sulfúrico a $0,036 \mathrm{~N}$ e armazenadas a $-20^{\circ} \mathrm{C}$. Uma amostra de urina pura foi armazenada para determinação dos compostos nitrogenados totais, de ureia e creatinina.

As concentrações de creatinina foram determinadas por meio de kits comerciais (Bioclin®), utilizando reação enzimática colorimétrica cinética em aparelho SBA-200 CELM®. Para a realização dessa análise, $100 \mu \mathrm{L}$ de urina foram diluídos em $4.900 \mu \mathrm{L}$ de água deionizada. Os resultados obtidos foram calculados pela seguinte fórmula: Creatinina $(\mathrm{mg} / \mathrm{dL})=$ creatinina $(\mathrm{mg} / \mathrm{dL}) * 0,020 * 50($ BIGGS; COPPER, 1961).

O volume urinário total diário foi estimado dividindo-se as excreções urinárias diárias de creatinina pelos valores observados de concentração de creatinina na urina das amostras spot, segundo Oliveira et al. (2001). A excreção urinária diária de creatinina foi estimada a 
partir da proposição de 24,05 mg/kg de peso vivo (PV) (CHIZZOTTI, 2004). Dessa forma, com a excreção média diária de creatinina e a concentração de creatinina (mg/dL) na amostra spot de urina, foi estimado o volume total diário de urina, em litros por vaca/dia, para o cálculo do balanço de nitrogênio.

O consumo de nitrogênio foi determinado dividindo-se o consumo de proteína bruta pelo fator de conversão do nitrogênio total para proteína bruta de 6,25, obtendo-se a quantidade de nitrogênio consumido. $\mathrm{O}$ mesmo cálculo foi realizado com os valores de proteína bruta das fezes obtendo-se a excreção total de nitrogênio.

O nitrogênio total das amostras de urina e leite foi determinado de acordo com as metodologias descritas por AOAC (2000).

O balanço de nitrogênio foi obtido subtraindo do total de nitrogênio em gramas consumido os valores de nitrogênio na urina, fezes e leite, obtendo-se os valores de nitrogênio retido em gramas e em porcentagem do nitrogênio total consumido.

\subsection{PRODUÇÃO E COMPOSIÇÃO DO LEITE}

As vacas foram ordenhadas mecanicamente duas vezes ao dia, as $6 \mathrm{~h} 30$ e às $15 \mathrm{~h} 30$ horas, sendo a produção de leite registrada diariamente durante todo o período experimental. A produção de leite foi corrigida para 3,5\% de gordura (PLC) segundo fórmula de Sklan et al. (1992), onde PLC $=(0,432+0,1625 *$ teor de gordura do leite $) * \mathrm{~kg}$ de leite.

As amostras utilizadas para análise da composição do leite foram obtidas no $16^{\circ}$ e $17^{\circ}$ dia de cada período experimental, sendo cada amostra proveniente das duas ordenhas diárias. Foram determinados os teores de gordura, proteína e lactose. Para a determinação da gordura no leite foram utilizadas amostras a fresco, segundo a metodologia descrita por Gerber (COELHO; ROCHA, 1977) no Laboratório de Tecnologia de Produtos de Origem Animal do VNP-FMVZ-USP. Também foram realizadas as análises de nitrogênio total (NT) e lactose utilizando o equipamento LACTOSCAN no Laboratório de bromatologia do LPBL. Para determinação da ureia e nitrogênio ureico no leite, as amostras de leite foram desproteinizadas da mesma forma que as amostras utilizadas na análise da alantoína. As análises da concentração de ureia no leite desproteinizado foram realizadas por meio de kits comerciais (Bioclin ${ }^{\circledR}$ e CELM®). 


\subsection{METABÓLITOS SANGUINEOS}

As coletas de sangue foram realizadas no $15^{\circ}$ dia de cada período experimental por punção da veia e/ou artéria coccígea, anteriormente ao fornecimento das rações no período da manhã. As amostras foram coletadas em tubos com vácuo (vacutainer) de $10 \mathrm{~mL}$ para dosagem de glicose, colesterol total, colesterol-HDL, proteínas totais, albumina, ureia e nitrogênio ureico, enzimas hepáticas aspartato aminotransferase (AST) e gama glutamil transferase (gama GT), no soro.

Imediatamente após coleta as amostras foram coletadas, refrigeradas e centrifugadas a 2000 x g durante 15 minutos, para a separação do soro. O soro obtido foi transferido para tubetes plásticos, identificados e armazenados a $-20^{\circ} \mathrm{C}$, até o procedimento das análises laboratoriais.

As análises das concentrações dos variáveis sanguíneas foram realizadas no Laboratório de Bioquímica e Fisiologia Animal VNP-FMVZ-USP, por meio de kits comerciais (Bioclin ${ }^{\circledR}$ e CELM $\left.®\right)$ que utilizam método enzimático colorimétrico de ponto final, sendo a leitura realizada em analisador automático de bioquímica sanguínea (SBA-200 CELM®). 


\section{ANÁLISES ESTATÍSTICAS}

Os dados obtidos foram submetidos ao SAS (Version 9.3, SAS Institute, Cary, NC 2010), verificando a normalidade dos resíduos e a homogeneidade das variâncias pelo PROC UNIVARIATE. Os dados foram analisados, pelo PROC MIXED de acordo com a seguinte modelo:

$$
Y_{i j k y}=\mu+Q_{i}+P_{y}+T_{k}+A_{j}\left(Q_{i}\right)+e_{i j y k}
$$

Onde: $\mathrm{Y}_{\mathrm{ijyk}}=$ variável dependente, $\mu=$ media geral, $\mathrm{Q}_{\mathrm{i}}=$ efeito de quadrado $(\mathrm{i}=1 \mathrm{de}$ 64), $\mathrm{P}_{\mathrm{y}}=$ efeito do período $(\mathrm{y}=1$ de 3$), \mathrm{T}_{\mathrm{k}}=$ efeito do tratamento $(\mathrm{k}=1$ de 3$)$, e $\mathrm{e}_{\mathrm{ijk}}=$ erro. Efeito aleatório $\mathrm{A}_{\mathrm{j}}\left(\mathrm{Q}_{\mathrm{i}}\right)$ = efeito do animal dentro do quadrado. Os graus de liberdade calculados foram realizados de acordo com o método satterthwaite $(\mathrm{ddfm}=$ satterth $)$.

Os dados obtidos foram submetidos à análise de variância e análise de contrastes ortogonais pelo comando CONTRAST do PROC MIXED do SAS, (Version 9.3, SAS Institute, Cary, NC 2010), adotando-se teor de significância de 5\%. Os contrastes ortogonais, previamente estabelecidos foram os seguintes: C1: Controle $v s$ oleaginosas: $\mathrm{C}-(\mathrm{GS}+\mathrm{CA})$; C2: Grão de soja vs caroço de algodão: GS - CA. 


\section{RESULTADOS E DISCUSSÕES}

\subsection{CONSUMO E DIGESTIBILIDADE.}

Foi observado maior consumo $(\mathrm{P}<0,05)$ de $\mathrm{MS}, \mathrm{MO}, \mathrm{CNF}, \mathrm{EE}(\mathrm{kg} / \mathrm{dia})$ para os animais que foram alimentados com a dieta controle (CMS superior em $980 \mathrm{~g} / \mathrm{dia}$ ou 3,96\% de MS) em comparação com as dietas contendo sementes (GS e CA). O maior consumo de matéria seca deste grupo de animais pode ser explicado pela menor densidade energética contida na dieta sem inclusão de sementes oleaginosas (Tabela 3). Estes resultados são semelhantes aos de Mohamed (1988), que analisou a inclusão de caroço de algodão (12,50\% MS) e grão de soja (20,0\% MS) na dieta de vacas da raça Holandesa em lactação e observou menor CMS (2,20 e 1,60 kg/dia respectivamente) nos animais alimentados com dietas contendo sementes oleaginosas em relação aos que consumiram dieta controle.

Entre as sementes, houve maior CMS $(\mathrm{P}<0,05)$ dos animais alimentados com grão de soja (4,90 \% MS) em relação ao caroço de algodão. Uma possível explicação para à redução do CMS com a inclusão do caroço de algodão, seria um aumento no teor de FDN desta dieta. Os teores de FDN da dietas CA foi 4,59 \% maior que da dieta C e 3,48\% maior que da GS (Tabela 3). Além disso, foi observado tendência de consumo de FDN em percentual do peso vivo $(1,47 \%$ do PV) nas vacas alimentadas com caroço de algodão em relação ao grão de soja $(\mathrm{P}<0,057)$.

Foi observado efeito no consumo de $\mathrm{CNF}(\mathrm{P}<0,05)$ onde as vacas que consumiram dieta controle tiveram em média, ingestão de $1,25 \mathrm{~kg}$ de CNF a mais que os animais que se alimentaram com sementes oleaginosas. Este efeito pode ser explicado tanto pelo maior CMS dos animais submetidos à dieta controle, $(\mathrm{P}<0,05)$ quanto pela maior teor de CNF contida nesta dieta (Tabela 3). À medida que o grão de soja ou caroço de algodão foi incluído, foi reduzida a proporção de fubá de milho, um ingrediente rico em $\mathrm{CNF}$, consequentemente as dietas com inclusão de sementes foram compostas por menores teores de CNF. Resultado semelhante ao observado por Barletta (2010) em estudo com teores crescentes de grão de soja (8,0 16,0 e 24,0\% MS) na dieta de vacas raça Holandesa no terço médio da lactação, e observou efeito linear decrescente no consumo de CNF à medida que a semente oleaginosa foi incluída na dieta. 
Entre as sementes oleaginosas, os animais alimentados com grão de soja consumiram $16,30 \%$ de CNF $(\mathrm{P}<0,05)$ a mais. Este efeito é explicado pelo menor CMS dos animais alimentados com inclusão de caroço de algodão na dieta. Além desta dieta ser constituída de menor teor de CNF dentre as dietas contendo sementes oleaginosas .

Tabela 4 - Consumo e digestibilidade aparente total da matéria seca e dos nutrientes de vacas lactantes alimentadas com inclusão de sementes oleaginosas ou não

\begin{tabular}{|c|c|c|c|c|c|c|}
\hline \multirow{2}{*}{ Parâmetros } & \multicolumn{3}{|c|}{$\operatorname{Dietas}^{1}$} & \multirow{2}{*}{$\mathrm{EPM}^{2}$} & \multicolumn{2}{|c|}{$P^{2}$} \\
\hline & $\mathrm{C}$ & GS & $\mathrm{CA}$ & & $\mathrm{C} 1$ & $\mathrm{C} 2$ \\
\hline \multicolumn{7}{|c|}{ Consumo kg/dia } \\
\hline Matéria seca & 25,04 & 24,67 & 23,46 & 0,43 & 0,043 & 0,031 \\
\hline Matéria orgânica & 23,52 & 23,25 & 21,94 & 0,41 & 0,047 & 0,011 \\
\hline Proteína bruta & 4,07 & 4,09 & 3,78 & 0,07 & 0,106 & 0,002 \\
\hline Extrato etéreo & 0,71 & 1,14 & 0,98 & 0,03 & $<0,001$ & 0,002 \\
\hline Fibra detergente neutro & 8,35 & 8,45 & 8,77 & 0,16 & 0,166 & 0,132 \\
\hline Carboidratos não fibrosos & 9,35 & 8,82 & 7,38 & 0,18 & $<0,001$ & $<0,001$ \\
\hline $\begin{array}{l}\text { Nutrientes digestiveis } \\
\text { totais }\end{array}$ & 17,76 & 17,91 & 16,70 & 0,30 & 0,234 & 0,005 \\
\hline \multicolumn{7}{|c|}{ Consumo Mcal/dia } \\
\hline $\mathrm{EL}_{\mathrm{L}}$ & 40,86 & 41,70 & 38,09 & 0,61 & 0,205 & 0,002 \\
\hline \multicolumn{7}{|c|}{ Coeficiente de Digestibilidade \% } \\
\hline Matéria seca & 66,71 & 67,42 & 67,54 & 0,52 & 0,416 & 0,912 \\
\hline Matéria orgânica & 68,36 & 68,77 & 68,33 & 0,51 & 0,840 & 0,682 \\
\hline Proteína bruta & 71,16 & 69,09 & 70,73 & 0,59 & 0,286 & 0,119 \\
\hline Extrato etéreo & 83,93 & 86,51 & 87,74 & 0,52 & 0,001 & 0,250 \\
\hline Fibra detergente neutro & 54,73 & 54,40 & 55,07 & 0,81 & 0,996 & 0,945 \\
\hline $\mathrm{CNF}$ & 74,81 & 76,44 & 76,04 & 0,85 & 0,334 & 0,812 \\
\hline \multicolumn{7}{|c|}{ Consumo \% PV } \\
\hline Matéria seca & 4,28 & 4,18 & 3,99 & 0,09 & 0,035 & 0,069 \\
\hline FDN & 1,38 & 1,40 & 1,47 & 0,02 & 0,101 & 0,057 \\
\hline
\end{tabular}

${ }^{1}$ Controle (C); grão de soja (GS); caroço de algodão (CA); ${ }^{2}$ Erro padrão da média; ${ }^{3}$ Contrastes ortogonais: Controle vs semente oleaginosa $(\mathrm{C} 1)$; grão de soja vs caroço de algodão $(\mathrm{C} 2)$.

As vacas alimentadas com sementes oleaginosas tiveram ingestão média diária de $350 \mathrm{~g}$ EE a mais que os animais alimentados com dieta $\mathrm{C}(\mathrm{P}<0,05)$. Este efeito é esperado devido ao aumento dos teores de EE quando são adicionadas sementes oleaginosas nas dietas. Resultado semelhante ao de Fernandes et al. (2002), que observaram aumento linear no consumo de EE com a inclusão de caroço de algodão ( 6,0 12,0 18,0 e 24,0 \% MS) nas dietas 
de vacas Holandesas, pois o aumento na concentração de EE proporcionado pela inclusão do CA na dieta também superou a redução do CMS. Também houve efeito para consumo de EE quando se analisou as sementes oleaginosas $(\mathrm{C} 2)(\mathrm{P}<0,05)$, os animais alimentados com a dieta GS consumiram média de $160 \mathrm{~g}$ a mais de EE ao em relação aos animais que consumiram CA. O grão de soja cru integral teve maior teor de EE em sua composição (Tabela 1), além dos animais alimentados com GS terem maior CMS $(\mathrm{P}<0,05)$ que os alimentados com CA, levando a uma maior ingestão de EE.

Não foi observada diferença no consumo de FDN e consumo de FDN expresso em porcentagem de peso vivo tanto nos animais que consumiram a dieta controle e as que tiveram inclusão de sementes oleaginosas, assim como não houve diferença entre os alimentados com sementes (Tabela 4). Este resultado se deve a maior quantidade deste nutriente na dieta CA (Tabela 3), que mesmo com menor CMS, mantiveram o consumo de FDN.

As vacas alimentadas com oleaginosas apresentaram digestibilidade cerca de 3,0\% maior da fração de $\mathrm{EE}(\mathrm{P}<0,05)$. Não houve diferença na digestibilidade entre as dietas contendo sementes. Este aumento sugere que lipídeos tem digestibilidade maior quando inclusos na dieta em teores maiores que a dieta basal. O tamanho da cadeia do ácido graxo utilizado, assim como seu grau de insaturação tem correlação positiva com a digestibilidade observada no EE (NRC, 2001).

Analisando a inclusão de caroço de algodão entre 0,9 e $5,1 \mathrm{~kg} /$ dia na dieta de vacas em lactação, Smith et al. (1981) observaram que a medida em que aumentou a ingestão de EE, ocorreu um efeito linear crescente em sua digestibilidade. Com resultados semelhante ao estudo de Fernandes et al. (2002) onde o coeficiente de digestibilidade do EE também aumentou linearmente com o aumento do consumo de EE.

Não houve efeito das dietas sobre a digestibilidade da MS e MO. Palmquist e Corand (1991) propuseram redução de 2,2\% na digestibilidade da MS para cada 100g de lipídeos consumida e também sugeriram que essa redução ocorre linearmente com o aumento dos lipídeos na dieta em vacas lactação. Jenkins e Jenny (1989) consideraram que o lipídeo acrescentado a dieta geralmente diminui e, em alguns casos, tem efeito mínimo sobre a digestibilidade da matéria seca. Também não houve efeito da digestibilide da proteína bruta (PB) entre as dietas experimentais, sendo o mesmo resultado observado por outros autores que incluíram sementes oleaginosas nas dietas (PALMQUIST; CONRAD, 1980; BERNARD, 1990; WU et al., 1994; RABELO, 1996). 
Mesmo com a inclusão de lipídeos não houve redução na digestibilidade da FDN quando comparado à dieta controle com as dietas contendo sementes oleaginosas. Assim como o estudo de $\mathrm{Wu}$ et al. (1993) que analisaram dietas para vacas em lactação contendo diferentes fontes de ácidos graxos, sem influenciar a digestibilidade da FDN. Outros autores descreveram (SMITH et al., 1981; WU et al., 1994) que não observaram influência dos lipídeos quando incluídos na forma de sementes na digestibilidade da FDN. Isso ocorre possivelmente porque o uso de sementes oleaginosas proporcionaria menor efeito dos lipídeos sobre a digestibilidade de nutrientes por proporcionar lenta liberação de lipídios no rúmen, não superando a capacidade de hidrogenação dos microrganismos ruminais e impedindo possível perda de digestibilidade de fibra pelo efeito negativo que lipídeos insaturados prontamente disponíveis no rúmen podem causar nas bactérias fibrolíticas (COPPOCK; WILKS, 1991; PALMQUIST, 1991).

$\mathrm{O}$ consumo de nutrientes digestíveis totais foi maior na dieta GS que na dieta CA $(\mathrm{P}<0,05)$, em consequência do maior CMS (Tabela 4) junto ao maior valor de NDT da dieta contendo grão de soja (Tabela 3) o que possibilitou aos animais alimentados com essa dieta uma maior ingestão de energia.

\subsection{FERMENTAÇÃO RUMINAL}

Os efeitos das dietas experimentais sobre os parâmetros fermentativos podem ser vistos na tabela 5 . 
Tabela 5 - Parâmetros de fermentação ruminal de vacas lactantes alimentadas com inclusão de sementes oleaginosas ou não

\begin{tabular}{|c|c|c|c|c|c|c|c|}
\hline \multirow[b]{3}{*}{ parâmetros } & \multicolumn{3}{|c|}{ DIETA $^{1}$} & & \multicolumn{3}{|c|}{ Probabilidadade $\left(P^{3}\right)$} \\
\hline & $\mathrm{C}$ & GS & $\mathrm{CA}$ & & Tempo & Dieta & INT D*T \\
\hline & \multicolumn{7}{|c|}{$\mathrm{EPM}^{2}$} \\
\hline $\mathrm{pH}$ & 6.314 & 6.170 & 6.459 & 0.068 & $<0.001$ & 0.999 & 0.035 \\
\hline $\mathrm{N}-\mathrm{NH}_{3}$ & 31.977 & $\begin{array}{l}m g / d L \\
24.564\end{array}$ & 30.016 & 1.253 & 0.002 & 0.120 & 0.003 \\
\hline Acetato & 99.451 & $\begin{array}{c}\text { Mmol } \\
89.601\end{array}$ & 84.223 & 3.341 & 0.084 & 0.333 & 0.163 \\
\hline Propionato & 27.306 & 33.260 & 29.140 & 1.330 & 0.069 & 0.583 & 0.007 \\
\hline Butirato & 15.811 & 13.920 & 11.777 & 0.516 & 0.093 & 0.198 & 0.190 \\
\hline AGCC & 147.120 & 139.490 & 125.620 & 4.560 & 0.290 & 0.539 & 0.092 \\
\hline & & $\% A G C C)$ & & & & & \\
\hline Acetato & 69.752 & 65.278 & 67.749 & 0.603 & 0.003 & 1.000 & 0.201 \\
\hline Propionato & 19.097 & 24.462 & 22.808 & 0.582 & 0.079 & 0.214 & 0.111 \\
\hline Butirato & 11.151 & 10.260 & 9.444 & 0.187 & $<0.001$ & $<0.001$ & 0.047 \\
\hline & & Relação & & & & & \\
\hline $\mathrm{C} 2: \mathrm{C} 3$ & 2.635 & 2.480 & 2.238 & 0.068 & 0.002 & 0.235 & 0.382 \\
\hline
\end{tabular}

Observamos efeito da dieta dependente do tempo sobre o $\mathrm{pH}$ ruminal $(\mathrm{P}<0,05)$, nos tempos 2,4 e 6 horas após a alimentação nas vacas consumindo dietas com inclusão de sementes oleaginosas. Os animais que consumiram dieta CA tiveram o seu valor médio de $\mathrm{pH}$ 0,44; 0,36 e 0,62, maiores em relação aos animais da dieta GS, respectivamente (Figura 1).

Vários fatores podem estar associados a este efeito, como a capacidade da dieta de estimular a ruminação, características do alimento e o consumo de matéria seca e nutrientes. O caroço de algodão contem línter, que se estratifica melhor pelo rúmen, estimula a mastigação e ruminação, contribuindo para o tamponamento (COPPOCK; LANHAM; HORNER, 1987). Também o CMS foi 5,0 \% maior nos animais recebendo dieta GS, estes 
também tiveram maior consumo de $\mathrm{CNF}(\mathrm{P}<0,05)$, com ingestão média de $1,44 \mathrm{~kg}$ a mais em relação aos animais que consumiram a dieta CA (Tabela 4) e podem explicar esta diferença.

Figura 1 - Efeito das dietas experimentais sobre o $\mathrm{pH}$ ruminal, nos diferentes tempos

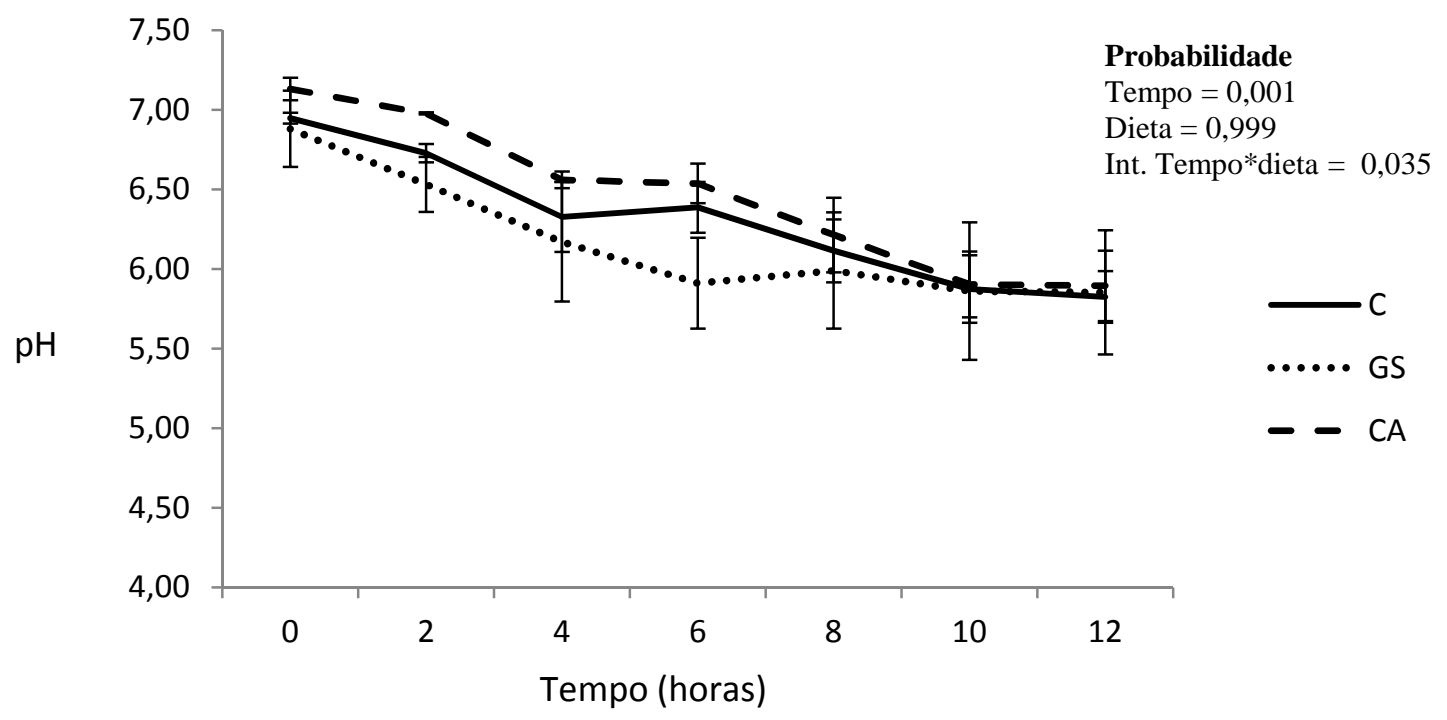

Abel-Caines et al. (1997) analisaram o tempo de ruminação em vacas da raça Holandesa alimentadas com silagem de milho e comparavam a inclusão de caroço de algodão (15,0 \% na MS da dieta) com uma mistura de grão de soja cru com casca de soja (15,0 e 8,0 $\%$ na MS da dieta, respectivamente). Observaram tempo médio de $85 \mathrm{~min} /$ dia a mais de mastigação dos animais que se alimentavam com dieta contendo caroço de algodão. Esta maior atividade de mastigação contribui para o tamponamento ruminal, no qual observaram produção de cerca de 23,5 L/dia a mais de saliva pelos animais alimentados com caroço de algodão. Ainda segundo os autores, a composição média da saliva contem $6 \mathrm{~g} / \mathrm{L}$ de bicarbonato de sódio. Deste modo, teríamos aproximadamente $140 \mathrm{~g}$ a mais de bicarbonato disponível para o tamponamento do rúmen dos animais alimentados com caroço de algodão em relação aos alimentados com soja.

No estudo de Fernandes et al. (2002), independentemente do tempo, não houve diferença dos diferentes teores de inclusão de CA nas dietas sobre o pH ruminal, uma vez que o CMS foi de 16,0 kg/dia, bem abaixo do resultado observado no presente estudo. Coppock (1985), utilizando silagem de milho e diferentes teores de CA, não encontraram diferença no pH ruminal. Segundo Furlan et al. (2006), valores de pH entre 5,5 a 7,0 são considerado normais e otimizam a taxa de digestão ruminal e a degradação da parede celular da fibra. 
Considerando que os valores médios de $\mathrm{pH}$ obtidos neste estudo variaram entre 5,8 e 7,1 (Figura 1) podemos concluir que os animais se encontravam dentro dos valores considerados fisiologicamente normais.

Houve interação entre dieta e tempo para variável $\mathrm{N}-\mathrm{NH}_{3}$ no rúmen $(\mathrm{P}<0,05)$. No tempo 6 horas, as vacas que foram alimentadas com a dieta GS apresentaram menor concentração de $\mathrm{N}_{-} \mathrm{NH}_{3}$ no rúmen em relação as dietas $\mathrm{CA}$ e $\mathrm{C}$ que não diferiram entre si $(25,81$ e $42,50 \mathrm{mg} / \mathrm{dL}$ respectivamente).

No tempo 10 horas, o $\mathrm{N}-\mathrm{NH}_{3}$ ruminal da dieta GS diferiu $(\mathrm{P}<0,05)$ da dieta $\mathrm{C}$, em $21,65 \mathrm{mg} / \mathrm{dL}$. O N-NH 3 ruminal é originado da degradação proteica da dieta, e de fontes de nitrogênio não-proteico, ureia reciclada no rúmen e da lise da proteína microbiana (SATTER; SLYTER, 1974; LENG; NOLAN, 1984; RUSSELL et al., 1992). O volume de proteína degradável no rumen produzido nas vacas alimentadas com inclusão de grão de soja foi maior. O teor de PB do grão de soja (39,25\%;) é maior que o do caroço de algodão (20\%) assim como seu teor de PNDR (73\%; 69\%, respectivamente). Sendo assim, para formular dietas para vacas de alta produção para serem isoPDR e isoPNDR, é necessário a inclusão de proteína verdadeira, de liberação mais lenta, na dieta GS e inclusão de ureia nas demais $\operatorname{dietas}(0,057 \mathrm{~g} / \mathrm{kg}$ de MS)

Figura 2 - Efeito das dietas experimentais sobre a concentração de N-NH3 ruminal, nos diferentes tempos

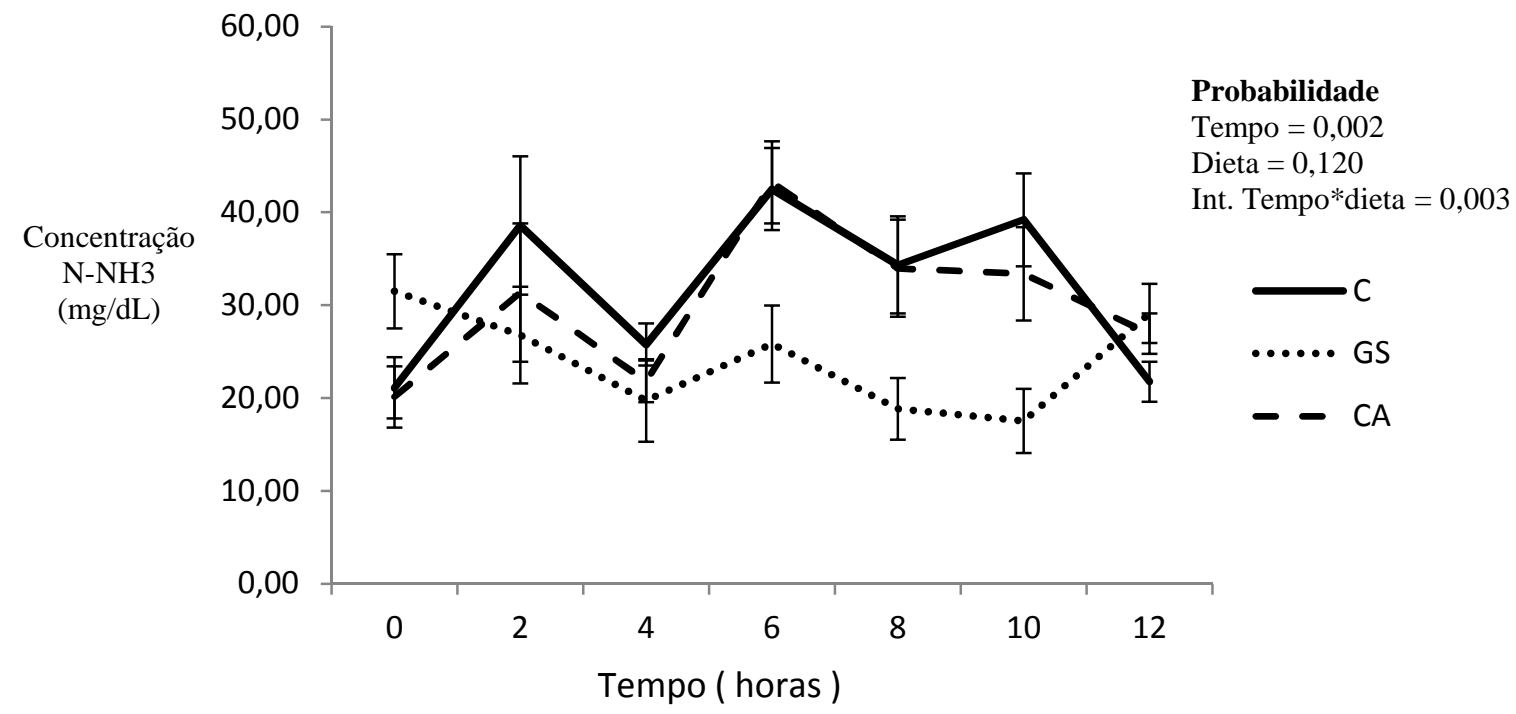

Maiores diferenças foram observadas logo após picos de consumo, onde as concentrações de $\mathrm{N}-\mathrm{NH}_{3}$ foram mais altas nas dietas CA e C. Como a ureia é uma fonte de 
nitrogênio não proteico de rápida liberação no rúmen, isso pode ter levado a maior concentração de $\mathrm{N}-\mathrm{NH}_{3}$ nas vacas alimentados com a sua inclusão na dieta.

Barletta (2010), em estudo realizado com diferentes teores de inclusão de grão de soja na dieta de vacas no terço médio de lactação, foram coletadas amostras de líquido ruminal com a utilização de sonda esofágica três horas após a alimentação da manhã e observou concentração de $\mathrm{N}-\mathrm{NH}_{3}$ no rúmen maior $(\mathrm{P}<0,05)$ para os animais que consumiram a dieta controle em relação às dietas contendo grão de soja cru integral, que não diferiram entre si. Segundo Barletta (2010) o grão de soja integral é mais resistente a degradação ruminal que a ureia, proporcionando nas dietas onde houve a inclusão do grão de soja menores valores de N$\mathrm{NH}_{3}$ no rúmen.

As médias das concentrações de N-NH3 ruminal foram superiores aos $20 \mathrm{mg} / \mathrm{dL}$ sugeridos por Mehrez et al. (1977) para animais em produção para garantir a maximização da fermentação microbiana (LENG, 1990). Analisando três inclusões (7,0; 14,0 e 21,0 \% na MS da dieta) de caroço de algodão na dieta de vacas lactante, Martinez (2008) observou que o tratamento com maior inclusão de caroço de algodão (21,0 \% MS) apresentou maiores concentrações de amônia (40,66 mg/dL). A dieta com inclusão de 14\% (MS) de caroço de algodão apresentou valores intermediários $(36,45$ e $35,38 \mathrm{mg} / \mathrm{dL})$ e a dieta com menor inclusão (7,0 \% MS) e dieta controle (sem inclusão de sementes) não diferiram, apresentando valores médios de 33,63 e 30,2 mg/dL.

$\mathrm{O} \mathrm{N}_{-} \mathrm{NH}_{3}$ é utilizado pelos microrganismos e o excedente absorvido pela parede do rúmen e transportado para o fígado, entrando no ciclo da ureia, que pode ser reciclada ou eliminada (VAN SOEST, 1994). Apesar das diferenças observadas para a concentração ruminal de $\mathrm{N}-\mathrm{NH}_{3}$, a concentração de ureia sanguínea dos animais não foi influenciada pelas dietas ( $\mathrm{P}>0,05)$ (Tabela 10). No entanto, a diminuição dos níveis de $\mathrm{N}-\mathrm{NH}_{3}$ encontrados nas dietas com grão de soja não implicou em prejuízos aos microrganismos ruminais (BARLETTA, 2010).

Não se observou interação entre as dietas avaliadas e o tempo para as concentrações em Mmol/L de ácido acético, propiônico, butírico e AGCC total (Figuras 3, 4, 5 e 6). A moderada inclusão de lipídeos (cerca de 4,5\% de EE na dieta) junto a lenta liberação deste nutriente quando incluso nestes alimentos não afetou a produção dos AGCC.

Assim como no presente estudo, Fernades et al. (2002), utilizando diferentes teores de caroço de algodão não observaram diferença na concentração de AGCC total quanto ao efeito dos tratamentos e da interação deste com o tempo. Pires et al. (1997) também observaram 
resultados semelhantes ao do presente estudo, avaliando o efeito da inclusão caroço de algodão (18,0\% na MS da dieta), processado física e termicamente, sobre a concentração de ácido propiônico.

As dietas não alteraram as proporções de ácido acético, propiônico e a relação acetato:propionato (Tabela 5). Este resultado é reflexo da digestibilidade da FDN, (Tabela 4) que não foi afetada pelas dietas. De modo semelhante, Mohamed (1988) avaliou a inclusão de óleo livre, grão de soja cru e caroço de algodão na alimentação de oito vacas da raça Holandesa, canuladas no rúmen. Não encontrando diferença na concentração de AGCC entre as sementes oleaginosas avaliadas e a dieta controle. Apenas a dieta contendo óleo livre diferiu das demais, levando a menores resultados para esta variável. Anderson, Adams e Lamb (1979) trabalhando com vacas raça Holandesa com CMS de 18,13 kg/dia, sendo 2,0 kg/dia de caroço de algodão e produção de leite de 25,70 L/dia, não encontraram diferença na porcentagem dos ácidos graxos de cadeia curta (AGCC) e na relação acetato: propionato. Fernades et al. (2002) também não observaram diferença na relação acético:propiônico para o efeito de tratamento e tampouco para a interação tratamento x tempo.

Houve diferença na proporção de acido butírico (Tabela 5) onde foi observado menor valor nas vacas que foram alimentados com caroço de algodão, o que pode ser explicado pelo menor consumo de matéria seca dos animais submetidos a esta dieta.

Figura 3 - Efeito das dietas experimentais sobre a produção de acido acético ruminal nos diferentes tempos

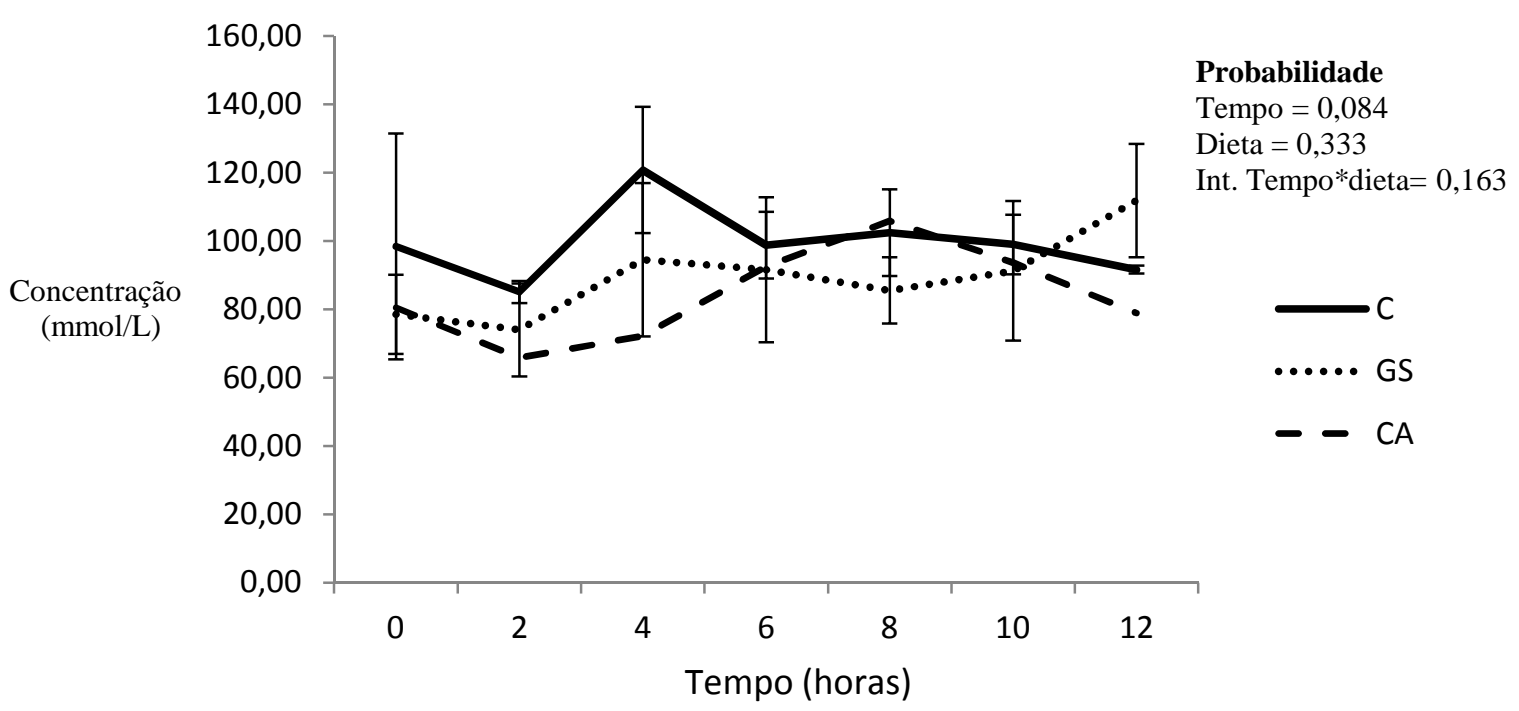


Figura 4 - Efeito das dietas experimentais sobre a produção de ácido propiônico ruminal nos diferentes tempos

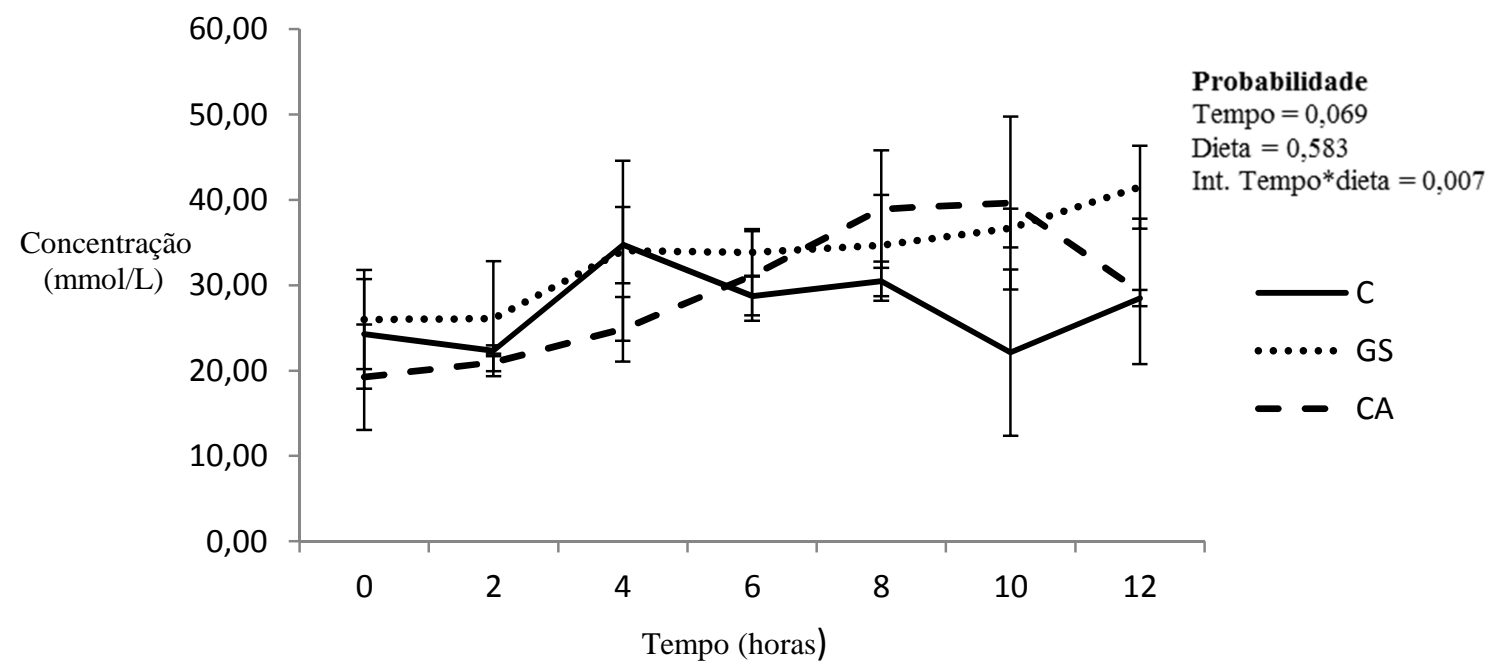

Figura 5 - Efeito das dietas experimentais sobre a produção de acido butirico ruminal nos diferentes tempos

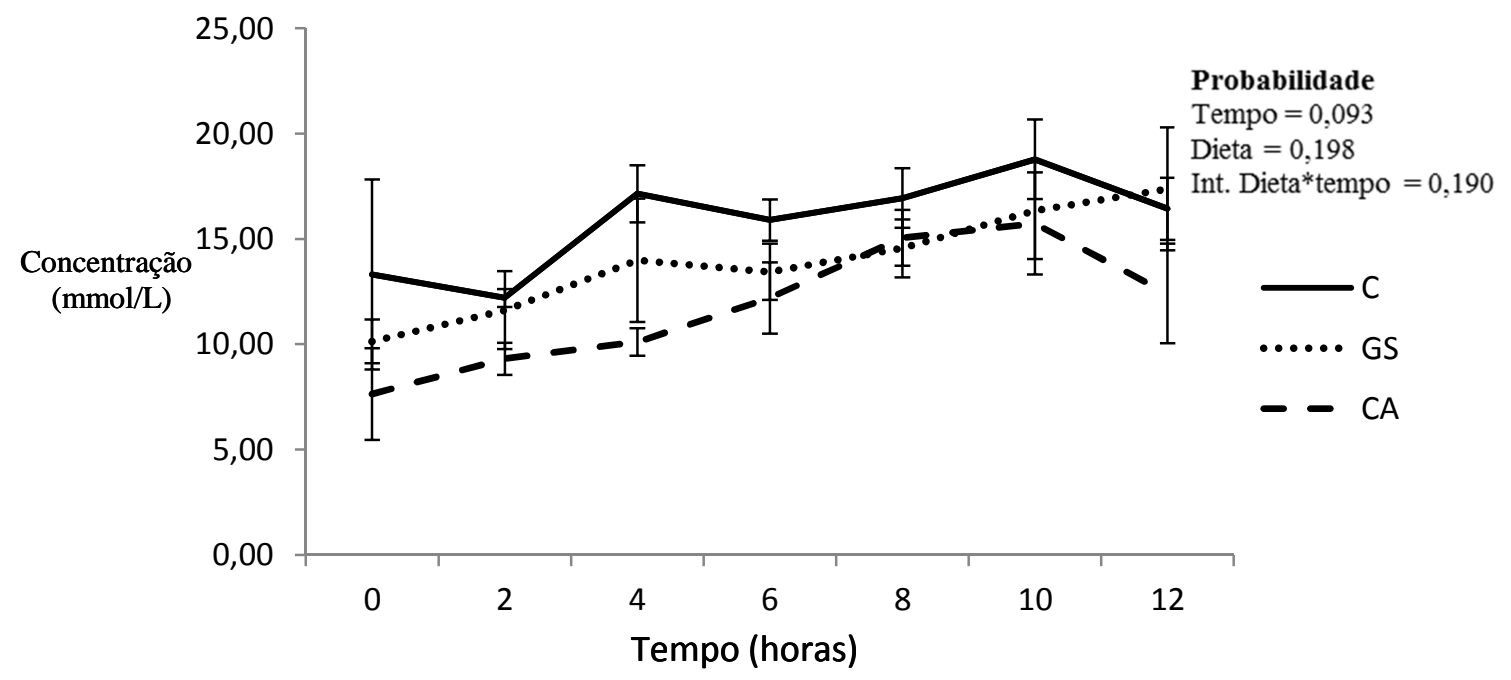


Figura 6 - Efeito das dietas experimentais sobre a produção total de ácidos graxos de cadeia curta nos diferentes tempos

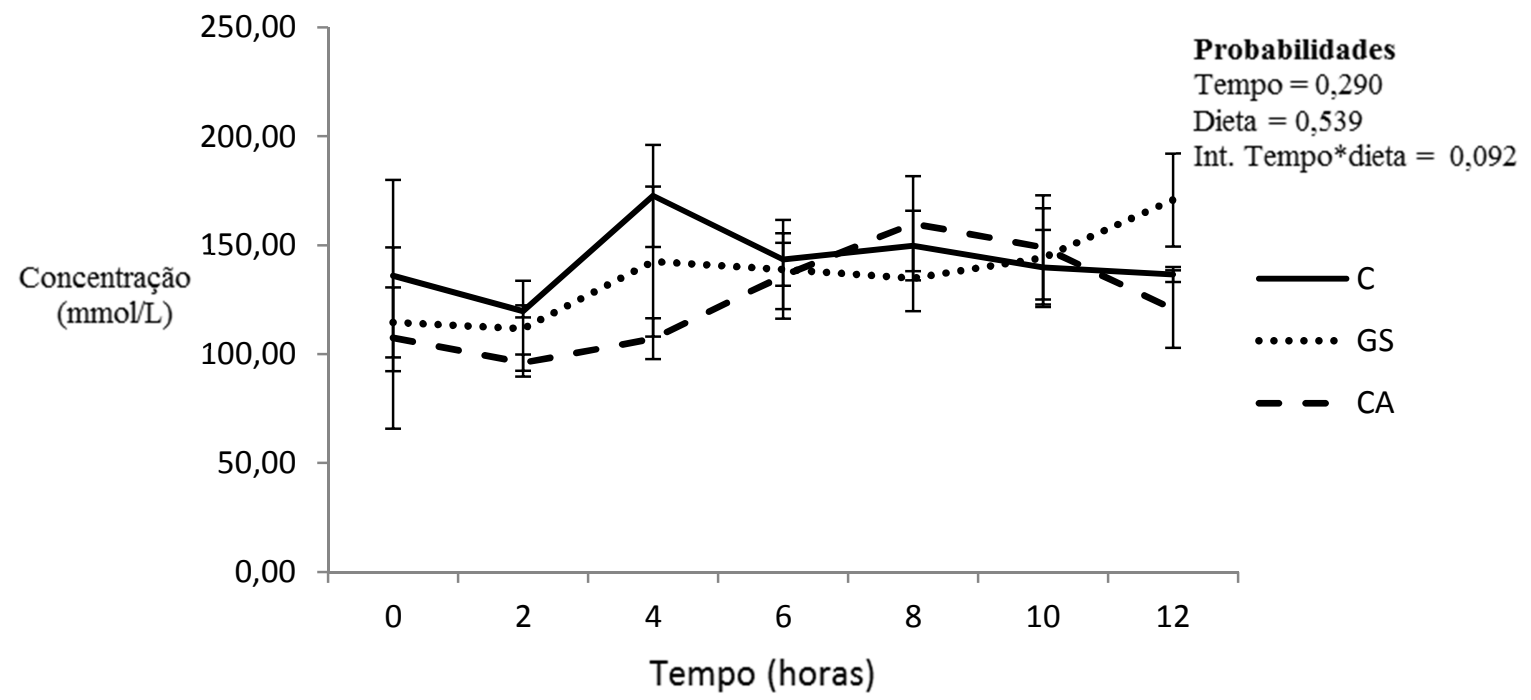

Sendo assim, analisando em conjunto a digestibilidade aparente total dos nutrientes e fermentação ruminal obtidos neste estudo, verifica-se que a inclusão de grão de soja ou caroço de algodão, no teor de $12 \%$ na MS da dieta, não afeta negativamente o metabolismo ruminal.

\subsection{SINTESE DE PROTEINA MICROBIANA RUMINAL}

Não foram observadas diferenças nas excreções diárias em Mmol/L e Mmol/dia de alantoína na urina e no leite, e ácido úrico na urina e para a produção de urina em L/dia entre as dietas experimetais (Tabela 6). Não houve diferença entre as vacas alimentadas com dieta $\mathrm{C}$ e as dietas contendo sementes oleaginosas, assim como entre as dietas contendo suplementação lipídica $(\mathrm{P}>0,05)$ nas concentrações das purinas totais e purinas absorvíveis em Mmol/dia, e para a produção de nitrogênio microbiano e proteína bruta microbiana, em g/dia (Tabela 6). Portanto não foi observada diferença na eficiência da síntese de proteína microbiana dos animais alimentados com dietas contendo ou não sementes oleaginosas.

A proteína microbiana tem impacto significativo na quantidade e qualidade da proteína metabolizável absorvida no intestino delgado, pois a proteína dietética com baixa degradabilidade ruminal pode ter menor digestibilidade que a proteína microbiana no intestino 
delgado, que, por sua vez, apresenta perfil de aminoácidos próximo exigido pelo animal (O’CONNOR et al., 1993).

Tabela 6 - Síntese de proteína microbiana de vacas lactantes alimentadas com inclusão de sementes oleaginosas ou não

\begin{tabular}{|c|c|c|c|c|c|c|}
\hline \multirow{2}{*}{ Parâmetros 4} & \multicolumn{3}{|c|}{ Dietas } & \multirow{2}{*}{$\mathrm{EPM}^{2}$} & \multicolumn{2}{|c|}{$P^{2}$} \\
\hline & $\mathrm{C}$ & GS & $\mathrm{CA}$ & & $\mathrm{C} 1$ & $\mathrm{C} 2$ \\
\hline \multicolumn{7}{|c|}{$\mathrm{Mmol} / \mathrm{l}$} \\
\hline Al-leite & 0,03 & 0,04 & 0,04 & 0,01 & 0,142 & 0,446 \\
\hline Al-urina & 22,60 & 23,00 & 23,62 & 0,57 & 0,5277 & 0,6391 \\
\hline Ác-úrico & 1,85 & 2,44 & 1,86 & 0,15 & 0,2665 & 0,069 \\
\hline
\end{tabular}

\section{Mmol/dia}

\begin{tabular}{|c|c|c|c|c|c|c|}
\hline Al-leite & 1,20 & 1,45 & 1,22 & 0,06 & 0,288 & 0,108 \\
\hline Al-urina & 332,77 & 319,30 & 320,36 & 7,21 & 0,406 & 0,953 \\
\hline Ác-úrico & 36,84 & 44,13 & 32,26 & 3,22 & 0,891 & 0,096 \\
\hline $\mathrm{Pt}$ & 407,52 & 384,16 & 390,82 & 7,90 & 0,235 & 0,731 \\
\hline Pabs & 499,27 & 479,36 & 474,00 & 11,40 & 0,356 & 0,874 \\
\hline & & g/dia & & & & \\
\hline $\mathrm{N}$ mic & 314,23 & 301,7 & 298,96 & 6,94 & 0,357 & 0,650 \\
\hline $\mathrm{Pb}$ mic & 1963,96 & 1885,64 & 1868,47 & 40,91 & 0,356 & 0,87 \\
\hline
\end{tabular}

\section{g Pbmic/Kg NDT}

Eficiência $\quad 111,99 \quad 107,21 \quad 111,60 \quad 2,51 \quad 0,641 \quad 0,493$

\section{L/dia}

$\begin{array}{lllllll}\text { Urina } & 19,14 & 17,76 & 17,20 & 1,3 & 0,277 & 0,749\end{array}$

${ }^{1}$ Controle (C); grão de soja (GS); caroço de algodão (CA); ${ }^{2}$ Erro padrão da média; ${ }^{3}$ Contrastes ortogonais: Controle vs semente oleaginosa (C1); grão de soja vs caroço de algodão (C2); ${ }^{4}$ Alantoína no leite (Al-leite), alantoína na urina (Al-urina), ácido úrico (Ác-úrico), purinas totais $(\mathrm{Pt})$, derivados de purinas $(\mathrm{Dp})$, purinas absorvíveis (Pabs), nitrogênio microbiano ( $\mathrm{N}$ mic), proteína microbiana $(\mathrm{Pb}$ mic)

De acordo com Palmiquist (1993), a eficiência microbiana como consequência da utilização de lipídeos pode ser comprometida pela redução da quantidade de carboidratos rapidamente fermentáveis, reduzindo dessa forma a quantidade de substrato disponível para síntese de proteína microbiana (SPM) Entretanto, assim como neste estudo, alguns estudos encontrados na literatura não demonstram tais resultados. 
Freitas Júnior et al. (2010) avaliaram a excreção dos derivados de purina, nitrogênio microbiano total e proteína microbiana em dietas com a inclusão de $16 \%$ de grão de soja cru na matéria seca das dietas e não encontraram diferença para as demais dietas avaliadas, sendo os valores observados pelos autores são semelhantes aos encontrados no presente estudo.

Barletta (2010) não observou alteração na síntese de proteína microbiana utilizando até 24,0\% (MS) de inclusão de grão de soja cru e integral nas dietas de vacas raça Holandesa. Os animais alimentados com maior inclusão da semente tiveram ingestão média de $1,2 \mathrm{~kg}$ a menos de CNF por dia em relação aos animais tratados com dieta controle. Sendo observada uma média de 269,90 g/dia de nitrogênio microbiano, número próximo ao deste estudo que teve média de 304,2 g/dia. De forma semelhante, Melo et al. (2007), analisando vacas da raça Holandesas, consumindo palma forrageira como fonte volumosa, testaram a inclusão de até $25,0 \%$ de caroço de algodão na dieta total e não encontraram diferença na síntese de nitrogênio microbiano que teve média de 295,08 próxima a do presente estudo.

Os resultados demostram que o grão de soja ou o caroço de algodão, são opções de fonte de nitrogênio na alimentação de vacas lactantes já que não foi observado efeito sobre a síntese de proteína microbiana quando na utilização das sementes em até $12,0 \%$ na MS da dieta.

\subsection{PRODUÇÃO E COMPOSIÇÃO DO LEITE}

Não foi observado efeito entre as dietas sobre a produção de leite, produção de leite corrigida, teor e produção de gordura, proteína, lactose e eficiência de conversão entre CMS e produção de leite (Tabela 7). Esses resultados indicam que possivelmente o aporte de nutrientes para o animal e especialmente para a glândula mamária não foi limitado em nenhuma das dietas. Também não houve efeito das dietas na produção e composição do leite quando comparamos os animais que foram suplementados com sementes mesmo com menor CMS ( $\mathrm{P}<0,05)$ (Tabela 4) das vacas alimentadas com dieta CA, estas tiveram supridas as suas exigências de $E_{L}$ permitindo assim que estes animais mantivessem a sua produção. Os resultados obtidos neste estudo estão de acordo com a maioria dos estudos revisados na literatura, nos quais inclusões intermediárias de grão de soja ou caroço de algodão não afetaram a produção de leite (SMITH et al., 1981; SMITH; HARRIS, 1992; VILLELA 1995; 
MORA; LEÃO; VALADARES FILHO, 1996; FREITAS JUNIOR, 2010; BARLETTA, 2010; VENTURELLI, 2011).

Tabela 7 - Produção e composição do leite de vacas lactantes alimentadas com inclusão de sementes oleaginosas ou não

\begin{tabular}{|c|c|c|c|c|c|c|}
\hline \multirow{2}{*}{ Parâmetros } & \multicolumn{3}{|c|}{ Dietas $^{1}$} & \multirow{2}{*}{$\mathrm{EPM}^{2}$} & \multicolumn{2}{|c|}{$P^{3}$} \\
\hline & $\mathrm{C}$ & GS & $\mathrm{CA}$ & & $\mathrm{C} 1$ & $\mathrm{C} 2$ \\
\hline \multicolumn{7}{|c|}{$\mathrm{kg} / \mathrm{dia}$} \\
\hline Produção de leite & 31,57 & 31,44 & 30,65 & 0,69 & 0,576 & 0,467 \\
\hline Produção de leite corrigida & 33,78 & 33,91 & 33,13 & 0,72 & 0,828 & 0,574 \\
\hline Gordura & 1,23 & 1,24 & 1,22 & 0,03 & 0,963 & 0,717 \\
\hline Proteína & 0,95 & 0,96 & 0,92 & 0,02 & 0,645 & 0,265 \\
\hline Lactose & 1,43 & 1,42 & 1,39 & 0,03 & 0,559 & 0,541 \\
\hline Eficiencia $^{4}$ & 1,31 & 1.36 & 1,36 & 0,02 & 0,134 & 0,806 \\
\hline \multicolumn{7}{|c|}{ Porcentagem } \\
\hline Gordura & 3,94 & 3,97 & 4,03 & 0,08 & 0,482 & 0,793 \\
\hline Proteína & 3,02 & 3,05 & 3,02 & 0,01 & 0,707 & 0,102 \\
\hline Lactose & 4,55 & 4,53 & 4,54 & 0,02 & 0,631 & 0,413 \\
\hline
\end{tabular}

1Controle (C); grão de soja (GS); caroço de algodão (CA); 2 Erro padrão da média;3 Contrastes ortogonais: Controle vs semente oleaginosa (C1); grão de soja vs caroço de algodão (C2); 4 Produção de leite por kg de MS consumido.*Médias ajustadas pelo LSMEANS do PROC MIXED do SAS 9.0

Em estudo com diversos teores de caroço de algodão na dieta de vacas em lactação Sullivan et al. (2004) não observaram diferença na produção de leite (32 kg/dia) e teor de gordura (3,5\%). Mesmo com maior inclusão (15,0\% da MS da dieta), Costa et al. (2011) não encontraram diferença na produção de leite e teor de gordura de vacas mestiças. Resultados de igual natureza, utilizando grão de soja foram observados por Deresz et al. (1996), onde a soja crua, triturada grosseiramente na dieta, foi incluída na alimentação de vacas da raça Holandesa em início de lactação, com média de produção de 28,0 kg/dia. não foram observados efeitos da utilização de até $24,0 \%$ de grão de soja moído grosseiramente na dieta sobre a produção e composição do leite, CMS e nutrientes. Estes resultados são semelhante aos de Barletta (2010) também não observou efeito das dietas sobre a produção de leite $(31,21$ $\mathrm{kg} /$ dia) e produção de leite corrigido (29,26 kg/dia) em dietas com inclusão de até $16,0 \%$ de grão de soja cru integral na MS da dieta de vacas raça Holandesa. 
Alguns tipos de lipídeos acrescentados à dieta podem alterar a composição e as características físico-químicas do leite, como no caso daquelas com elevado teor de ácidos graxos insaturados (NRC, 2001). Fatores como nível de inclusão de sementes, tipo de forragem da dieta e tamanho da partícula influenciam a depressão ou não da gordura do leite com o uso de lipídeos e várias teorias tem sido formuladas para explicar este efeito, que são mais intensos quando se faz uso de óleo livre (BAUMGARD et al., 2002). A redução do teor de gordura do leite obtido com suplementação lipídica com fontes contendo ácidos graxos insaturados se relaciona aos efeitos dos ácidos graxos intermediários resultantes do processo de biohidrogenação ruminal sobre a síntese de novo de gordura na glândula mamária. Esta redução na síntese de gordura do leite está bem documentada na literatura, conforme citaram Bauman e Griinari (2001).

Estas hipóteses não são evidenciadas neste estudo, uma vez que a inclusão moderada de extrato etéreo (4,5\% MS) na dieta na forma de sementes oleaginosas, não influenciou a digestibilidade da fibra, produção e teor de gordura no leite. Desta forma pode-se constatar que a proteção física do óleo feita pela semente pode ter mínimizado os efeitos deletérios sobre a produção de gordura no leite.

Já os animais alimentados com a dieta CA tiveram sua produção e porcentagem de gordura no leite mantidas em relação aos outras dietas, mesmo com menor CMS, o que pode estar associado a característica de sua fibra. Segundo Clark e Armentano (1993) a efetividade do FDN do caroço de algodão é equivalente ao do feno de alfafa, e é capaz de substituir forrageira como fonte de fibra efetiva (STERN; ZIEMER, 1992; CLARK; ARMENTANO, 1993) aumentando o tempo de ruminação dos animais que a recebem na dieta (CLARK; ARMENTANO, 1993), possivelmente mantendo os níveis de produção dos precursores da gordura do leite.

Mohamed et al. (1988) analisaram diferentes formas de processamento do caroço de algodão e grão de soja na alimentação de vacas em lactação. Assim como neste estudo, a produção das vacas alimentadas com as sementes mantiveram a produção de leite $(27,0$ $\mathrm{kg} / \mathrm{dia})$, leite corrigido $(25,0 \mathrm{~kg} / \mathrm{dia})$, teor e produção de gordura e proteína em relação à dieta controle.

Pires et al. (1996) observaram redução no teor de proteína do leite com a inclusão de $18,0 \%$ de soja tostada inteira ou moída na dieta de vacas lactantes. Tal fato pode estar associado ao menor aporte de aminoácidos essenciais ao intestino delgado em comparação ao farelo de soja (SNIFFEN et al., 1992), ou por uma menor disponibilidade de aminoácidos na 
glândula mamária (WU; HUBER, 1994). No presente estudo, tal efeito não foi observado uma vez que não houve diferença entre as dietas para a síntese de proteína microbiana (Tabela 6) assim como para a eficiência, produção e porcentagem de proteína no leite (Tabela 7), mostrando que tanto o grão de soja cru integral quanto o caroço de algodão podem ser incluídos em dietas de vacas com produção média de $31,22 \mathrm{~kg} /$ dia sem perdas produtivas.

\subsection{BALANÇO DE ENERGIA}

Podemos observar que não houve efeito no consumo de energia bruta, digestível, metabolizável e líquida para lactação, além do balanço de energia quando comparamos estas variáveis entre os animais que foram suplementados com sementes oleaginosas e os alimentados com dieta controle. Estes resultados podem ser explicados pelo CMS e CEE, onde o menor CMS $(\mathrm{P}<0,05)$ (Tabela 4) dos animais alimentados com sementes oleaginosas foi energeticamente compensado pelo maior CEE $(\mathrm{P}<0,05)$ (Tabela 4). Como os lipídeos possuem 2,25 vezes mais energia que carboidratos e proteínas, ocorreu pela maior inclusão de energia nas dietas contendo sementes oleaginosas (Tabela 3), levando a esta igualdade no consumo energético.

Analisando as vacas alimentadas com dietas contendo sementes, foi observado efeito $(\mathrm{P}<0,05)$ no consumo de energia liquida para lactação. Os animais alimentados com a dieta GS consumiram em média, 9,47\% de $\mathrm{EL}_{\mathrm{L}}$ a mais que as vacas da dieta $\mathrm{CA}$. $\mathrm{O}$ aumento no consumo médio foi de 3,61Mcal/dia e esta diferença é referente ao maior CMS e CEE $(\mathrm{P}<0,05)$ (Tabela 4) considerando que a dieta GS tem $2,0 \%$ a mais que a dieta $\mathrm{CA}$.

No presente estudo, os animais obtiveram ganho de peso diário médio de 0,480 kg/dia, este ganho de peso se deve ao fato das dietas terem atendido as necessidades de mantença e produção. Analisando as sementes oleaginosas, foi observado efeito $(\mathrm{P}<0,05)$ para balanço de energia. As vacas alimentadas com GS tiveram em media, 3,56 Mcal/dia a mais de energia de ganho do que os animais que se alimentaram com CA. 
Tabela 8 - Balanço de energia de vacas lactantes alimentadas com inclusão de sementes oleaginosas ou não

\begin{tabular}{|c|c|c|c|c|c|c|}
\hline \multirow{2}{*}{ Parâmetros } & \multicolumn{3}{|c|}{ Dietas experimentais $^{1}$} & \multirow{2}{*}{$\mathrm{EPM}^{2}$} & \multicolumn{2}{|c|}{$P^{3}$} \\
\hline & $\mathrm{C}$ & GS & $\mathrm{CA}$ & & $\mathrm{C} 1$ & $\mathrm{C} 2$ \\
\hline \multicolumn{7}{|c|}{ Consumo } \\
\hline $\mathrm{EB}^{4}(\mathrm{Mcal} / \mathrm{dia})$ & 93,69 & 92,30 & 91,70 & 1,41 & 0,334 & 0,764 \\
\hline $\mathrm{ED}^{5}$ (Mcal/dia) & 62,45 & 62,53 & 61,72 & 1,43 & 0,851 & 0,690 \\
\hline $\mathrm{EM}^{6}$ (Mcal/dia) & 51,83 & 51,89 & 51,24 & 1,18 & 0,865 & 0,697 \\
\hline $\mathrm{EL}^{7}(\mathrm{Mcal} / \mathrm{dia})$ & 40,86 & 41,70 & 38,09 & 0,61 & 0,205 & 0,002 \\
\hline \multicolumn{7}{|c|}{ Exigência } \\
\hline $\mathrm{EL}_{\mathrm{L}}^{8}(\mathrm{Mcal} / \mathrm{dia})$ & 22,54 & 23,42 & 23,53 & 0,76 & 0,318 & 0,919 \\
\hline $\begin{array}{l}\mathrm{EL}_{\mathrm{M}}{ }^{9} \\
\text { (Mcal/dia) }\end{array}$ & 9,55 & 9,57 & 9,56 & 0,03 & 0,756 & 0,733 \\
\hline \multicolumn{7}{|c|}{ Balanço de energia } \\
\hline $\left.\mathrm{EL}^{10} \mathrm{Mcal} / \mathrm{dia}\right)$ & 8,77 & 8,67 & 5,01 & 0,84 & 0,074 & 0,040 \\
\hline \multicolumn{7}{|c|}{ Eficiência energética } \\
\hline $\mathrm{EL}_{\mathrm{L}} / \mathrm{CED}$ & 0,38 & 0,36 & 0,38 & 0,06 & 0,245 & 0,900 \\
\hline \multirow{3}{*}{\multicolumn{7}{|c|}{$\begin{array}{l}\text { 1Controle (C); grão de soja (GS); caroço de algodão (CA); } 2 \text { Erro padrão da média;3 } \\
\text { Contrastes ortogonais: Controle vs semente oleaginosa }(\mathrm{C} 1) \text {; grão de soja vs caroço de } \\
\text { algodão }(\mathrm{C} 2) ; 4 \text { Consumo de Energia Bruta }(\mathrm{CEB}) ; 5 \text { Consumo de Energia Digestivel } \\
\text { (CED); } \\
6 \text { Consumo de Energia Metabolizada }(\mathrm{CEM}) ; \\
7 \text { ELL }(\text { consumo })=0.703 \times \text { EM }(\text { Consumo })-0.19+\{[(0.097 \times \text { EM }(\text { Consumo })+ \\
0.19) / 97] \times[\mathrm{EE}-3]\} ; \text { EM }(\text { Consumo })=1.01 \times(\mathrm{ED}(\text { consumo }))-0.45]+0.0046 \times(\mathrm{EE}- \\
\text { 3) }(\text { NRC }, 2001) ;\end{array}$}} \\
\hline & & & & & & \\
\hline & & & & & & \\
\hline \multicolumn{7}{|c|}{$\begin{array}{l}8 \text { ELL para produção de leite }(\text { Mcal/dia })=\text { Produção de leite }(\mathrm{Kg}) \times(0.0929 \times \mathrm{G} \%+ \\
0.0563 \times \text { proteína verdadeira } \%+0.0395 \times \text { lactose } \%)(\mathrm{NRC}, 2001) .\end{array}$} \\
\hline $9 \mathrm{ELM}=0,08 * \mathrm{PV} 0$ & & & & & & \\
\hline
\end{tabular}

As vacas alimentadas com grão de soja apresentaram maior consumo de energia líquida, levando a um maior balanço de energia, o que pode ser interessante, dependendo da condição de escore corporal do rebanho. Considerando que o escore de condição corporal médio dos animais experimentais foi cerca de $3 \pm 0,25$, e segundo o NRC (2001), são necessários cerca de 460 Mcal para que uma vaca ganhe uma unidade de ECC quando nesta condição. Sendo assim, as vacas recebendo grão de soja serão necessários aproximadamente 53 dias para o ganho de um escore de condição corporal (balanço energético médio de 8,67 
Mcal/dia) enquanto os animais alimentados com caroço de algodão precisariam de aproximadamente 91 dias (balanço energético de 5,01 Mcal/dia).

\subsection{BALANÇO DE NITROGÊNIO}

Os resultados obtidos para o consumo de compostos nitrogenados totais (NT), a excreção de compostos nitrogenados nas fezes ( $\mathrm{N}$-fecal), na urina $(\mathrm{N}$-urina) e no leite $(\mathrm{N}$ leite), o balanço de nitrogênio (BN) e a eficiência de utilização de nitrogênio obtidas para as dietas são apresentados na (Tabela 9).

Não foi observado efeito para consumo de nitrogênio total entre os animais tratados com dieta $\mathrm{C}$ e os que consumiram sementes oleaginosas, enquanto que entre as dietas com suplementação de sementes oleaginosas houve efeito $(\mathrm{P}<0,05)$, com aumento médio na ingestão de 48,2 gramas de NT por dia pelos animais que se alimentaram com dietas contendo GS em relação aos tratados com CA. Este aumento de $8 \%$ na ingestão de nitrogênio dos animais tratados com GS é relativo aos 280 gramas a mais de consumo médio diário de PB $(\mathrm{P}<0,05)($ Tabela 4$)$ dos animais alimentados com esta dieta.

Analisando a excreção fecal de nitrogênio não foi encontrada diferença entre as dietas que tiveram inclusão de sementes oleaginosas e a dieta controle. Entre os animais alimentados com sementes observou-se média de 25,0 gramas de nitrogênio a mais nas fezes das vacas alimentadas com a dieta GS em relação aos animais alimentados com a dieta CA. Esta diferença de 15,0 \% se deve a maior ingestão de PB (P<0,05) (Tabela 4) desses animais. Para a excreção de compostos nitrogenados totais, na urina (N-urina) e no leite (N-leite) não houve efeito das dietas tanto quando analisamos $\mathrm{C} 1$ quanto $\mathrm{C} 2$. A excreção de nitrogênio no leite está diretamente relacionada com a produção de proteína no leite (Tabela 7) que não foi afetada neste estudo, resultados semelhantes aos de Venturelli (2011) que avaliou os efeitos de diferentes teores de grão de soja cru e integral na alimentação de vacas leiteiras no terço final de lactação. 
Tabela 9 - Balanço de nitrogênio de vacas lactantes alimentadas com inclusão de sementes oleaginosas ou não

\begin{tabular}{|c|c|c|c|c|c|c|}
\hline \multirow{2}{*}{ Variáveis } & \multicolumn{3}{|c|}{ Dietas experimentais ${ }^{1}$} & \multirow{2}{*}{$\mathrm{EPM}^{2}$} & \multicolumn{2}{|c|}{$P^{3}$} \\
\hline & $\mathrm{C}$ & GS & $\mathrm{CA}$ & & $\mathrm{C} 1$ & $\mathrm{C} 2$ \\
\hline \multicolumn{7}{|c|}{ Consumo (g/dia) } \\
\hline $\begin{array}{l}\text { Nitrogênio } \\
\text { Total }\end{array}$ & 650,07 & 654,54 & 605,97 & 11,60 & 0,110 & 0,001 \\
\hline \multicolumn{7}{|c|}{ Excreção (g/dia) } \\
\hline Fecal & 200,49 & 205,03 & 175,93 & 5,55 & 0,210 & 0,003 \\
\hline Urinário & 215,6 & 197,44 & 190,95 & 6,80 & 0,082 & 0,641 \\
\hline Leite & 154,03 & 159,22 & 150,97 & 3,26 & 0,766 & 0,052 \\
\hline \multicolumn{7}{|c|}{ Balanço (g/dia) } \\
\hline Nitrogênio & 79,94 & 92,85 & 88,11 & 4,96 & 0,278 & 0,671 \\
\hline \multicolumn{7}{|c|}{ Excreção (\% Nitrogênio Total) } \\
\hline Fecal & 30,76 & 31,16 & 29,00 & 0,61 & 0,565 & 0,118 \\
\hline Urinário & 32,93 & 30,16 & 32,51 & 0,77 & 0,288 & 0,180 \\
\hline Leite & 23,83 & 24,50 & 23,83 & 0,45 & 0,149 & 0,502 \\
\hline \multicolumn{7}{|c|}{ Balanço (\% Nitrogênio Total) } \\
\hline Nitrogênio & 13,47 & 14,16 & 13,47 & 0,66 & 0,292 & 0,642 \\
\hline
\end{tabular}

\section{Porcentagem}

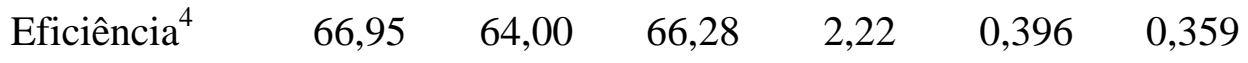

${ }^{1}$ Controle (C); grão de soja (GS); caroço de algodão (CA); ${ }^{2}$ Erro padrão da média; ${ }^{3}$ Contrastes ortogonais: Controle vs semente oleaginosa (C1); grão de soja vs caroço de algodão (C2); ${ }^{4} \%$ de $\mathrm{N}$ consumido não excretado nas fezes e urina e secretado no leite.

O balanço de nitrogênio teve média de 85,85 g/dia, ou seja, 13,14 \% NT, e não apresentaram efeito das dietas experimentais. Tal resultado pode estar relacionado ao alto consumo de proteína bruta (média de 3,98 kg/dia) e a fase de lactação dos animais. Spanghero e Kowalski (1997) realizaram compilação de dados através de meta-análise, considerando 35 experimentos e 135 dietas diferentes, com média de CMS de 17,6 Kg/dia, e produção média de leite de 26,1 Kg/dia. Estes autores avaliaram o balanço de nitrogênio em vacas leiteiras e verificaram valores médios de balanço de nitrogênio de 39,0 g/dia. 
Alguns autores como Jenkins (1993) relatam que a inclusão de lipídeos acima do considerado basal (3,0\% na MS da dieta) pode interferir no metabolismo de nitrogênio no rúmen. Holter et al. (1992), analisaram a inclusão de 15,0 \% de caroço de algodão com ou sem a adição de sais de cálcio de ácidos graxos na alimentação de vacas raça Holandesa, relataram que o balanço de nitrogênio não foi a alterado pela suplementação lipídica, mesmo com dietas contendo até 6,76 de EE na MS, uma inclusão 31,0 \% maior que este ensaio.

O consumo de nitrogênio entre as dietas experimentais é reflexo do CMS (Tabela 4), e às concentrações de ureia no soro (Tabela 10). Isso justifica a variação no consumo e excreção fecal de nitrogênio (g/dia), já que as dietas utilizadas neste estudo foram isonitrogenadas.

Independentemente das dietas experimentais, não foi verificado animais com balanço de $\mathrm{N}$ negativo, o que sugere que o consumo de proteína atendeu as exigências proteicas dos animais.

\subsection{METABOLITOS SANGUÍNEOS}

As vacas alimentadas com dietas com inclusão de sementes de oleaginosas tiveram em media 44,68 mg/dL a mais de colesterol total e 9,66 mg/dL de colesterol HDL (Tabela 10) que os animais alimentados com dieta controle $(\mathrm{P}<0,05)$. Entretanto não houve diferença entre as vacas alimentadas com sementes de oleaginosas para colesterol total (Tabela 10). Este aumento da concentração do colesterol HDL no lipidograma do soro pode ser justificado devido ao maior consumo de lipídeos pelos animais alimentados com dietas contendo sementes oleaginosas $(\mathrm{P}<0,05)$ (Tabela 4), que proporcionou aumento das respectivas frações relativas ao metabolismo de lipídios transportados no sangue. Hawkins et al. (1985) em estudos com inclusão de caroço de algodão (15,3\% MS) e Mohamed (1988) com uso de grão de soja (16,5\% MS), observaram que a quantidade de triglicerídeos foi maior nos animais recebendo sementes oleaginosas em relação a dieta controle.

A maior concentração de colesterol HDL foi encontrada no sangue das vacas alimentadas com dieta GS, com um aumento médio de $0,16 \mathrm{mg} / \mathrm{dL}$ representando $16 \%$ a mais de colesterol HDL em relação aos animais que se alimentaram com dieta CA. 
Tabela 10 - Metabólitos plasmáticos de vacas lactantes alimentadas com inclusão de sementes oleaginosas ou não

\begin{tabular}{|c|c|c|c|c|c|c|}
\hline \multirow{2}{*}{ Parâmetros } & \multicolumn{3}{|c|}{$\operatorname{Dietas}^{1}$} & \multirow{2}{*}{$\mathrm{EPM}^{2}$} & \multicolumn{2}{|c|}{$P^{3}$} \\
\hline & $\mathrm{C}$ & GS & $\mathrm{CA}$ & & $\mathrm{C} 1$ & $\mathrm{C} 2$ \\
\hline & & $M g / d l$ & & & & \\
\hline Glicose & 84,85 & 80,06 & 77,87 & 2,97 & 0,823 & 0,315 \\
\hline Colesterol & 96,34 & 143,37 & 132,48 & 4,79 & $<0,001$ & 0,267 \\
\hline C-HDL & 0,71 & 1,14 & 0,98 & 0,03 & $<0,001$ & 0,002 \\
\hline Ureia & 38,99 & 36,74 & 40,22 & 1,67 & 0,869 & 0,340 \\
\hline & & $g / L$ & & & & \\
\hline Proteinas totais & 5,04 & 4,98 & 4,75 & 0,08 & 0,273 & 0,230 \\
\hline Albumina & 2,31 & 2,37 & 2,32 & 0,07 & 0,718 & 0,693 \\
\hline & & $U / L$ & & & & \\
\hline AST & 61,03 & 60,20 & 54,59 & 1,40 & 0,622 & 0,172 \\
\hline GGT & 5,50 & 5,28 & 5,79 & 0,19 & 0,895 & 0,138 \\
\hline
\end{tabular}

${ }^{1}$ Controle (C); grão de soja (GS); caroço de algodão (CA); 2 Erro padrão da média;3 Contrastes ortogonais: Controle vs semente oleaginosa (C1); grão de soja vs caroço de algodão (C2);

Este aumento é reflexo do maior consumo $\mathrm{EE}(\mathrm{P}<0,05)$ dos animais que alimentados com dieta GS em relação à dieta contendo CA $(\mathrm{P}<0,05)$ (Tabela 4). Este mesmo efeito do aumento no consumo de EE nesses parâmetros sanguíneos são relatados por Barletta (2010) com inclusões de GS na dieta de vacas da raça Holandesas no terço médio de lactação, onde foi observado maior valor para a dieta com maior inclusão de grão de soja $(24,0 \%)$ sendo 1,32 vezes o valor médio deste parâmetro do que quando as vacas foram alimentadas com dieta C. Resultados parecidos, foram observados por Venturelli (2011) com 33\% mais colesterol e $22 \%$ mais C-HDL nos animais que consumiram a dieta com maior inclusão da semente $(27,0 \%)$ em relação a dieta controle.

Não foi observada diferença nas concentrações plasmáticas de glicose, proteínas totais e albumina. Do mesmo modo, Belibasakis e Tsirgogianni (1995) não encontram diferença na concentração de glicose no plasma sanguíneo $(61 \mathrm{mg} / \mathrm{dL})$ e proteína total (9 $\mathrm{mg} / \mathrm{dL}$ ) quando foi incluído $20,0 \%$ de CA na dieta das vacas em lactação. De maneira parecida, suplementando com 17,0 a 34,0\% de CA na dieta, tendo cana de açúcar como fonte volumosa, Martinez (2008) não encontrou diferença nos níveis plasmáticos de glicose (68 $\mathrm{mg} / \mathrm{dL}$ ). Usando 16,5\% (MS) de GS, Mohamed (1988) também não encontrou diferença na 
concentração de glicose sanguínea entre os tratamentos contendo caroço de algodão e a dieta controle.

Os metabólitos plasmáticos tiveram suas concentrações alteradas pelas dietas com inclusão de sementes, especialmente o colesterol total e HDL. Entretanto, a inexistência de variações das enzimas hepáticas AST e GGT, indicam que neste estudo os animais em lactação suplementados com sementes no nível de até 12,0 \% de inclusão na MS da dieta, não sofreram alterações consideráveis no tecido hepático durante o metabolismo dos lipídeos mostrando assim, potencial de uso destas sementes oleaginosas sem alterar a saúde dos animais. 


\section{CONCLUSÃo}

A substituição parcial do fubá de milho e farelo de soja, tanto pelo caroço de algodão, quanto pelo grão de soja cru e integral, no teor de $12 \%$ da MS da dieta de vacas no terço médio de lactação, e com produção de cerca de $30 \mathrm{~L} /$ dia, não alterou o desempenho produtivo destes animais. 


\section{REFERÊNCIAS}

ABEL-CAINES, S. F.; GRANT, R. J.; KLOPFENSTEIN, T. J. Influence of nonenzymatically browned soybeans on ruminal fermentation and lactational performance of dairy cows. Journal of Dairy Science, v. 81, p. 1036-1045, 1997

ABUGHAZALEH, A. A.; SCHINGOETHE, D. J.; HIPPEN, A. R. Fatty acid profiles of milk and rumen digesta from cows fed fish oil, extruded soybeans or their blend. Journal of Dairy Science, v. 85 , p. 2266-2276, 2002

ALLEN, M. S. Effects of diet on short-term regulation of feed intake by lactating dairy cattle. Journal of Dairy Science, v. 83, n. 7, p. 1598-1630, 2000.

ANDERSON, M. J.; ADAMS, D. C.; LAMB, R. C. Feeding whole cottonseed to lactating dairy cows. Journal Dairy Science, v. 62, p. 1098-1103, 1979.

ARIELI, A. Whole cottonseed in dairy cattlefeeding: a review. Animal Feed Science Technology, v. 72, p. 97-110, 1998.

BARLETTA, R. V. Grão de soja cru e integral na alimentação de vacas leiteiras. 2010.96 f. Dissertação (Mestrado em Ciências) - Faculdade de Medicina Veterinária e Zootecnia, Universidade de São Paulo, Pirassununga, 2010.

BAIER, A. C.; ROMAN, E. S. Informações sobre a cultura da canola para o sul do Brasil. In: SEMINÁRIO ESTADUAL DE PESQUISA DE CANOLA, 1., 1992, EMBRAPA/CNPT Passo Fundo. 1992. $10 \mathrm{p}$

BAUMAN, D. E.; GRIINARI, J. M. Regulation and nutritional manipulation of milk fat: low-fat milk syndrome. Livestock Production Science, v. 70, p. 15-29, 2001

BAUMGARD, L. H.; MATITASHVILI, E.; CORL, B. A. trans-10, cis-12 Conjugated linoleic acid decreases lipogenic rates and expression of genes involved in milk lipid synthesis in dairy cows. Journal of Dairy Science, v. 85, p. 2155-2163, 2002.

BELIBASAKIS, N. G.; TSIRGOGIANNI, D. Effect of whole cottonseed on milk yield, milk composition, and blood components of dairy cows in hot weather. Animal Feed Science Technology, v. 52, p. 227-235, 1995.

BERNARD, J. K. Effect of raw or roasted whole soybeans on digestibility of dietary nutrients and milk production of lactating dairy cows. Journal of Dairy Science, v. 73, n. 11, p. 3231-3236, 1990.

BERCHIELLI, T. T.; PIRES, A. V.; OLIVEIRA, S. G. Nutrição de ruminantes. Jaboticabal: Funep, 2006. $583 \mathrm{p}$.

BIGGS, H. G.; COOPER, J. M. An evaluation of four methods of measuring urinary creatinine.

Clinical Chemistry, v. 7, p. 665-673, 1961

BITMAN, J.; WOOD, D. L.; MILLER, R. H.; TYRRELL, H. F.; REYNOLDS, C. K.; BAXTER, H. D. Comparison of milk and blood lipids in Jersey and Holstein cows fed total mixed rations with or without whole cottonseed. Journal of Dairy Science, v. 79, p. 1596-1602, 1996. 
BRODERICK, G. A.; KERKMAN, T. M.; SULLIVAN, H. M.; DOWD, M. K. Effect of replacing soybean meal protein with protein from upland cottonseed, Pima cottonseed, or extruded Pima cottonseed on production of lactating dairy cows. Journal of Dairy Science, v. 96, p. 2374-2386, 2013.

CASALI, A. O.; DETMANN, E.; VALADARES FILHO, S. C.; PEREIRA, J. C.; HENRIQUES, L. T.; FREITAS, S. G.; PAULINO, M. F. Influência do tempo de incubação e do tamanho de partículas sobre os teores de compostos indigestíveis em alimentos e fezes bovinas obtidos por procedimentos in situ. Revista Brasileira de Zootecnia, v. 37, n. 2, p. 335-342, 2008.

CHEN, X. B.; GOMES, M. J. Estimation of microbial protein supply to sheep and cattle based on urinary excretion of purine derivatives - an overview of technical details. Bucksburnd, Aberdeen: International Feed Research Unit; Rowett Research Institute, 1992. 21 p.

CHIZZOTTI, M. L. Avaliação da casca de algodão para novilhos de origem leiteira e determinação da excreção de creatinina e produção de proteína microbiana em novilhas e vacas leiteiras. 2004. 132 p. Dissertação (Mestrado em Zootecnia) - Universidade Federal de Viçosa, Viçosa, 2004.

CHOUINARD, P. Y.; GIRARD, V.; BRISSON, G. J. Performance and profiles of milk fatty acids of cows fed full fat, heat-treated soybeans using various processing methods. Journal of Dairy Science, v. 80, p. 334-342, 1997.

CHRISTENSEN, R. A.; CAMERON, M. R.; CLARK, J. H.; DRACKLEY, J. K.; LYNCH, J. M.; BARBANO, D. M. Effects of amount of protein and ruminally protected amino acids in the diet of dairy cows fed supplemental fat. Journal of Dairy Science, v. 77, p. 1618-1629, 1994.

CLARK, P. W.; ARMENTANO, L. E. Effectiveness of neutral detergent fiber in whole cottonseed and dried distillers grains compared with alfafa haylage. Journal of Dairy Science, v. 76, p. 26442650, 1993.

CLARK, J. H.; KLUSMEYER, T. H.; CAMERON, M. R. Microbial protein syntesis and flows of nitrogen fractions to the duodenum of dairy cows. Journal of Dairy Science, v. 75, p. 2304-2323, 1992.

COELHO, D. T.; ROCHA, J. A. A. Práticas de processamento de produtos animais. Viçosa, MG: Universidade Federal de Viçosa, 1977. 79 p.

COPPOCK, C. E.; WILKS, D. L. Milk yield, and composition supplemental fat in high- energy rations for lactating cows: effects on intake, digestion. Journal Animal Science, v. 69, p. 3826-3837, 1991

COPPOCK, C. E.; WEST, J. W.; MOYA, J. R.; NAVE, D. H.; LABORE, J. M.; THOMPSON, K. G.; ROWE JR., L. D.; GATES, C. E. Effects of amount of whole cottonseed on intake, digestibility, and physio- logical responses of dairy cows. Journal of Dairy Science, v. 68, p. 2248-2258, 1985.

COPPOCK, C. E.; LANHAM, J. K.; HORNER, J. I. A review of the nutritive value and utilization of whole cottonseed, cottonseed meal and associated by-products by dairy cattle. Animal Feed Science and Techinnology, Amsteram, v. 18, p. 80-129, 1987.

COSTA, D. A.; CARNEIRO, J. C.; GAMA, S. A. M.; FERRAZ, F. C.; SALIBA, E. O. S.; REBOUÇAS, G. M. N. Produção e composição do leite de vacas submetidas à dieta contendo diferentes níveis de caroço de algodão. Semina: ciências agrárias, Londrina, v. 32, p. 2001-2010, 2011. Suplemento, 1.

DAVIS, R. N.; HARLAND, F. G. The effect of cottonseed in the ration on percentage of fat and serum solids content of milk. Journal of Dairy Science, v. 29, p. 829, 1946. 
DERESZ, F.; FERNANDES, A. M.; MATOS, L. L. Utilização da soja-grão crua na alimentação de vacas leiteiras de alta produção. Revista Brasileira de Zootecnia, v. 25, n. 1, p. 113-124, 1996.

DUNKLEY, W. L.; SMITH, N. E.; FRANKE, A. A. Effects of feeding protected tallow oncomposition composition of milk and milk fat. Journal of Dairy Science, v. 60, p. 1863, 1977.

ERWIN, E. S.; MARCO, G. J.; EMERY, E. M. Volatile fatty acid analyses of blood and rumen fluid by gas chromatography. Journal of Dairy Science, v. 44, n. 9, p. 1768-1777, 1961.

FALDET, M. A.; SATTER, L. D. Feeding heat-treated full fat soybeans to cows in early lactation. Journal of Dairy Science, v. 74, p. 3047-3054, 1991.

FERNANDES, J. J. R.; VAZ PIRES, A.; SANTOS, F. A. P.; SUSIN, I.; JOSÉ MANUEL SIMAS, J. M. C. Teores de caroço de algodão em dietas contendo silagem de milho para vacas em lactação. Acta Scientiarum, v. 24, n. 4, p. 1071-1077, 2002.

FREITAS JÚNIOR, J. E.; RENNÓ, F. P.; SILVA, L. F. P.; GANDRA, J. R.; MATURANA FILHO, M.; FODITSCH, C.; VENTURLLI, B. C. Parâmetros sanguíneos de vacas leiteiras suplementadas com diferentes fontes de gordura. Ciência Rural, v. 40, n. 4, p. 950-956, 2010.

FUJIHARA, T.; ØRSKOV, E. R.; REEDS, P. J. The effect of protein infusion on urinary excretion of purine derivatives in ruminants nourished by intragastric nutrition. Journal of Agricultural Science, v. 109, v. 1, p. 7-12, 1987.

FURLAN, R. L.; MACARI, M.; FARIA FILHO, D. E. Anatomia e fisiologia do trato gastrintestinal. In: BERCHIELLI, T. T. (Ed.) Nutrição de ruminantes. Jaboticabal: FUNEP, 2006. 583 p.

GONZÁLEZ-RONQUILLO, M.; BALCELLS, J.; GUADA, J. A. Purine derivative excretion in dairy cows: Endogenous excretion and the effect of exogenous nucleic acid supply. Journal of Dairy Science, v. 86, n. 4, p. 1282-1291, 2003.

GRUMMER, R. R.; HOFFMAN, P. C.; LUCK, M. L.; BERTICS, S. J. Effect of prepartum and postpartum dietary energy on growth and lactation of primiparous cows. Journal of Dairy Science, $v$. 78, p. 172-180, 1995

HALL, M. B. Making nutritional sense of nonstructural carbohydrate. In: ANNUAL FLORIDA RUMINANT NUTRITION SYMPOSIUM, 9., 1998, Gainsville, Fl. Proceedings... Gainsville: Florida University Press, 1998. p. 108-121.

HARVATINE, D. I.; FIRKINS, J. L.; EASTRIDGE, M. L. Whole linted cottonseed as a forage substitute fed with ground or steam-flaked corn: digestibitity and performance. Journal of Dairy Science, v. 85, p. 1976-1987, 2002.

HARVATINE, K. J.; ALLEN, M. S. Effects of Fatty Acid Supplements on Milk Yield and Energy Balance of Lactating Dairy Cows. Journal of Dairy Science, v. 89, p. 1081-1091, 2006.

HAWKINS, G. E.; CUMMINS, K. A.; SILVEIO, M.; JILEK, J. J. Physiological effects of whole cottonseed in the diet of lactating dairy cows. Journal of Dairy Science, v. 68, n.10, p. 2608-2614, 1985

HORNER, J. L.; WINDLE, L. M.; COPPOCK, C. E.; LABORE, J. M.; LANHAM, J. K. Effects of Whole Cottonseed, Niacin, and Niacinamide on In Vitro Rumen Fermentation and on Lactating Holstein Cows . Journal of Dairy Science, v. 71, p. 3334-3344, 1988.

JENKINS, T. C.; JENNY. B. F. Effects of hydrogenated fat on feed intake, nutrient digestibility of dairy cows. Journal Dairy Science, Savoy, v. 72, p. 2316-2321, 1989. 
JENKINS, T. C. Lipid metabolism in the rumen. Journal of Dairy Science, v. 76, p. 3851-3863, 1993.

KAJIKAWA, H.; ODAI, M.; SAITOH, M.; ABE, A. Effect of whole cottonseed on ruminal properties and lactation performance of cows with different rumen fermentation patterns. Animal Feed Science and Technology, Amsterdam, v. 34, p. 203-212, 1991.

LEHNINGER, A. L. Princípios de bioquímica. 3. ed. Barcelona: Saevier, 2005.

LENG, R. A.; NOLAN, J. V. Nitrogen metabolism in the rumen. Journal of Dairy Science, v. 67, n. 5, p. 1072-1089, 1984.

LENG, R. A. Factors affecting the utilization of "poor-quality" forages by ruminants particularly under tropical conditions. Nutrition Research Review's, v. 3, p. 277-303, 1990.

LUBIS, D.; VAN HORN, H. H.; HARRIS JR., B.; K. C. BACHMAN, S. M. EMANUELE Responses of lactating dairy cows to protect fats or whole cottonseed in low or high forage diets. Journal of Dairy Science, v. 73, p. 3512, 1990.

MARTINEZ, J. C. Avaliação de co-produtos na alimentação de vacas leiteiras mantidas em pastagens tropicais durante a estação chuvosa e alimentadas no cocho durante a estação seca do ano. 2008. 76 p. Tese (Doutorado) - Escola Superior de Agricultura Luiz de Queiroz, Universidade de São Paulo, Piracicaba, 2008.

McDONALD, P. M.; EDWARDS, R. A.; GREENHALGH, J. F. D.; MORGAN, C. A. Animal nutrition. Harlow, UK: Pearson, 2002. 693 p.

MEHREZ, A. Z.; ORSKOV, E. R.; McDONALD, I. Rates of rumen fermentation in relation to ammonia concentration. British Journal of Nutrition, v. 38, p. 437-443, 1977.

MELO, A. A. S.; FERREIRA, M. A.; CHAVES, A. S. Caroço de algodão em dietas à base de palma forrageira para vacas leiteiras: síntese de proteína microbiana. Revista Brasileira de Zootecnia, v. 36, n. 4, p. 912-920, 2007.

MELO, A. A. S. de; FERREIRA, M. A.; VÉRAS, A. S. C.; LIRA, M. A.; LIMA, L. E. de; PESSOA, R. A. S.; BISPO, S. V.; CABRAL, A. M. D.; AZEVEDO, M. de. Desempenho leiteiro de vacas alimentadas com caroço de algodão em dieta à base de palma forrageira. Pesquisa Agropecuária Brasileira, Brasília, v. 41, n. 7, p. 1165-1171, 2006.

MERTENS, D. R. Gravimetric determination of amylase-treated neutral detergent fibre in feeds with refluxing beakers or crucibles: collaborative study. Journal of AOAC International, v. 85, p. 12171240, 2002.

MIELKE, C. D.; SHINGOETHE, D. J. Heat-treated soybeans for lactating cows. Journal of Dairy Science, v. 64, p. 1579, 1981.

MOHAMED, O. E.; SATTER, L. D.; GRUMMER, R. R.; EHLE, F. R. Influence of dietary cottonseed and soybean on milk production and composition Journal of Dairy Science, Champaign, v. 71, n. 10, p. 2677-2688, 1988.

MOORE, J. A.; SWINGLE, R. S.; HALE, W. H. Effects of whole cottonseed, cottonseed oil or animal fat on digestibility of wheat straw diets by steers. Journal of Dairy Science, Champaign, v. 63, n. 4, p. 1267-1273, 1986.

MORA, P. J. G.; LEÃO, M. I.; VALADARES FILHO, S. C.; Grãos de soja em rações para vacas lactantes: consumo dos nutrientes, produção e composição do leite. Revista Brasileira de Zootecnia, Viçosa, v. 25, n. 2, p. 369-381, 1996. 
NRC. NATIONAL RESEARCH COUNCIL. Nutrient requirements of dairy cattle. 7. ed. Washinton, D.C.: National Academic Press. 2002. 381 p.

NEVES, C. A.; SANTOS, G. T.; MATSUSHITA, M.; Intake, whole tract digestibility, milk production, and milk composition of Holstein cows fed extruded soybeans treated with or without lignosulfonate. Animal Feed Science Technology, v. 134, p. 32-44, 2007.

NOCEK, J. E. In situ and other methods to estimate ruminal protein and energy digestibility. A review. Journal of Dairy Science, v. 71, p. 2051-2069, 1988

OLIVEIRA, A. S.; VALADARES, R. F. D.; FILHO, S. C. V.; CECON, P. R.; RENNÓ, L. N.; QUEIROZ, A. C.; CHIZZOTTI, M. L. Produção de proteína microbiana e estimativas das excreções de derivados de purinas e de uréia em vacas lactantes alimentadas com rações isoprotéicas contendo diferentes níveis de compostos nitrogenados não-proteicos. Revista Brasileira de Zootecnia, v. 30, n. 5, p. 1621-1629, 2001.

ORELLANA BOERO, P.; BALCELLS, J.; MARTÍN-ORÚE, S. M. Excretion of purine derivates in cows: endogenous contribution and recovery of exogenous purine bases. Livestock Production Science, v. 68, p. 243-250, 2001.

PALMQUIST, D. L.; CONRAD, H. R. High fat rations for dairy cows. Effects on feed intake, milk and fat production, and plasma metabolites. Journal of Dairy Science, v. 61, p. 890, 1978.

PALMQUIST, D. L.; CONRAD, H. R. High fat rations for dairy cows. Tallow and hydrolyzed blended fat at two intakes. Journal of Dairy Science, v. 63, p. 391-402, 1980.

PALMQUIST, D. L.; CONRAD, H. R. Influence of source and amount of dietary fat on digestibility in lactating cows. Journal of Dairy Science, v. 74, p. 1354-1360, 1991.

PALMQUIST, D. L.; WEISBJERG, M. R.; HVELPLUND, T. Ruminal, intestinal, and total digestibilities of nutrients in cows fed diets high in fat and undegradable protein. Journal of Dairy Science, v. 76, p. 1353-1364, 1993.

PALMQUIST, D. L.; MATTOS, W. R. S. Metabolismo de lipídeos. In: BERCHIELI, T. T.; PIRES, A. V.; OLIVEIRA, S. G. (Ed.). Nutrição de ruminantes. Jaboticabal: FUNEP, 2006. p. 287-310.

PETIT, H. V. Digestion, milk production, milk composition, and blood composition of dairy cows fed whole flaxseeds. Journal of Dairy Science, v. 85, p. 1482-1490, 2002.

PETIT, H. V.; GERMIQUET, C.; LEBEL, D. Effect of feeding whole, unprocessed sunflower seeds and flaxseed on milk production, milk composition, and prostaglandin secretion in dairy cows.

Journal of Dairy Science, v. 87, p. 3889-3898, 2004.

PETIT, H. V.; PALIN, M. F.; DOEPEL, L. Hepatic lipid metabolism in transition dairy cows fed flaxseed. Journal of Dairy Science, v. 90, p. 4780-4792, 2007.

PIRES, A. V.; EASTRIDGE, M. L.; FIRKINS, J. L. Roasted soybeans, blood meal, and tallow as sources of fat and ruminally undegradable protein in the diets of lactating cows. Journal of Dairy Science, v. 79, p. 1603-1610, 1996.

O'CONNOR, J. D.; SNIFFER, C. J.; FOX, D. G. A NET. Carbohydrate and protein system for evaluating cattle diets: iv predicting amino acid adequacy. Journal of Dairy Science, v. 71, p. 12951311, 1993. 
ONETTI, S. G.; GRUMMER, R. R. Response of lactating cows to three supplemental fat sources as affected by forage in the diet and stage of lactation: a meta-analysis of literature. Animal Feed Science and Technology, v. 115, p. 65-82, 2004.

RABELLO, T. M.; VALADARES FILHO, S. C.; COELHO DA SILVA, J. F. Grão de soja moído na alimentação de vacas em lactação. Consumo, produção e composição do leite. Revista Brasileira de Zootecnia, v. 25, n. 2, p. 345-356, 1996.

RENNÓ, F. P.; FREITAS JÚNIOR, J. E.; GANDRA, J. F. R.; BARLETTA, R. V.; NAVES, A. B.; GAMEIRO, A. H.; VERDURICO, L. C. Grão de soja na alimentação de vacas leiteiras. In: SANTOS, M. V.; RENNÓ, F. P.; SILVA, L. F. P.; ALBUQUERQUE, R. Novos desafios da pesquisa em nutrição e produção animal. Pirassununga: Ed. 5D, 2009. v. 1, p. 191-214.

RENNÓ, L. N. Consumo, digestibilidade total e parcial, produção microbiana, parâmetros ruminais e excreções de uréia e creatinina em novilhos alimentados com dietas contendo quatro níveis de uréia ou dois de proteína. 2003. 252 p. Tese (Doutorado em Zootecnia) - Universidade Federal de Viçosa, Viçosa, 2003.

ROGÉRIO, M. C. P.; BORGES, I.; TEIXEIRA, D. A. B.; RODRIGUEZ, N. M.; GONÇALVES, L. C. Efeito do nível de caroço de algodão sobre a digestibilidade da fibra dietética do feno de Tifton 85 (Cynodon spp.) em ovinos. Arquivo Brasileiro de Medicina Veterinária e Zootecnia, v. 56, n. 5, p. 665-670, 2004.

RUSSELL, J. B.; O'CONNOR, J. D.; FOX, D. G. A net carbohydrate and protein system for evaluating cattle diets. I. Ruminal fermentation. Journal of Animal Science, Savoy, v. 70, p. 35513561, 1992.

SATTER, L. D.; SLYTER, L. L. Effect of ammonia concentration on rumen microbial production in vitro. British Journal of Nutrition, v. 32, n. 2, p. 199-208, 1974.

STANLEY, R. W.; COBB, E.; MORITA, K.; CARPENTER, J.; ISHIZUKI, J. The effect of feeding whole cottonseed to lactating dairy cattle on milk and fat production. Hawaii Agr. Exp. Sta. Res., v. 177, p. 1, 1969.

SPANGHERO, M. Z.; KOWALSKI, Z. M. Critical analysis of N balance experiments with lactating cows. Livestock Production Science, v. 52, p. 113-122, 1997.

SMITH, N. E.; COLLAR, L. S.; BATH, D. L.; DUNCKLEY, W. L.; FRANKE, A. A. Digestibility and effects of whole cottonseed fed to lactating cows.. Journal of Animal Science, v. 64, p. 2209$2215,1981$.

SMITH, W. A.; HARRIS, B.; VAN HORN JR., H. H.; WILCOX, C. J. Effects of forage type on production of dairy cows supplemented with whole cottonseed, tallow, and yeast. Journal of Dairy Science, v. 76, p. 205-215, 1993.

SNIFFEN, C. J.; O'CONNOR, J. D.; VAN SOEST, P. S.; FOX, D. G.; RUSSELL, J. B. A net carbohydrate and protein system for evaluating cattle diets. ii. carbohydrate and protein availability. Journal of Animal Science, v. 70, n. 11, p. 3562-3577, 1992

STERN, M. D.; ZIEMER, C. J. Digestible fiber sources for dairy cattle. 53rd MINNESOTA NUTRITION CONFERENCE, 53., 1992, Bloomington, MN. 1992. p. 37-56. 
SOUSA, P. D.; CAMPOS, J. M. S.; VALADARES FILHO, S. C. Parâmetros fermentativos, produção de proteína microbiana, concentrações de ureia no leite e no plasma e balanço de nitrogênio de vacas alimentadas com silagem de milho ou cana-de-açúcar com caroço de algodão. Revista Brasileira Zootecnia, v. 38, n. 10, p. 2063-2071, 2009.

SCOTT, T. A.; COMBS, D. K.; GRUMMER, R. R. Effects of roasting, extrusion, and particle size on the feeding value of soybeans for dairy cows. Journal of Dairy Science, v. 74, p. 25-55, 1991.

SKLAN, D.; ASHKENAZI, R.; BRAUN, A.; DEVORIN, A.; TABORI, K. Fatty acids, calcium soaps of fatty acids, and cottonseeds fed to high yielding cows. Journal of Animal Science, v. 75, p. 24632472, 1992.

SULLIVAN, H. M.; BERNARD, J. K.; AMOS, H. E.; JENKINS, T. C. Performance of lactating dairy cows fed whole cottonseed with elevated concentrations of free fatty acids in the oil. Journal of Animal Science, v. 87, p. 665-671, 2004.

VALADARES FILHO, S. C. Eficiência de síntese de proteína microbiana, degradação ruminal e digestibilidade intestinal da proteína bruta, em bovinos. In: SIMPÓSIO IN- TERNACIONAL SOBRE EXIGÊNCIAS NUTRICIONAIS DE RUMINANTES, 1995, Viçosa. Anais... Viçosa: DZO, 1995. p. 355-388.

VALADARES, R. F. D.; BRODERICK, G. A.; VALADARES FILHO, S. C. Effect of replacing alfafa with high moisture corn on ruminal protein synthesis estimated from excretion of total purine derivatives. Journal of Animal Science, v. 82, p. 2686-2696, 1999.

VALADARES FILHO, S. C.; ROCHA JUNIOR, V. R.; CAPPELLE, E. R. Tabelas brasileiras de composição de alimentos para bovinos. Viçosa: UFV, DZO, DPI, 2002. 297 p.

VALADARES FILHO, S. C.; MAGALHÃES, K. A.; ROCHA JÚNIOR, V. R. Tabelas brasileiras de composição de alimentos para bovinos. Viçosa: UFV, 2006. 29 p.

VAN DIJK, H. J.; O'DELL, G. D.; PERRY, P. R. Extruded versus raw ground soybeans for dairy cows in early lactation. Journal of Animal Science, v. 66, p. 2521-2525, 1983.

VAN SOEST, P. J.; MASON, V. C. The influence of Maillard reaction upon the nutritive value of fibrous feeds. Animal Feed Science and Technology, v. 32, n. 1, p. 45-53, 1991.

VAN SOEST, P. J. Nutritional ecology of the ruminant. 2. ed. Ithaca: Constock Publishing Associates, 1994. $476 \mathrm{p}$.

VASCONCELOS, A. M.; LEÃO, M. I.; VALADARES FILHO, S. C.; VALADARES, R. F. D.; DIAS, M.; MORAIS, D. A. E. F. Parâmetros ruminais, balanço de compostos nitrogenados e produção microbiana de vacas leiteiras alimentadas com soja e seus subprodutos. Revista Brasileira de Zootecnia, v. 39, n. 2, p. 425-433, 2010.

VENTURELLI, B. C. Grão de soja cru e integral na alimentação de vacas leiteiras no terço final de lactação. 2011. 103 f. Dissertação (Mestrado em Ciências) - Faculdade de Médicina Veterinária e Zootecnia, Universidade de São Paulo, Pirassununga, 2011.

VILELA, D.; ALVIM, M. J.; RESENDE, J. C. Produção de leite de vacas holandesas em confinamento ou em pastagem de coast-cross. Revista Sociedade Brasileira de Zootecnia, Viçosa, v. 25, n. 6, p. 1228-1244, 1996.

WILKS, D. L.; COPPOCK, C. E.; BROOKS, K. N.; GATES, C. E. Effect of differences in starch content of diets with whole cottonseed or rice bran on milk casein. Journal of Dairy Science, v. 74, p. 1314-1320, 1991. 
WU, Z.; HUBER, J. T.; CHAN, S. C.; SIMAS, J. M.; CHEN, K. H.; VARELA, J. G.; SANTOS, C.; FONTES JR., C.; YU, P. Effect of three supplemental fat sources on lactation and digestion in dairy cows. Journal of Animal Science, v. 76, p. 3562-3570, 1993.

WU, Z.; HUBER, J. T.; CHAN, S. C.; SIMAS, J. M.; CHEN, K. H.; VARELA, J. G.; SANTOS, C.; FONTES JR., C.; YU, P. Effect of source and amount of supplemental fat on lactation and digestion in cows. Journal of Dairy Science, v. 77, p. 1644-1651, 1994.

ZHANG, W. J.; XU, G. R.; PAN, X. L.; YAN, X. H.; WANG, Y. B. Advances in gossypol toxicity and processing effects of whole cottonseed in dairy cows feeding. Livestock Science, v. 11, p. 1-9, 2007. 